\title{
The Krásno Sn-W ore district near Horní Slavkov: mining history, geological and mineralogical characteristics
}

\author{
Sn-W rudní revír Krásno u Horního Slavkova - historie těžby, geologická \\ a mineralogická charakteristika
}

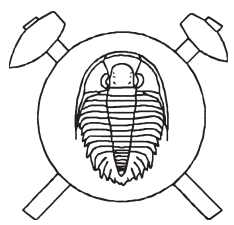

(47 figs, 1 tab)

\author{
PAVEL BERAN ${ }^{1}-$ JIŘÍ SEJKORA² \\ ${ }^{1}$ Regional Museum Sokolov, Zámecká 1, Sokolov, CZ-356 00, Czech Republic \\ ${ }^{2}$ Department of Mineralogy and Petrology, National Museum, Václavské nám. 68, Prague 1, CZ-115 79, Czech Republic
}

\begin{abstract}
The tin-tungsten Krásno ore district near Horní Slavkov (Slavkovský les area, western Bohemia) belongs to the most important areas of ancient mining in the Czech Republic. The exceptionally rich and variable mineral associations, and the high number of mineral species, make this area one of the most remarkable mineralogical localities on a worldwide scale. The present paper reviews the data on geological setting of the ore district, individual ore deposits and mining history. Horní Slavkov and Krásno were known as a rich source of exquisite quality mineral specimens stored in numerous museum collections throughout Europe. The old museum specimens are often known under the German locality names of Schlaggenwald (= Horní Slavkov) and Schönfeld (=Krásno). The megascopic properties and paragenetic position of selected "mineral classics" are reviewed which include arsenopyrite, fluorapatite, fluorite, hübnerite, chalcopyrite, carpholite, cassiterite, quartz, molybdenite, rhodochrosite, sphalerite, topaz and scheelite.
\end{abstract}

Key words: Sn-W ores; tin-tungsten mineralization; mining history; ore geology; mineralogy; Slavkovský les; Krásno, Horní Slavkov ore district; Czech Republic.

\section{Introduction}

In the mining history of Central Europe, Bohemia and Moravia are known as important source of gold, silver, tin, and iron. Later on, uranium and other metals were exploited. The medieval mining activities gave rise to several mining centres in the Kingdom of Bohemia such as Kutná Hora, Jílové near Praha (Prague), Jáchymov, Př́bram and also the Horní Slavkov - Krásno mining district (Fig. 1).

The Krásno district is located near Horní Slavkov in the Slavkovský les renowned in the past by rich deposits of tin, silver, bismuth, and uranium. The district is represented by mineralization in several granite cupolas of the large Krušné hory (Erzgebirge) granite batholith, underlying metamorphic rocks of the "Slavkov gneiss block". The Krásno district comprises several deposits, such as the Huber stock (Hub stock in some publications), Schnöd stock, Gellnauer elevation and the Gellnauer set of veins (Gellnau in some publications). It represents the most important concentrations of Sn-W ores in the Slavkovský les area.

\section{Topography}

The Krásno ore district is located at a distance of about $1 \mathrm{~km}$ of Krásno nad Teplou (old name Schönfeld) and 2 km of Horní Slavkov (old name Schlaggenwald) (Fig. 2). The ore district is located in the Slavkovský les elevated upland area. The undulating leveled surface attains an average altitude of $800 \mathrm{~m}$. At the west, it nearly borders the Bohemian Forest hills and at the east it joins the Teplá Upland. The highest elevations in the Slavkovský les are Lesný (981 m) and Lysina (978 m) hills. Deeply incised valleys dissected parts of the area. In the ore district area, the detailed surface morphology is modified by large depressions caused by the collapse of old underground workings and by extensive dumps. The average altitude around the deposit is $620 \mathrm{~m}$. A single natural drainage in the area, the Slavkov brook, was modified in the Middle Ages to a channel for the transport of wood to the mines.

In the postwar period the Krásno mining area of 240.9 ha in total, has been claimed for exploitation of tin

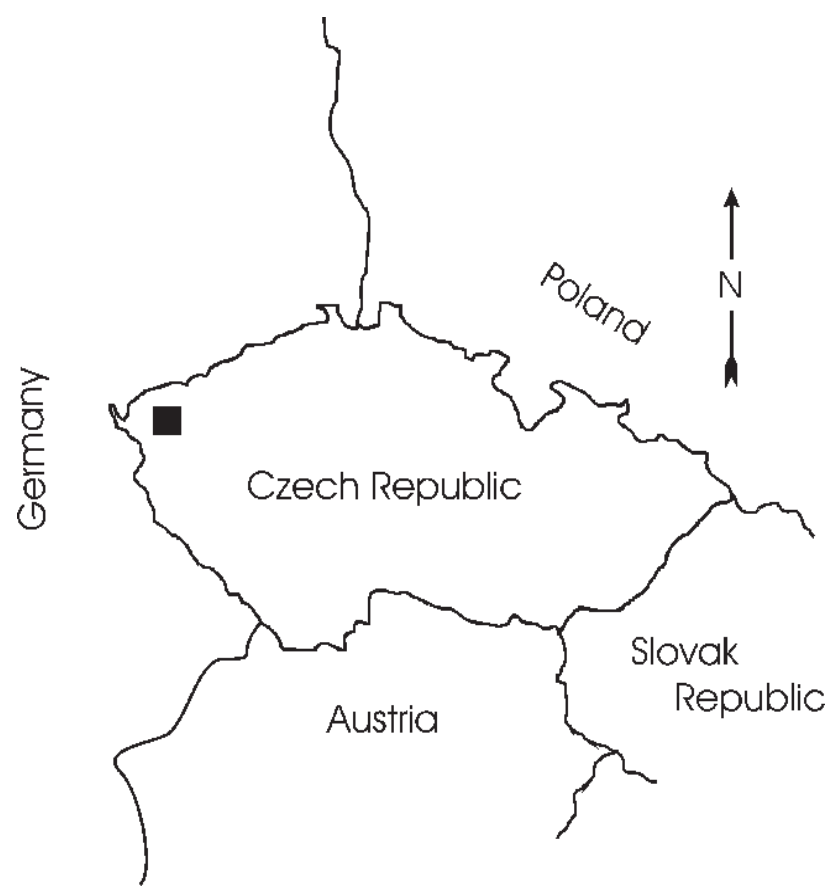

Fig. 1 Sketch map displaying the geographical localization of the Krásno ore district (black square). 


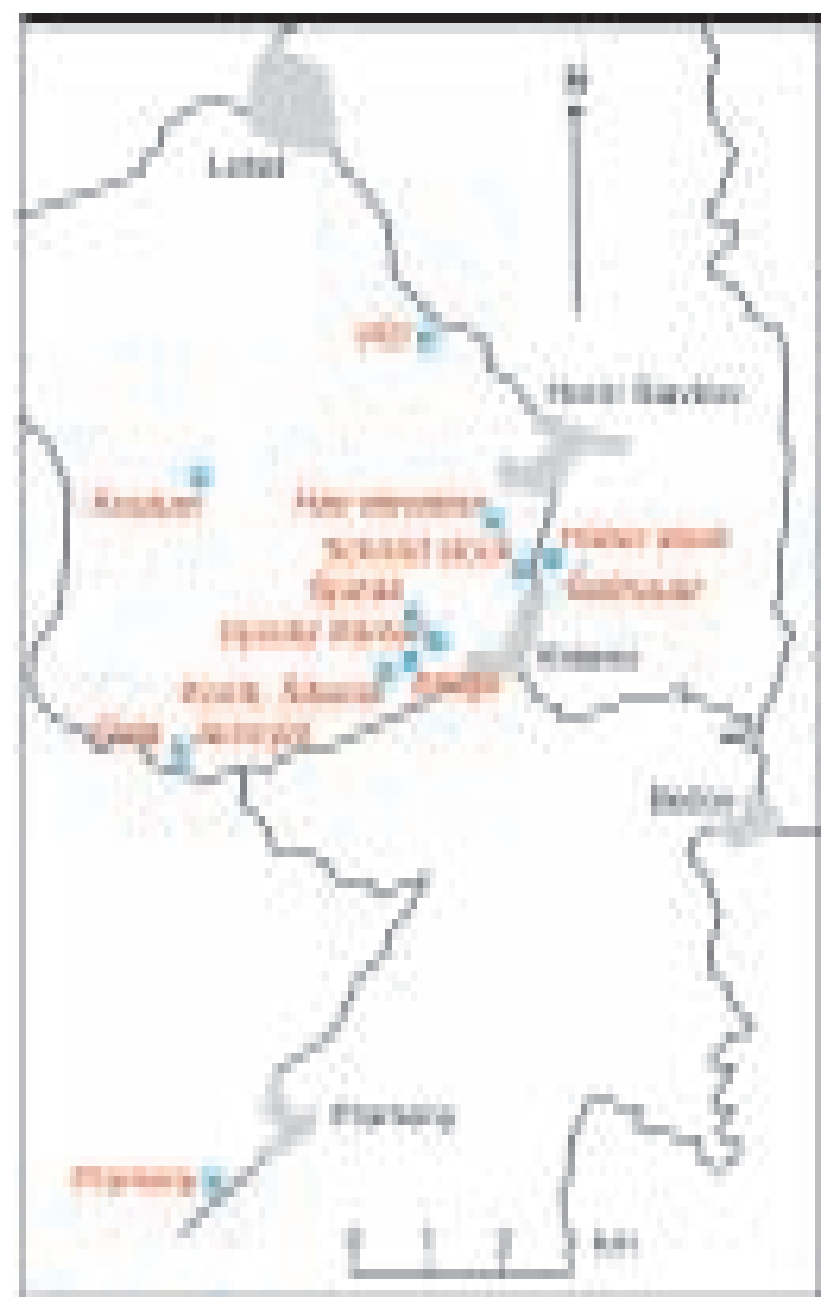

Fig. 2 A map showing the Sn-W deposits and occurrences in the Krásno - Horní Slavkov area

and tungsten ores, by ruling of February 11, 1961, with cassiterite, wolframite and chalcopyrite as ore minerals. The mining of tin and tungsten ores was terminated in January 1991. The Rudné doly Př́ibram n.p. enterprise (incorporated later on into DIAMO s.p.) was appointed to administer the Krásno deposit. The mining of uranium ores was active throughout 1948 to 1962 in proximity of the Krásno Sn-W deposit. The exploitation of uranium ores terminated in 1963. In 1992, a mining area of feldspar, of 16.9 ha in extent, was defined being administered by the KMK Granit s.r.o. Company. Since 1991 the area "Horní Slavkov - Krásno - Čistá" was claimed as a protected ore deposit area with $\mathrm{Sn}-\mathrm{W}$ ores and feldspar raw material, 3155 ha in extent and it is administered by DIAMO s.p. (sine 1995).

\section{History of mining in the Slavkovský les area}

The mining history of tin deposits in the Slavkovský les area can be described in three main periods: before $17^{\text {th }}$ century, $18^{\text {th }}$ to $20^{\text {th }}$ century, and the period after 1945 .

\section{History of ore mining before the $17^{\text {th }}$ century}

The first reliable written record of tin export from the Krásno area to western Europe and eastern markets is by an Arab merchant Ibrahim ibn Jakub, dated 965-966. Prior to underground tin mining in the area of Slavkovský les, cassiterite was exploited from alluvial deposits as early as the middle part of the second millenium before Christ (Majer - Jangl 1995). Since the $13^{\text {th }}$ century, tin production existed due to the exploitation of primary deposits. The mining was centred at Krásno and Horní Slavkov, the towns obtained mining town status in 1355 -1356. A major extension of tin mining occurred early in the $16^{\text {th }}$ century, particularly as the Huber stock was discovered in 1516. At that time, silver ore was mined in several ore veins near Horní Slavkov, which resulted in establishing a coin-minting office in Horní Slavkov during 1526-1527. In support of mining activities, the mine owner Jan Pluh of Rabštejn issued mining rules for silver mines in 1507 and for tin mines in 1509. During 1517-1541 the regulations were supplemented by several additional rules. In 1548 these regulations were declared as King's regulation obligatory for all mines in the Slavkovský les area.

The regulations specified methods of granting concessions, supervision of mining methods, specification of dimensions of underground workings and duties of mining administration. In addition to the Horní Slavkov Krásno deposits, tin mining proceeded at some other nearby locations including Čistá and Prameny. The mining kept intensifying during the $40 \mathrm{~s}$ and $50 \mathrm{~s}$ of the $16^{\text {th }}$ century, with an average annual production of 400-500 tons of tin. The mining was concentrated at the Huber stock in some vein zones, and main tin-bearing veins. Since 1548 the exploitation of the Schnöd stock started. The regular mining was supported by steady demand for tin, especially in Germany, as testified that major tin traders from southern Germany used to pay supplies in advance. Owing to quality and favourable pricing, tin from the Horní Slavkov district dominated in the markets of western Europe and in the first half of the $16^{\text {th }}$ century its export nearly replaced tin produced in Devon and Cornwall of England.

The permanent increase of tin mining in the Horní Slavkov district was adversely affected by war conflicts in 1546-1547 and introduction by King of tin monopoly during the years 1550-1555. These developments disrupted established export ties and resulted in the decline of mines. To boost the mine production, Krásno and Horní Slavkov were granted in 1547 the status of free mining towns. The same status was granted to Čistá in 1551. The discovery of the Schnöd stock in 1548 resulted in increased ore production. However, several events during the 60 s of the $16^{\text {th }}$ century caused mining decline such as civil war in France in 1562 and liberation war in the Netherlands against Spanish occupation in 1567. In the same year, an extensive fire demaged 200 houses in- 
cluding some public buildings in Horní Slavkov. In 1568 a major collapse of underground workings in the Huber stock occurred, followed shortly by a similar disaster in the Schnöd stock (Beran et al. 2001). Increase of living costs and expenses of mining characterized the following decades. Several mining ventures, both at the Huber and Schnöd stocks, had to apply for the financial support at the King's Czech Chamber - the highest economic institution in the country. The support was urgently needed for continued work on the major drainage adits.

During the following period from 1603 to 1620 decline in mining continued. Only 55 miners and 9 supervising personell were employed. The mining at Čistá was stopped in 1630 for a long time. Only during 60s of $17^{\text {th }}$ century, the state (King's) administration supported renewal of mining in the district. The support was directed at sinking a water-drainage shaft. Realization of this project permitted to exploitate deeper mineralized parts of the Huber stock. Late in the $17^{\text {th }}$ century, mining was also renewed at Čistá and some other locations in the Slavkovský les area (sine 1995).

All major veins and disseminated tin deposits were discovered during the period from $12^{\text {th }}$ to the middle of $16^{\text {th }}$ century. Early exploitation focused on cassiterite ores containing 8.5-10 wt. \% Sn. Later on, metal content dropped to an average of $1.5-2 \% \mathrm{Sn}$ and around 1700 tin content of the ore decreased to $0.2-0.5 \%$. Silver-bearing veins in proximity of Horní Slavkov were discovered and exploited early in $16^{\text {th }}$ century. Tin deposits were mined by shafts and inclines with galleries. Early workings especially at the Huber and Schnöd stocks were rather chaotic, without properly designed plan. Since about 1550 a tendency prevailed to a unified concept of mining. Four or five shafts served for ore exploitation while one shaft was used for ventilation. Two water-drainage shafts have been sunken beyond the periphery of the deposit. This system was in operation for a long time, but another drainage shaft was sunken in 1669 (Majer - Jangl 1995).

Adits provided access to some parts of deposits depending mainly on the terrain morphology. Such adits were made during the late $14^{\text {th }}$ century at Horní Slavkov and Krásno and also later at other places like Vysoký Kámen, Klinge, and Vlčí hills, Huber, Kladská (11 km southwest of Krásno), Čistá, and Prameny. Some prominent workings around Krásno include Stará štola, Jiřská, Těžařská, Pluhova, and Schnöd adits. The Pluhova adit (Fig. 3) was important for the whole ore district, as it was connected to numerous older workings and was used till uranium mining period in the $20^{\text {th }}$ century (Fig. 4). In a total length of $5.92 \mathrm{~km}$, it is functional even at the present time (Majer - Jangl 1995).

Mining methods used at tin deposits were comparable to those used at other vein-type ore deposits. However, a different system of narrow adits and chambers (Fig. 5) was used in exploitation of dispersed tin mineralization. The chambers were usually 10-15 $\mathrm{m}$ high and wide. Some chambers at the Huber stock and at Čistá were $30-40 \mathrm{~m}$ long, $10-20 \mathrm{~m}$ wide and $15-20 \mathrm{~m}$ in height. Miners used fire at tunnel faces and chambers to disintegrate rocks. Hammers, wedges and crowbars were used to cut the rock. A single miner produced 25-30 metric cents of rock per week, or 40-45 cents under favourable conditions. In narrow adits of a profile of

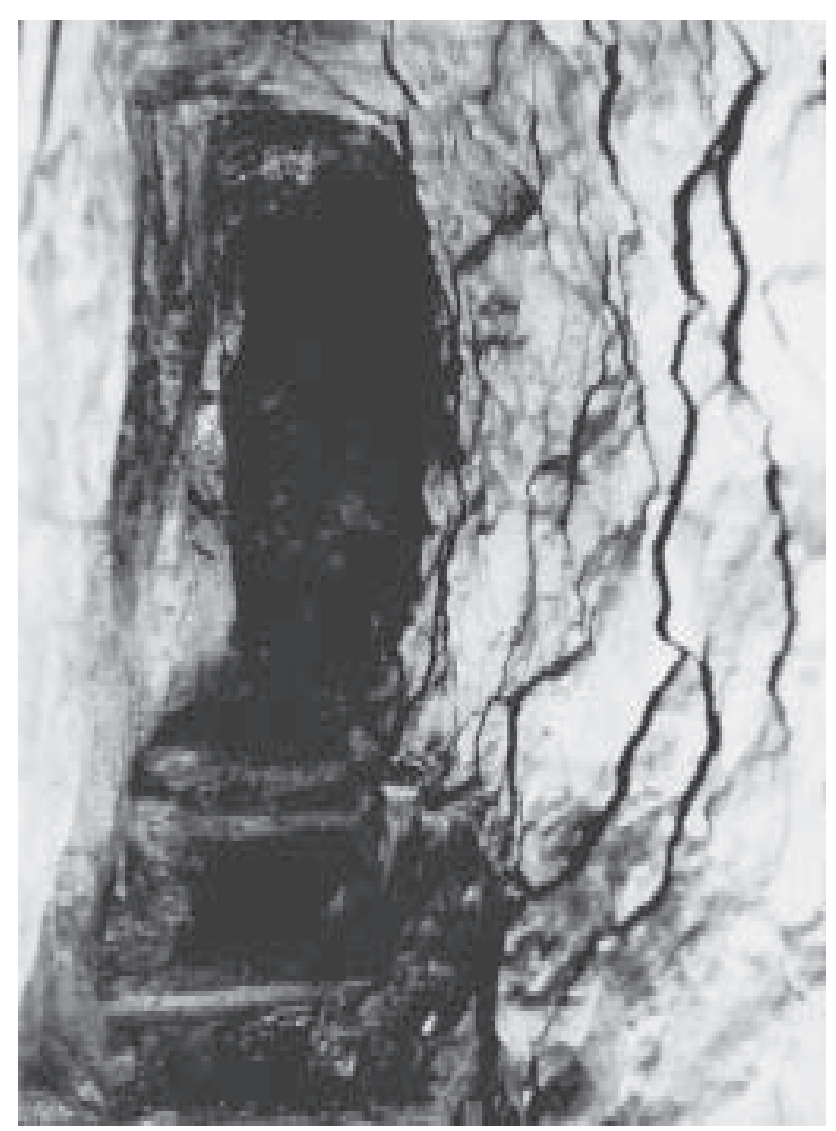

Fig. 3 The Pluhova adit in the area of Schnöd stock, VII ${ }^{\text {th }}$ level of Vilém mine (photo P. Beran, 1984).

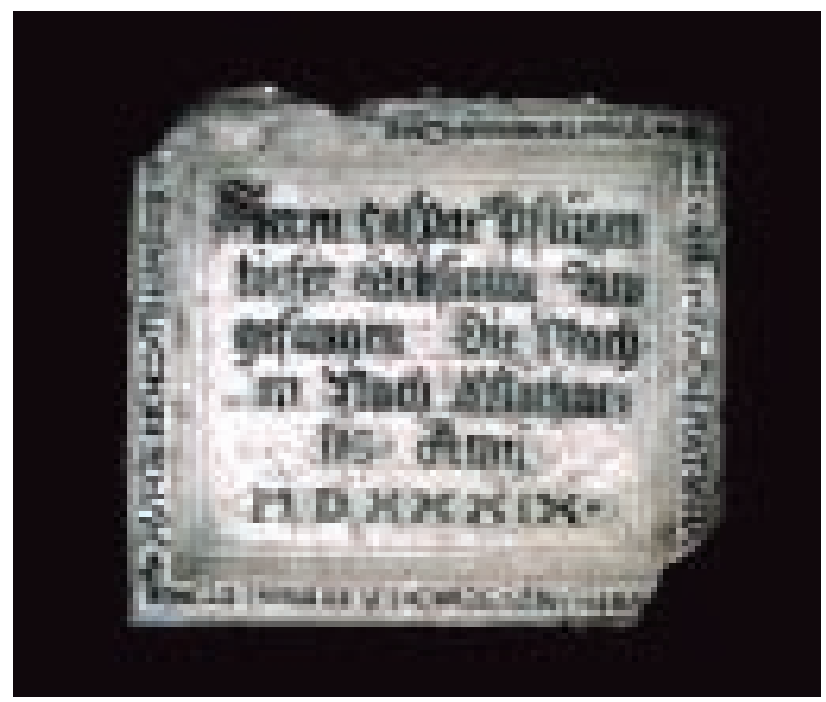

Fig. 4 Memorial plate at the entrance of the Pluhova adit, about 1539 (photo P. Uhlík). 


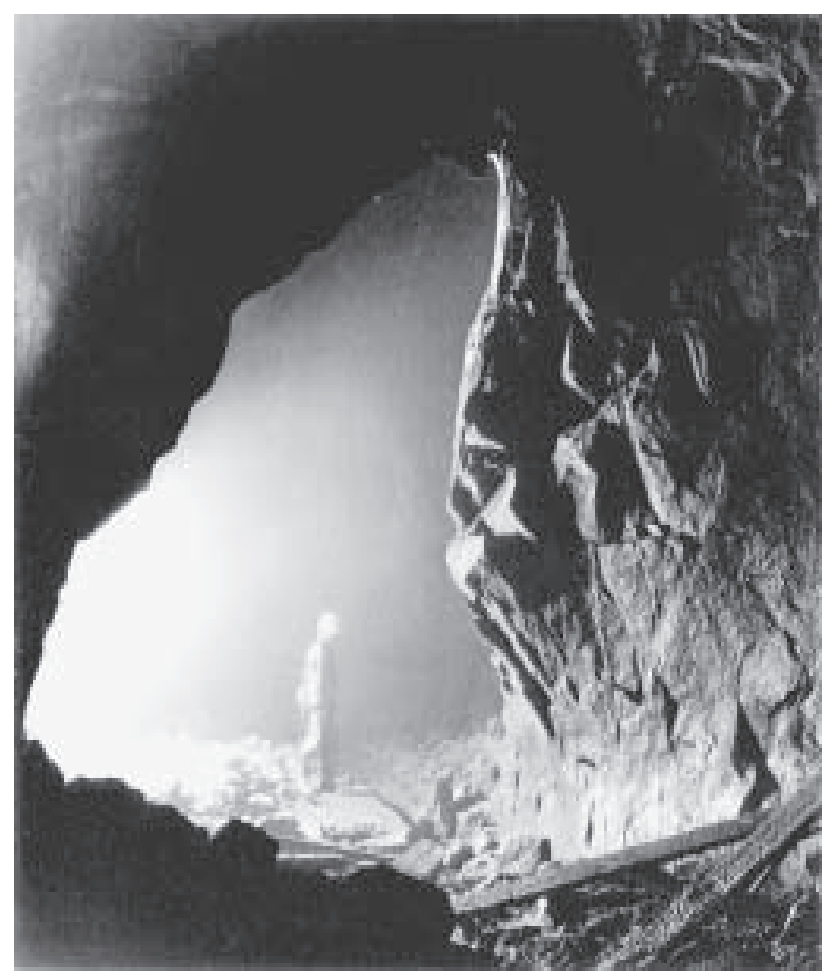

Fig. 5 Large chamber from $16^{\text {th }}$ century above level $500 \mathrm{~m}$ a.s.1. (photo K. Mlynařík 1975).

$170 \times 50 \mathrm{~cm}$, a single miner progressed by $30 \mathrm{~cm}$ per week (Majer - Jangl 1995).

Mine corridors used to be ventilated by spontaneous drought as some shafts served for ventilation. Adits were ventilated using chimneys and galleries interconnecting adits at various levels. The Kophan shaft and the Pluh adit served for ventilation from 1602 till the end of the $17^{\text {th }}$ century. A series of water-drainage adits and two or three shafts serving for water pumping, located outside the Huber stock, were used for draining the mines. The pumps were powered by water. The Huber stock was drained to a level of $200 \mathrm{~m}$ and the Schnöd stock, Čistá and Prameny deposits to a depth of $100 \mathrm{~m}$. At mine workings, where gravitational drainage via adits was impossible, pumping by horse-gear or pumps powered by water were used. Water wheels 3 to $14.5 \mathrm{~m}$ in diameter served to power pumps with efficiency of up to $1000 \mathrm{~m}^{3}$ per week (sine 1995).

Sufficient and regular water supply was important for mine operations. By the end of the $14^{\text {th }}$ century, a channel from Rota River was constructed and a new channel called Dlouhá stoka was put in operation in 15311536. Later on, the channel was connected to five large ponds and 13 smaller reservoirs with a total capacity of $630000 \mathrm{~m}^{3}$ (Majer 1970).

There was a high demand for wood used for mine timbering, constructions in pumping shafts etc. Large forest areas around Bečov were selected for free wood supply for mines. Uncontrolled wood usage resulted in removal of forests for a long distance from Horní Slavkov. The wood supplies during early stage of extensive tin mining are estimated to equivalent of 300 hectars of forest per year. By the end of the $16^{\text {th }}$ century, wood was transported to Horní Slavkov from distances of $30 \mathrm{~km}$. Large quantities of wood were used in tin smelting.

In order to obtain high-grade concentrate, ore used to be crushed manually by hammers and ground on manual mills. Since the $15^{\text {th }}$ century, crushers powered by water were introduced. Crushing in water was practicised to minimize the metal loss in fine powder fraction. When needed, ore was roasted and washed using sluices. Later in the $16^{\text {th }}$ century, 96 ore processing sites operated around Krásno and Horní Slavkov. Annual production of a stamper in the $16^{\text {th }}$ and $17^{\text {th }}$ century is estimated at 650 1000 tons of ore (Majer - Jang1 1995).

The intensity of mining in the Slavkovský les area during the $14^{\text {th }}$ to $17^{\text {th }}$ centuries was influenced by a variety of operational, economic, and political factors. Nevertheless, mining areas mainly around Krásno and Horní Slavkov (Fig. 6) produced about 60000 tons of metal for respective period. The accuracy of the estimate is affected by the absence of reliable data for the period from 1300 to 1500 . About $77 \%$ of the total quantity was produced in the Krásno district. The tin price depended on the foreign competition and demand, and on various political factors. The prolonged mining activities in the Slavkovský les area contributed to legislature and innovations in technologies.

\section{Mining history in $18^{\text {th }}-20^{\text {th }}$ century}

This period represents an important era in tin mining in the Slavkovský les area (Figs 7-10). Private investors operated mines in the Krásno district. During early stages of this period, tin production was sufficient to cover operation costs. In middle of $18^{\text {th }}$ century, the extent of underground workings surpassed the proportion of economic feasibility. Although the Huber and Schnöd stocks and dispersed mineralization contained sufficient ore reserves, mining became uneconomic. Unlike some major silver mining districts in Bohemia (Kutná Hora, Jáchymov, Pŕíbram), important for the state as the sources for silver coin minting, tin mining did not enjoy permanent state support. Interests in tin and later in tungsten production proved to be episodic and depended mainly on armament production.

Five-times during this period, state intervened by significant investments to increase production: in $70 \mathrm{~s}$ of the $18^{\text {th }}$ century, in early and middle parts of the $19^{\text {th }}$ century and during the World Wars One and Two. During these periods, the previous investments and technical innovations financed by state proved insufficient to continue economic production. Private operators continued mining but activity was often limited to cheeper picking of ore leftovers at upper levels, exploitation of small veins and even ore collecting at old dumps. State often continued in financing the most urgent operations such as 
Fig. 6 Historical map of mines between Krásno and Horní Slavkov, 1699 (District Archive Jindřichovice, photo L. Vondrášek).

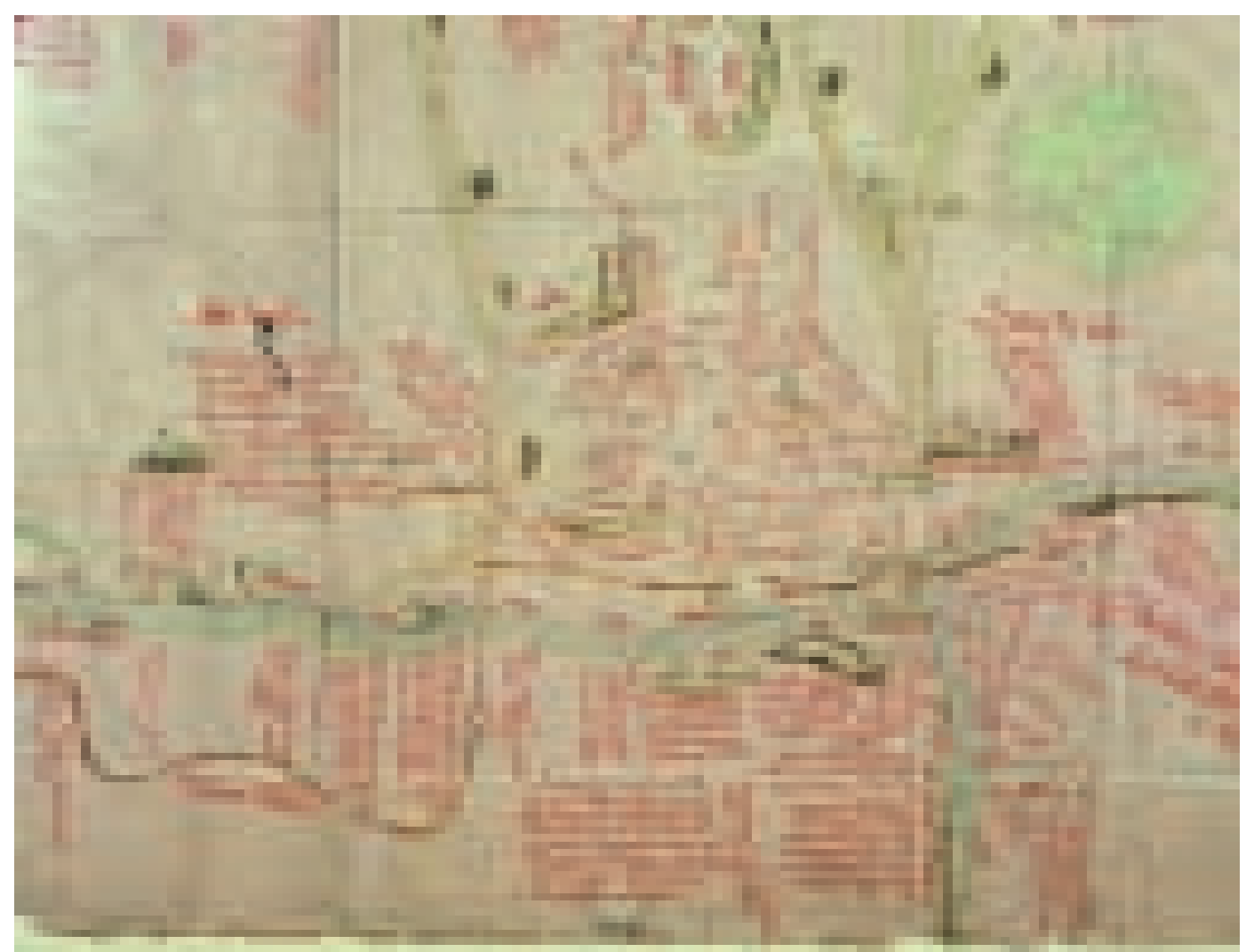

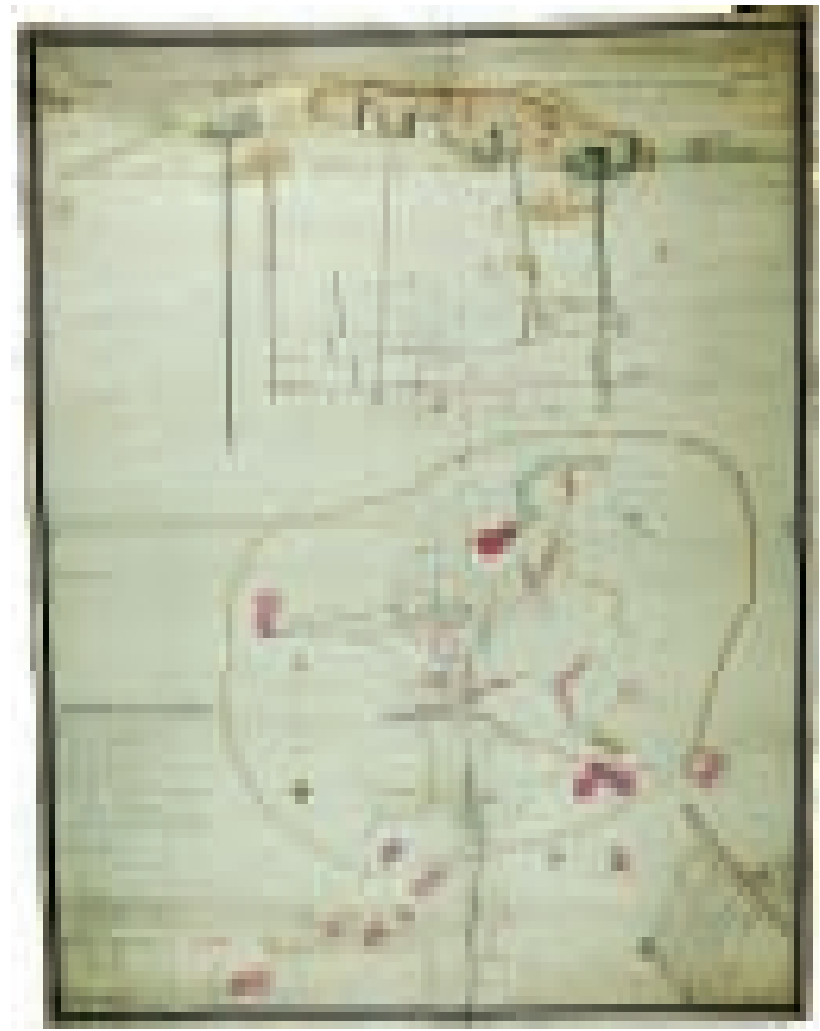

Fig. 7 Mine map of the Krásno ore district, 1756 (Central State Archive, Praha, photo L. Vondrášek)

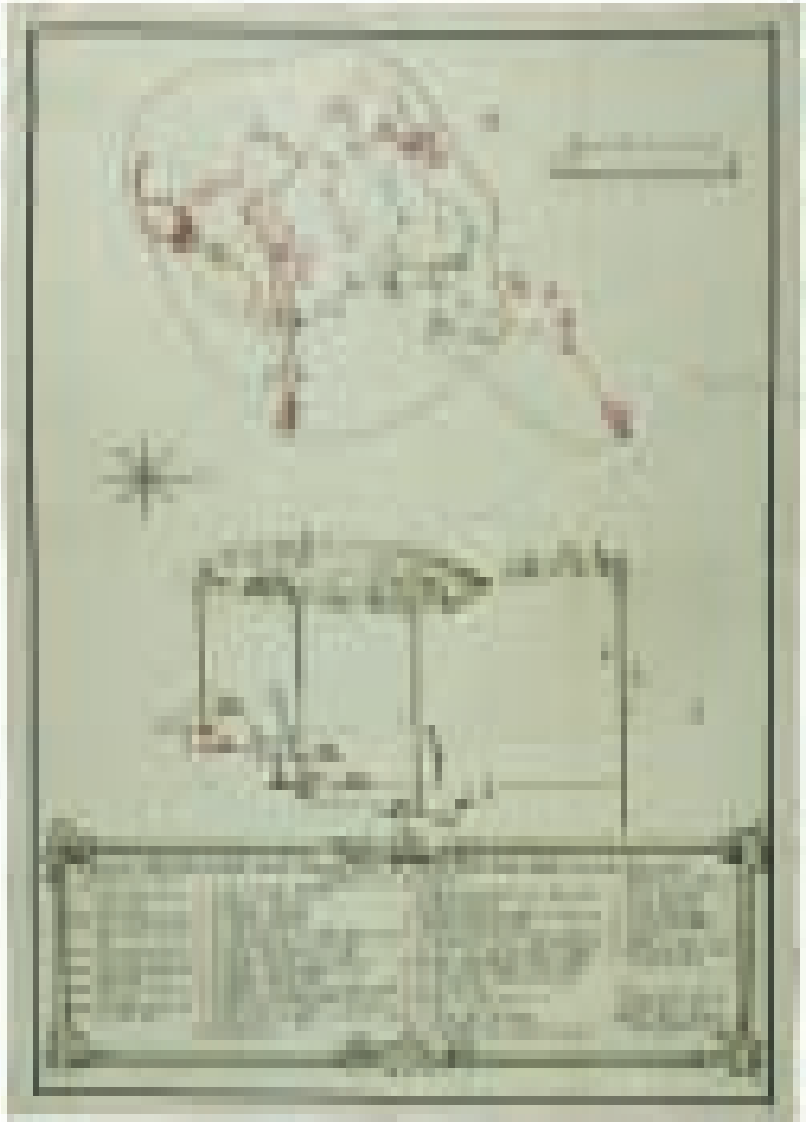

Fig. 8 Mine map of the Krásno ore district, 1768 (Central State Archive, Praha, photo L. Vondrášek). 


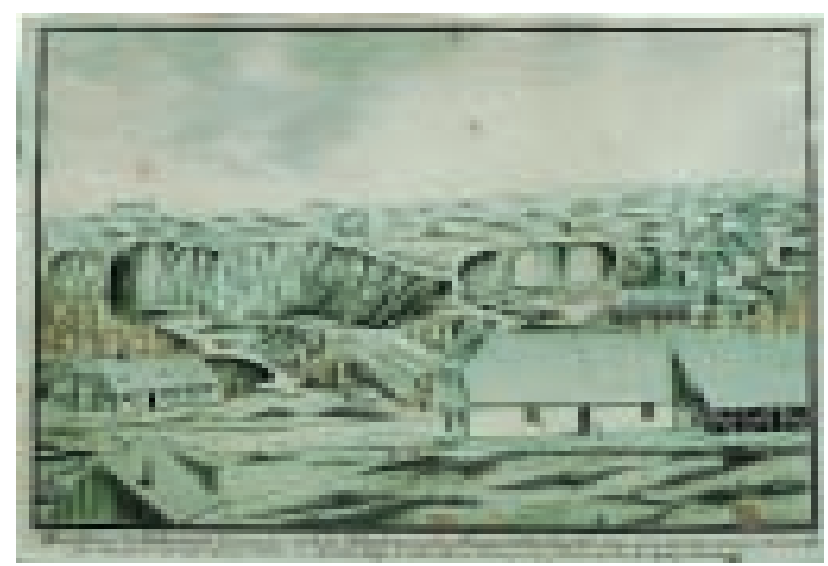

Fig. 9 Huber stock, Krásno, 1820 (District Archive Jindřichovice, photo L. Vondrášek).

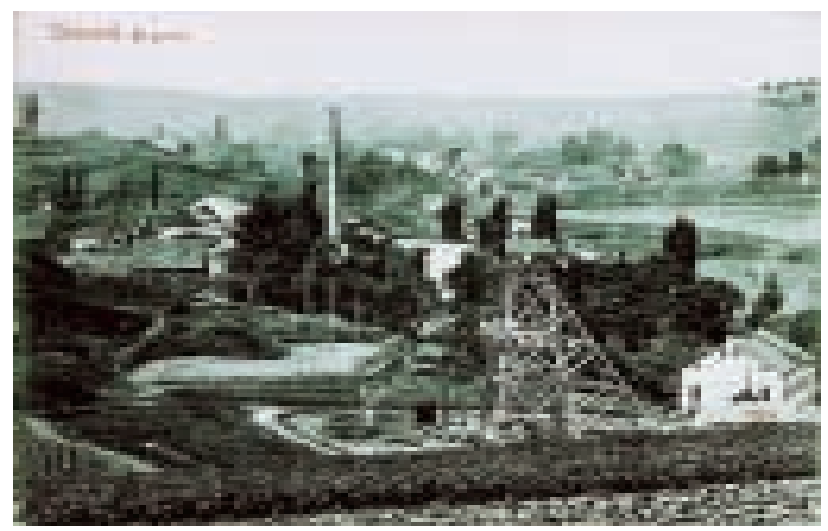

Fig. 10 Kreuz-zech mine, Krásno, 1906 (Archive of the Sokolov Regional Museum, photo P. Beran).

maintenance of major adits, water-pumping installations etc. (Beran et al. 2001).

A limited extent of manufacture and industrial enterprizing in the $18^{\text {th }}$ century was a factor in tin price and mining economy. Tin consumption in the production of tin kitchenware and white metal sheets was relatively low. Production from some other mines in the Bohemian part of the Krušné hory/Erzgebirge, e.g. Krupka, Hřebečná and Horní Blatná mines, and imports (or smuggling) of cheap tin from Saxony competed for the limited market. During the $19^{\text {th }}$ century industrial production increased but this development was accompanied by expansion of road and railway network for the transportation of goods. At the same time, these factors improved transport conditions for imports of cheap tin from South-eastern Asia and Bolivia. Local tin mining could not resist competion and mining ceased in middle $19^{\text {th }}$ century. The continued tin production at Krupka was based on processing of old tin products and benefication of raw tin from overseas. It became clear that tin mining in the Horní Slavkov district could continue only in absence of competion or under the condition that tin price would not be compared with the prices on the world market (Majer - Jangl 1995).

\section{Ore mining after 1945}

The mining history after 1945 is closely tied with the change of political situation in former Czechoslovakia. By paragraph $\S 12$ of the decree by the President of the Republic of October 24, 1945, No. 100 Sb., nationalization of mines and some industrial enterprises was declared, and following the agreement of the Minister of finance and Minister of industry according to $\S 1$ of the Government ruling of January 15, 1946, No. 6 Sb., the Příbramské rudné doly, national enterprise, was established. Also, by $\S 12$ and $\S 13$ of the President's decree No. $100 / 1945 \mathrm{Sb}$. and $\S 1$ to $\S 17$ of government ruling No. 6/1946, the Czechoslovak state as of January 1, 1946 tranfered property from the nationalized enterprises and state enterprises to the "Prríbram rudné doly, národní podnik" national enterprise (sine 1995). The properties of enumerated national enterprises included mines and processing plants for $\mathrm{Sn}-\mathrm{W}$ ore, including Krásno and Horní Slavkov. Thus, after 1945, exploitation in the Slavkovský les area, including the Krásno ore district, was conducted by the Příbram rudné doly enterprise, which was in 2001 incorporated into DIAMO s. p. enterprise.

Shortly after 1945, mining of Sn-W ores proceeded on a small scale at the Schnöd stock, opened by the Vilém shaft. An extensive prospecting program for uranium ores started as early as 1946. Uranium minerals occurred in the hydrothermal veins, which intersect metamorphic rocks around granite intrusions. In 1948, extensive uranium exploitation started at the Horní Slavkov ore district. During a short time, 26 shafts were sunken, $135 \mathrm{~km}$ of connecting galleries and $228 \mathrm{~km}$ of galleries following the ore veins were constructed in relatively small area. After extraction of 2668 tons of uranium, the mining in the Slavkov uranium district gradually ceased during 1961-1963. The uranium district did not extend into $\mathrm{Sn}-\mathrm{W}$ mines and thus after termination of uranium mining, galleries reaching into the $\mathrm{Sn}-\mathrm{W}$ mines were sealed.

A systematic opening of the Huber stock in 1957 marked the beginnings of mining of Sn-W ores on a larger scale. Opening workings started from the $4^{\text {th }}$ level of the shaft No. 9 of the former uranium mines. In the course of a tunnel excavation in November 1959, the flood by waters from the old mine working, estimated to a total of $100000 \mathrm{~m}^{3}$ occurred. This event resulted in draining of the water from the Huber stock. After removing damages resulting from the flood, mine opening workings, preparations, and exploration continued till 1965.

Calculation of ore reserves at the Huber stock was completed and presented in 1966 and at the same time the mining of ore started.

In 1968 the investment venture "Opening of the $\mathrm{Hu}$ ber stock" was proposed and approved in 1970 by the decision of the Goverment of Czechoslovakia and the Directors Board of Ore Mines and Magnesite Enterprises in Bratislava. In the frame of the first stage (1971-1973) 


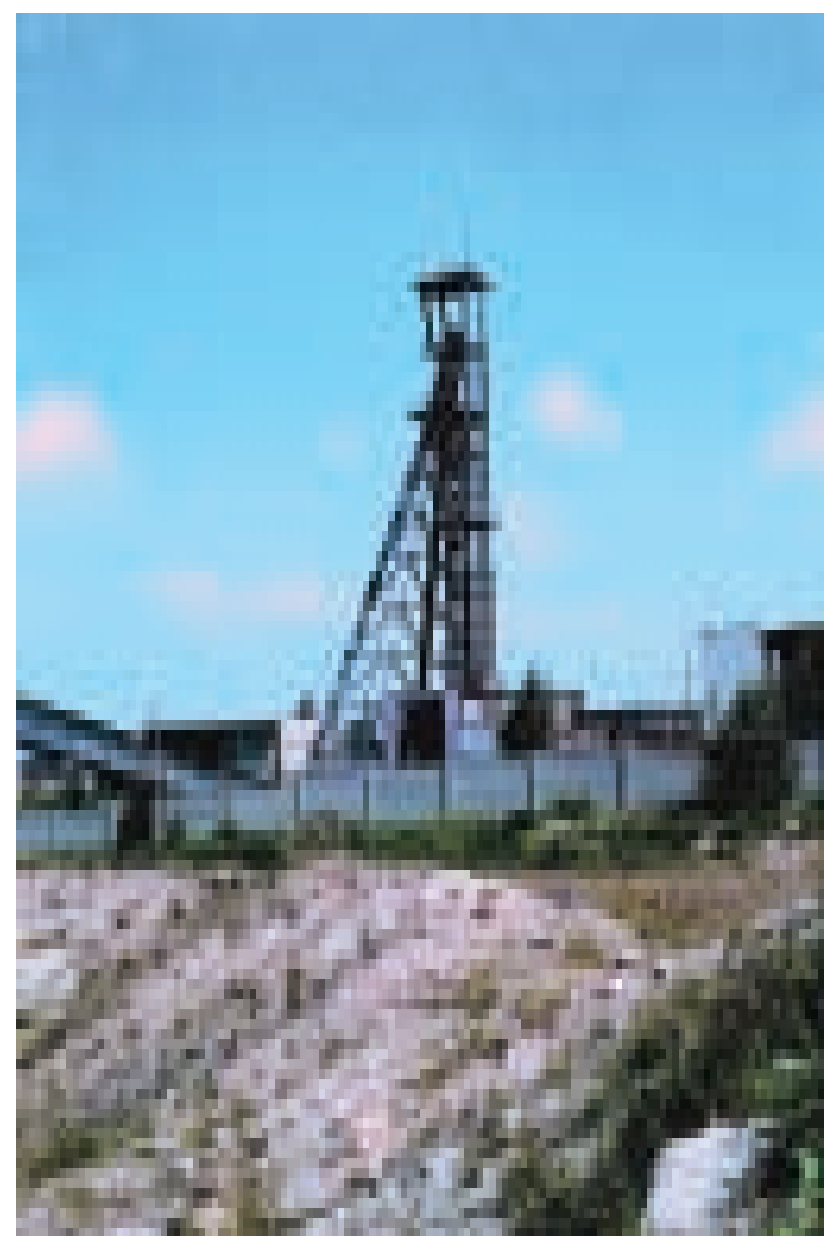

Fig. 11 The Huber shaft of Stannum mine (photo P. Beran, 1988).

new main Huber exploitation shaft (Fig. 11) was constructed, till 1982 (second and third stage) the original ore dressing plant with a capacity of 100000 tons was reconstructed and a new dressing plant with a capacity of 200000 tons was built (sine 1995). These investments, together with underground workings and preparation of ore blocks for exploitation, were planned to the mining and processing of 300000 tons of Sn-W ore per year.

The new Huber (Stannum) exploitation shaft at an altitude of $620 \mathrm{~m}$ a.s.1. opened the deposit by levels at $50 \mathrm{~m}$ intervals. The $4^{\text {th }}$ level $\left(475 \mathrm{~m}\right.$ a.s.1.), the $5^{\text {th }}$ level $(425$ $\mathrm{m}$ a.s.1.), and two additional levels at 500 and $455 \mathrm{~m}$ a.s.1. served as the main exploitation horizons. Besides the new levels Nos. 4 and 5 in the new Huber shaft, old levels (with intervals of $15 \mathrm{~m}$ ) were utilized from the Vilém shaft for the mining of the Schnöd stock. Owing to this situation, the $\mathrm{X}^{\text {th }}$ level of the Vilém shaft was approximately at $485 \mathrm{~m}$ a.s.1., i.e. above the $4^{\text {th }}$ level newly constructed from the Huber shaft.

At this time, unified names for the ore deposits in the district were proposed. The whole area is named Horní Slavkov - Krásno - Čistá ore district. It includes the main deposits as well as smaller showings of Sn-W ores. By administrative decision, the Huber stock and Schnöd stock deposits, together with adjacent area, were named
Krásno ore district. It includes Krásno and Horní Slavkov ore districts, except the Vysoký Kámen (greisen) and Vysoký Kámen (feldspar) deposits.

In the last period of mining in the Krásno ore district (1984-1989) large investments aimed to production of 300000 tons of crude ore per year were done. This included mainly new construction of ventilation shaft, large-diameter ventilation drillholes and introduction of mining machines without rails. Although by the end of $80 \mathrm{~s}$ of the $20^{\text {th }}$ century the mining of some large and rich deposit parts was possible, the planned goal of $300 \mathrm{kt}$ was never achieved and in 1989 and 1990 the amount of mined ore was $200 \mathrm{kt}$ per year. Better results were hampered mainly by irregular ore distribution and collapsed domains resulting from old mining but containing rich ore. Below the $4^{\text {th }}$ level of the mine, the ore blocks were mainly at the granite endocontact and were of smaller sizes.

The exploited ore after crushing and milling was gravity-separated and passed through flotation to remove $\mathrm{Cu}$ and $\mathrm{Zn}$ sulfides. The $\mathrm{Cu}-\mathrm{Zn}$ concentrate was treated in the base-metal plant at Krompachy (Slovakia). Sn-W concentrate was separated electromagnetically. Metalimex state enterprise exported the concentrates for metal extraction to Great Britain and later to Freiberg in Germany.

The mining in the Krásno ore district terminated for economic reasons in January 1991. For the production of one ton of tin metal, with the retail price of 157000 Czechoslovak crowns, a support of additional 357000 crowns was provided from the state budget (sine 1995). Within the project of the mine closure, a $\left(12 \mathrm{~m}^{2}\right)$ drainage adit, $1050 \mathrm{~m}$ long, was made (Fig. 12), collecting the water both from tin and uranium underground workings. The water is treated in the processing plant at Nadlesí to remove radioactive components and particularly iron, before release into the surface drainage system. According to the mine closure plan, surface constructions of the mines were in part removed and in part transfered to other organizations for alternative use. In the area of the Vilém mine (Figs 13-14), a Mining Museum shows history of mining in a wider area (Fig. 15), including the nearby Sokolov region. The mine was flooded and the surface marks of mining were removed. The Krásno ore district and nearby places host considerable quantities of tin, estimated at 60 thousand tons of tin metal in geologic reserves, including nearly 14 million tons of ore reserves.

\section{Geology of the ore district}

The Krásno ore district belongs to the Krušné hory Thuringia area of the Saxothuringian Zone of the Variscan orogenic belt. The Krušné hory (Erzgebirge) granite batholith, represented in the northern part of the Slavkovský les by the Karlovy Vary Massif, together with its envelope of metamorphic rocks, belongs to the above given unit. Granitoids of the Karlovy Vary massif are classified into an older igneous complex (OIC) mainly of biotite calc-alkali monzogranite and a younger igneous complex (YIC) ("Krušné hory granite") of alkali-feld- 


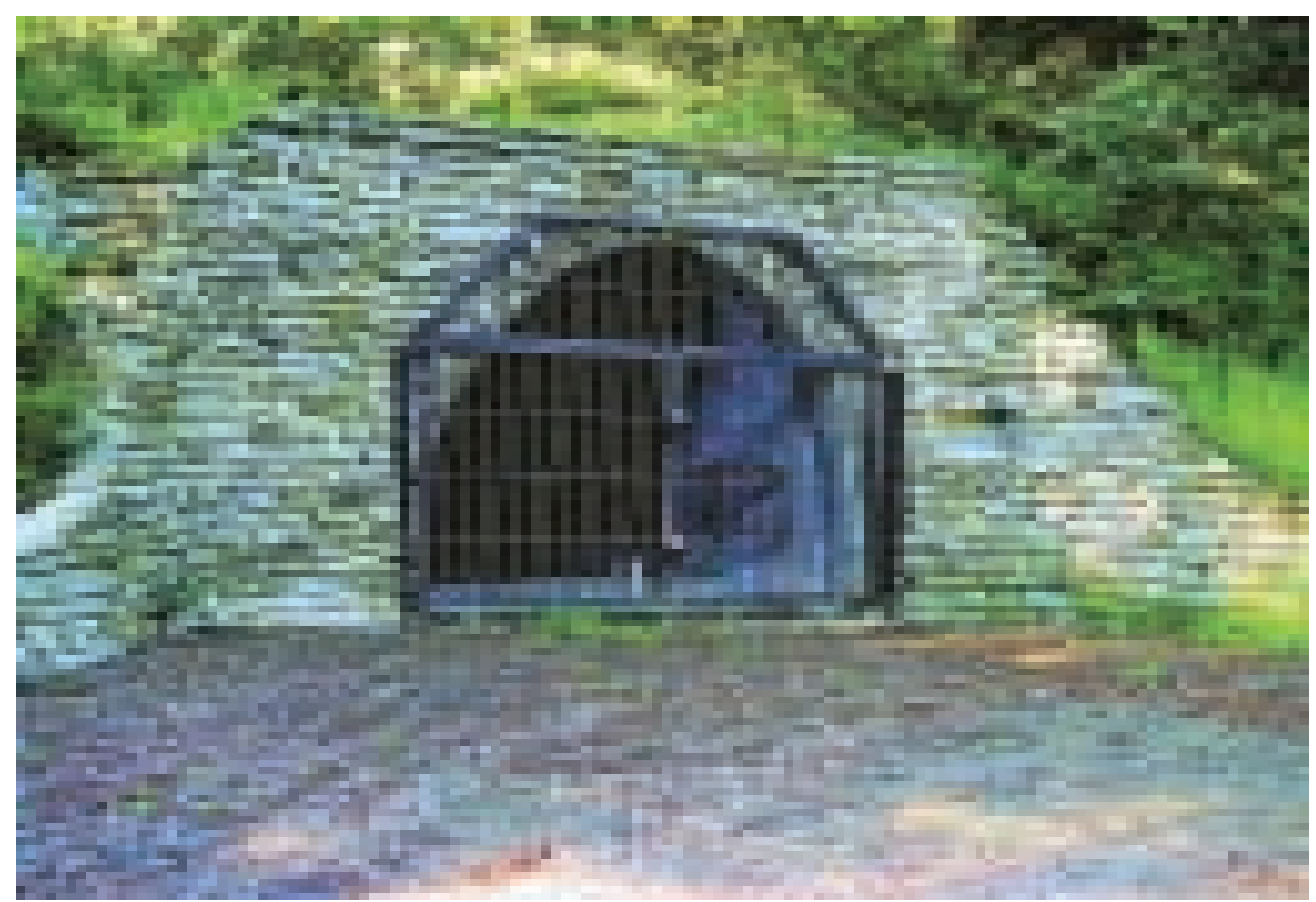

Fig. 12 Entrance of new drainage Barbora adit (photo P. Beran, 1997).

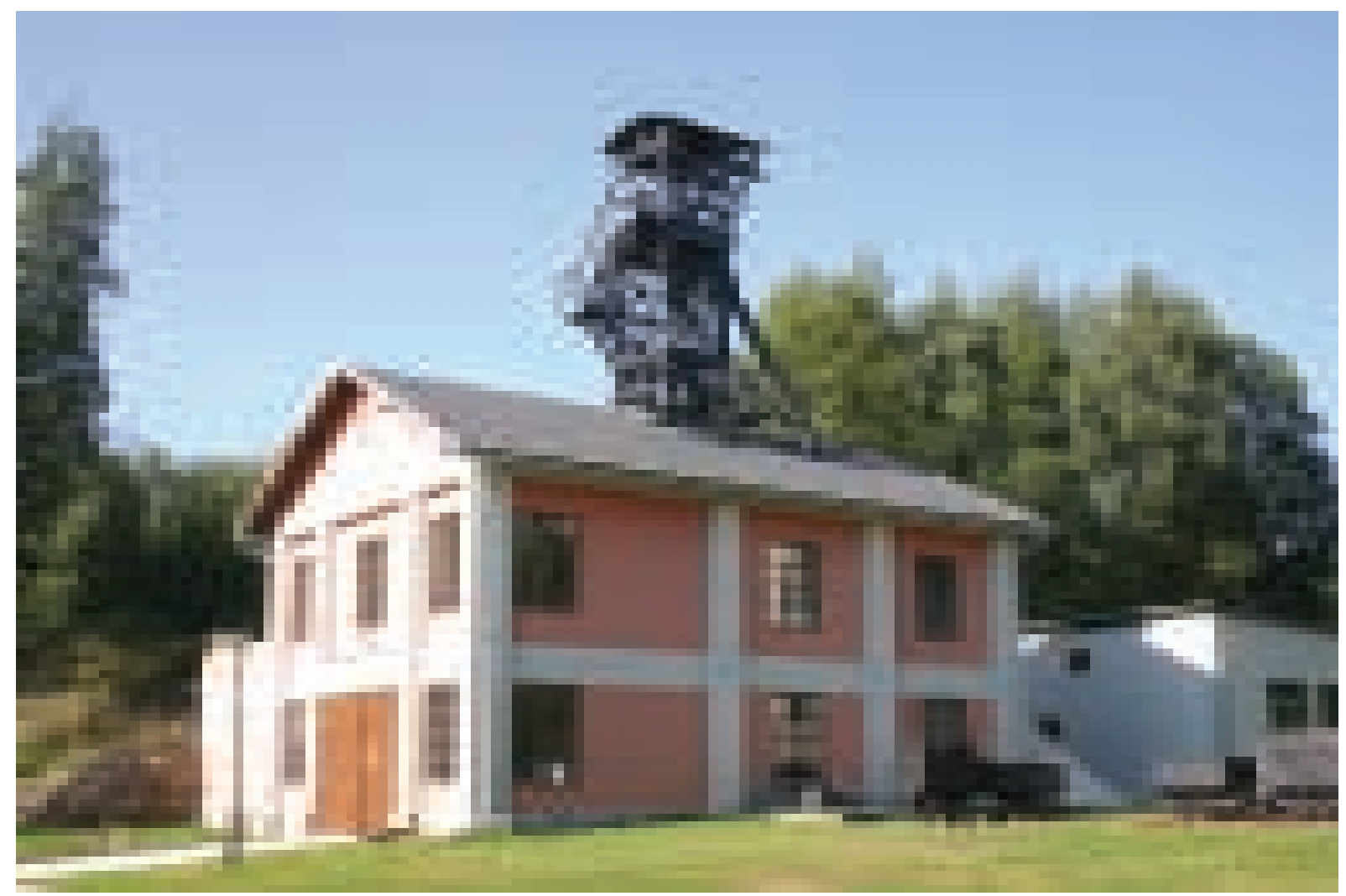

Fig. 13 The Vilém shaft in the area of Krásno mining museum (photo P. Beran, 1999). 
Fig. 14 The shaft bottom of the Vilém shaft, Krásno (photo J. Sejkora, 2005).

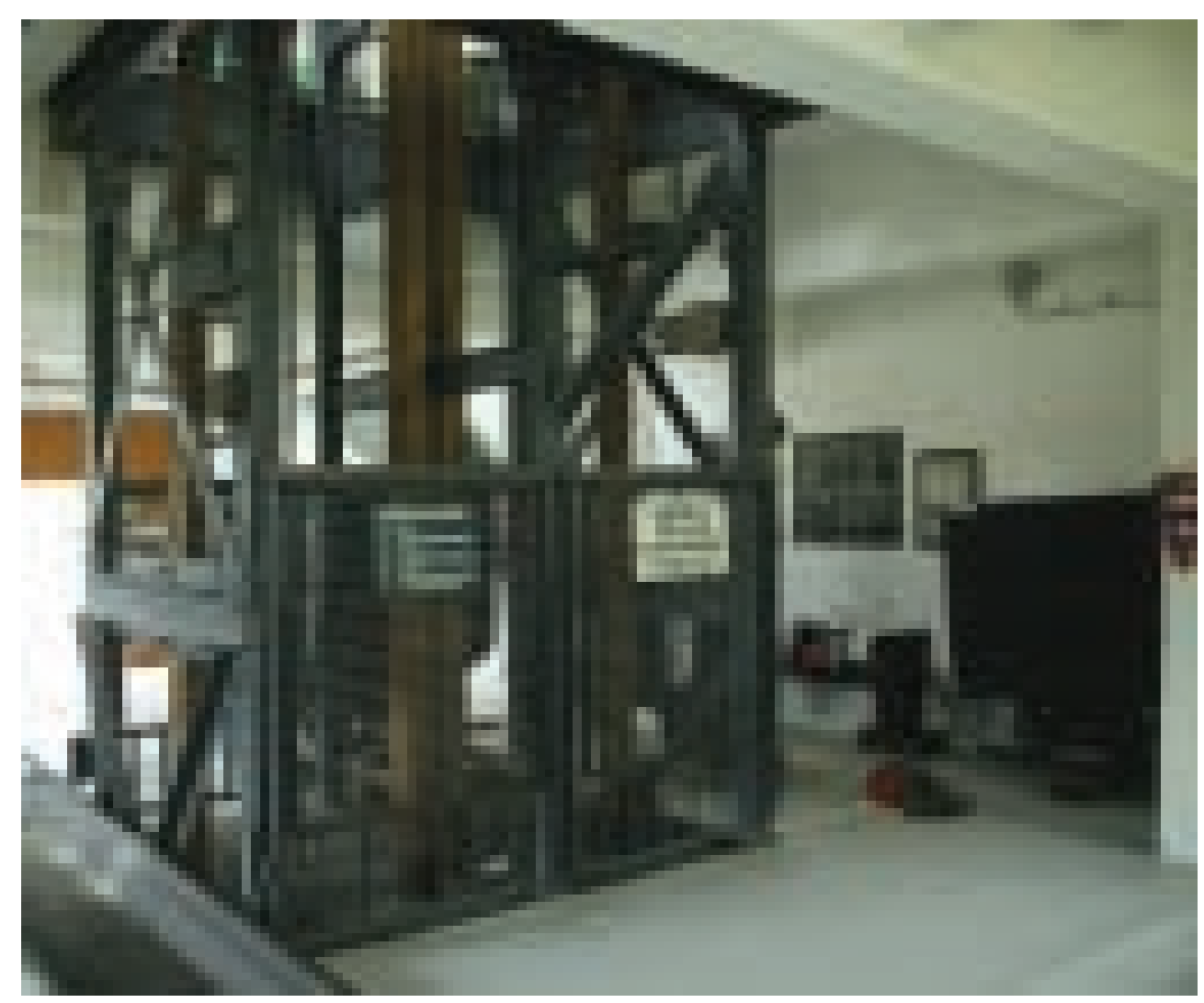

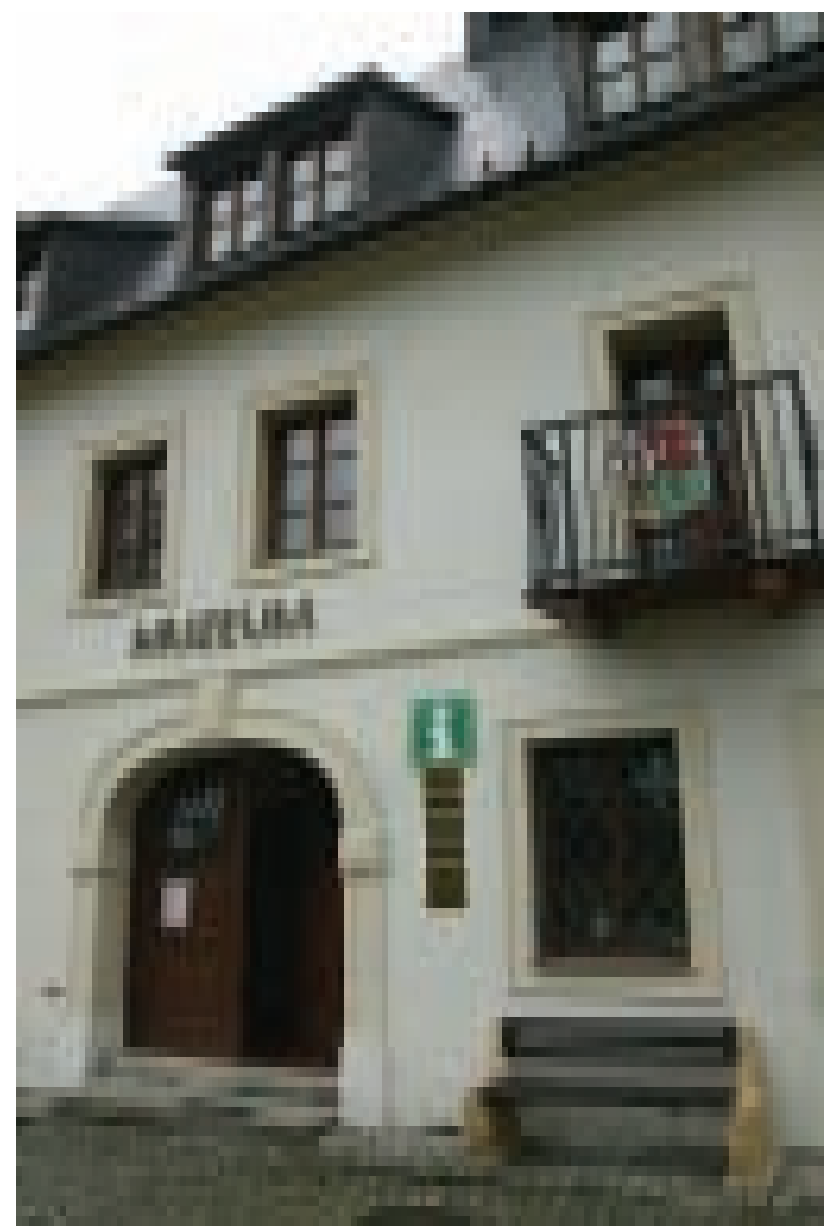

Fig. 15 Horní Slavkov museum (photo J. Sejkora, 2005). spar syenogranite, enriched in Li. In the Krásno ore district, highly evolved albite granite (Čistá - Krásno type, Fiala 1962) and Milíře type two-mica granite (YIC) predominate (Fig. 16).

A significant part of Sn-W mineralization is associated with small massifs of the YIC granites, which intruded along transversal NW-SE fault zones. Tin ore is concentrated in the apical parts of granite stocks or in elongated endocontacts of elevation zones. The Huber stock is the largest granite intrusion of this type. The envelope of the granite intrusions consists from intensively folded Proterozoic rocks, including biotite orthogneisses, paragneisses and migmatites.

\section{The main geological units}

The Slavkovský les area (called in the past as the Císařský les or Kaiserwald) represents an uplifted block bound by several fault-zones, including the Krušné hory fault at the NW, Mariánské lázně fault at the SW and the Litoměřice lineament zone at the SE. A fault zone in the Teplá river valley marks the limits at the East.

Together with the Krušné hory (Erzgebirge), the Slavkovský les area belongs to the southeastern part of the Saxothuringian Zone. This relationship is underlined by the presence of granites of the Krušné hory batholith and the associated $\mathrm{Sn}-\mathrm{W}-\mathrm{Li}, \mathrm{U}$, and $\mathrm{Ag}-\mathrm{Bi}-\mathrm{Co}-$ $\mathrm{Ni}-$ As mineralizations and by the similarities in granite magmatism in both areas, as emphasized by Fiala (1962). 

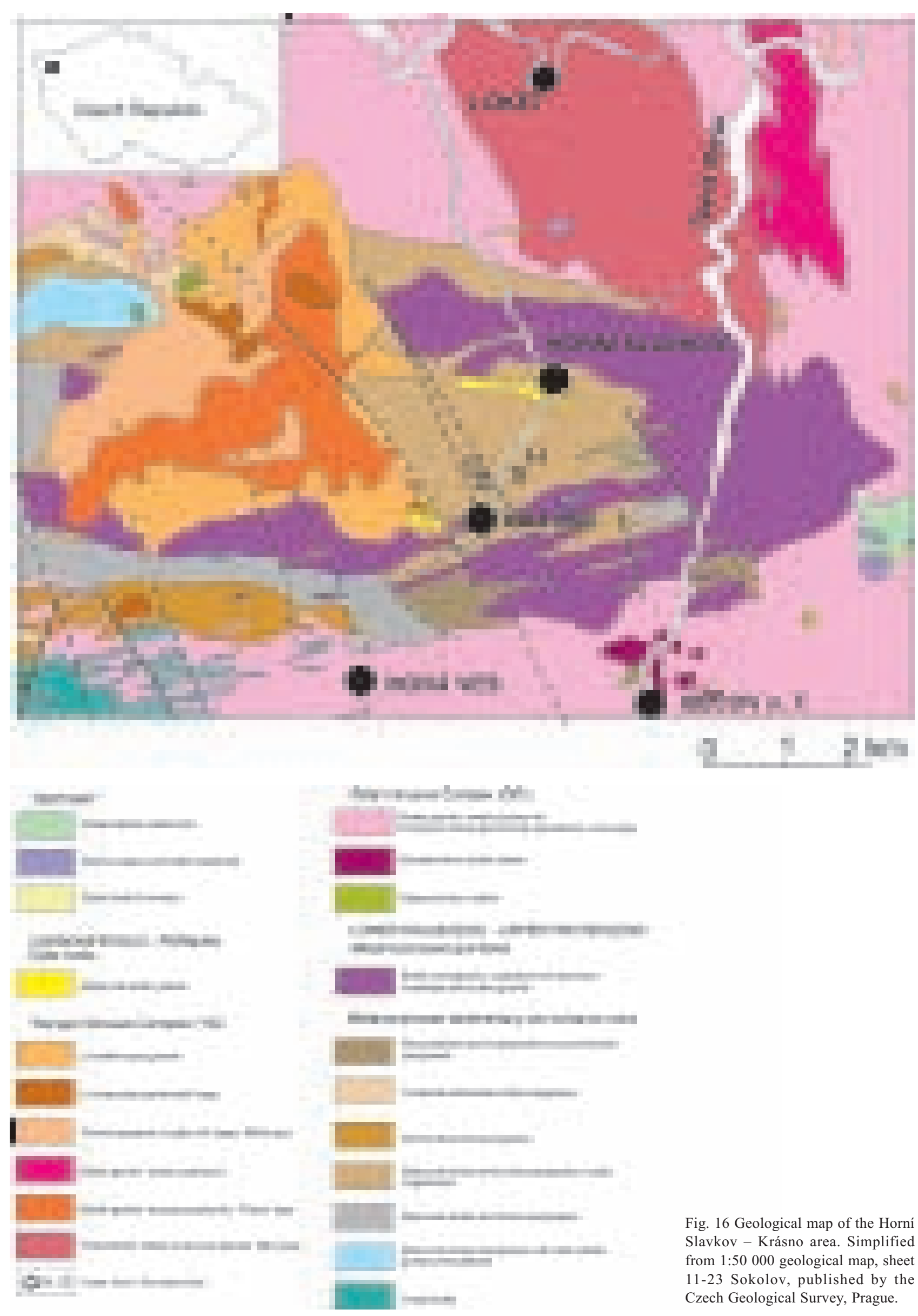

Fig. 16 Geological map of the Horní Slavkov - Krásno area. Simplified from 1:50 000 geological map, sheet 11-23 Sokolov, published by the Czech Geological Survey, Prague. 


\section{Metamorphic rocks of the Slavkovský les area}

The core part of the metamorphic complex in the Slavkovský les area of a probable Proterozoic age consists of biotite paragneisses and two-mica gneisses, in part accompanied by migmatites. It is crosscut by aplitic orthogneiss, migmatitic granite gneiss and biotite orthogneiss. Metamorphosed mafic rocks (amphibolites) are of limited occurrence. Vondrová (1962) studied the eastern part of the metamorphic complex in proximity of the Krásno ore district.

Metamorphic rocks of the eastern part are deformed into folds with steeply dipping axial planes and amplitudes on the order of hundred metres. Orthogneisses occur preferentially in the cores of antiforms. Three E-W trending belts of paragneisses with a variable degree of migmatization are separated by granite gneiss or biotite orthogneiss. The western part of the complex is relatively monotonous, including alternation of biotite paragneiss with orthogneiss. The crest of the structure contains small intercalations of pyroxene calc-silicate gneiss and amphibolite near Lobzy (Fiala 1962). The gneiss complex is cross cut by the dykes of aplite and aplitic granite abundant especially in the central part. The dyke swarms may contain somewhat older dykes related to the OIC Variscan granite pluton.

Metamorphic rocks in the NW part of the Slavkovský les area are probably younger than the rocks in the central part. A quartzite horizon at the base is overlain by a uniform sequence of mica-rich sillimanite paragneiss with layers of sillimanite-cordierite hornfels (Neužilová - Vajner 1963 and Fiala 1962). Numerous conformable bodies of Variscan biotite granite belong to the OIC type.

Metamorphic rocks south of the Rabůvka fault zone characterized by variation in lithology probably belong to the Upper Proterozoic. The unit, designated as Rabůvka Group (Pleinerová - Hladká 1960, Fiala 1962), includes biotite-cordierite-sillimanite, garnet, biotite-anthophyllite, biotite-amphibole, and amphibole hornfelsic gneisses and hornfelses. The rocks were affected by contact metamorphism and possibly by metasomatism by intrusion of OIC biotite granite.

At the south, the Rabůvka unit borders along a fault zone the Mariánské Lázně metabasite complex (MLMC) composed of amphibolites, gabbroamphibolites, eclogitic amphibolites, eclogites, and less widespread metasedimentary schists and gneisses. Geology, petrology and geochemistry of MLCM were studied by Fiala (1958), Kastl - Tonika (1984), Timmermann et al. (2004), Štědrá (1996), Štědrá et al. (2002), and Štědrá (2003). A serpertinite belt at the northwestern edge of MLMC marks the boundary against structurally lower Kladská Unit, classified with the Lower Palaeozoic of the Saxothuringian Zone (Kachlík 1997).

The Kladská Unit, considered to be the stratigraphically youngest member among the metamorphic rocks of the Slavkovský les, includes phyllitic schist ( \pm andalusite), quartzites, graphitic schists enriched in apatite, carbonate intercalations, and amphibolites. The sequence studied by Fiala (1962) hosts the uranium veins.

\section{Granitoids of the Slavkovský les}

A large part of the Slavkovský les area is underlain by Variscan granitoids, belonging to the southern part of the Krušné hory (Erzgebirge) batholith. Owing to the obvious association of younger granites with the Sn-W-Li mineralization, the rocks attracted attention and were repeatedly studied during the $20^{\text {th }}$ century. The older geological, petrographical and petrochemical data were presented by Fiala $(1962,1968)$, new data were published by Jarchovský - Štemprok (1979), Štemprok (1986), and Breiter et al. (1991).

Three main granite groups are recognized: a) OIC granitoids, including biotite granite, minor masses of gabbrodiorite and quartz diorite, b) transitional group of twomica granite, c) muscovite albite YIC granite with an enrichment in $\mathrm{Li}$ and $\mathrm{F}$.

Granitoids of the OIC group crop out at large continuous bodies north of Horní Slavkov (Loket - Vítkov), in the central area (around Nová Ves) and at the southwest of the area. Aplites, at places containing tourmaline, close the magmatic sequence. A prominent granite type is the Loket porphyritic granite with euhedral phenocrysts of alkali feldspar several cm long, exhibiting typical Carlsbad twinning. Plagioclase in the groundmass is oligoclase to sodic andesine. Some varieties contain minor amphibole.

Granites of the transitional group show geochemical features between those of OIC and YIC granites. They include two-mica granite and biotite granite with subordinate muscovite and accessory andalusite or tourmaline (Fiala 1968).

The YIC granites crop out at small massifs localized often at intersection of fault zones. These are represented by the Krudum massif at the northeast (among Krásno, Čistá, Rovná, and Nadlesí) and the Lesný-Lysina massif at the southwest (among Kladská and Kynžvart). Petrochemical variation has been noted mainly in the variable content of $\mathrm{Li}, \mathrm{Rb}$ and $\mathrm{F}$, while the bulk compositions remain uniform. Maximum enrichment in $\mathrm{Li}$ and F characterizes the so-called Li-F granites (Kovalenko et al. 1977). Characteristic petrographic features include enrichment in albite, replacement of feldspars by muscovite, replacement of biotite by Li-bearing micas, and the presence of accessory topaz.

The Krudum massif, $50 \mathrm{~km}^{2}$ in outcrop, shows a sequence of granite intrusions. Fine-grained porphyritic biotite granite with muscovite forms the central part and contains transitions to a coarse-grained facies (Svárov-Polom) or to the types similar to granite porphyry. These rock types do not show typical autometamorphism, contain low concentrations of volatile elements and are classified by some authors (Št’ovíčková in Polanský et al. 1973, Jarchovský - Štemprok 1979) with transitional granites.

The northwestern part of the Krudum massif consists of the Milíře type of two-mica granite, which is porphy- 
ritic at places and carries signs of autometamorphism. At some localities, e.g., the Sklenný vrch elevation, it shows weak greisenization, structurally lower positioned feldspar-enriched derivates and a marginal pegmatite at the contact with hanging wall biotite-sillimanite-cordierite hornfelsic gneiss (S-2 borehole, Jarchovský - Pavlů 1980). Novák (1988) recorded similar features including greisenization, sericitization, kaolinization and formation of accessory topaz and cassiterite in this granite.

Highly evolved Li-F granites afftected by autometasomatism belong to the YIC granites. Compared to the Milíre type, these granites contain increased amounts of albite, Li-mica, and topaz, in addition to perthitic orthoclase and quartz. Of the trace elements the granites are enriched mainly in $\mathrm{F}, \mathrm{Li}, \mathrm{Rb}, \mathrm{Cs}$ and depleted in $\mathrm{Ba}, \mathrm{Sr}$, $\mathrm{Ti}$, and $\mathrm{Zr}$. The main representative of $\mathrm{Li}-\mathrm{F}$ granites in the Slavkovský les is fine-grained to medium-grained Čistá granite (Fiala 1968). It occurs in northern, southern, and southeastern parts of the Krudum massif and continues below the Slavkov gneiss roof pendant towards the Vysoký Kámen locality. It represents the main rock type in the Krásno district, where it contains important greisen-type accumulations of $\mathrm{Sn}-\mathrm{W}$ ores. Fine-grained porphyritic granite occurs as a variety of this granite. It forms relatively small bodies with sharp contacts to the medium-grained granite. It is documented from deeper levels of the Huber and Schnöd stocks and in the Lánský dvůr elevation.

Albite-topaz microgranite cements fragments of biotite gneiss roof above the apical part of the Huber stock and represents thus intrusive breccia pre-dating metasomatism and greisenization (Jarchovský - Pavlů 1991). This microgranite is comparable with ongonites described from Mongolia (Kovalenko et al. 1971) or to extrusive rhyolites described from the USA (Christiansen 1983).

Aplitic leucocratic albite granite containing only negligible amount of mica, carrying topaz, apatite, and sometimes beryl (Polák et al. 1969) belongs probably to the youngest differentiates of YIC granites. Alkali metasomatism resulted in the formation of $\mathrm{Na}-\mathrm{K}$ feldspathites (Fiala 1968, Pácal - Pavlů 1972, 1979), giving rise to ceramic feldspar deposit at Vysoký Kámen near Krásno. A marginal pegmatite, the so-called stockscheider, frequently occurs at the top of Li-F granites. Where the contact is nearly horizontal (dip of $0-30^{\circ}$ ), the pegmatite is up to several metres thick, but it becomes much thinner (few centimetres to zero), where the contact is steep.

\section{Neovolcanics}

Tertiary volcanics occur at few places in the Slavkovský les area. Nefeline basanite forms the top of the Lysina hill southeast of Lázně Kynžvart (Fiala 1962) and olivine basalt occurs at the Buková hill NW of Bošířany (Vondrová 1962). The neovolcanics indicate that some pre-existing faults served as magma conduits during this event.

\section{Ore deposits in the Slavkovský les area}

Important Sn-W ore deposits occur in the Krudum granite massif - the Krásno ore district at the southeastern margin and the Čistá deposit at the southern contact. Mineralization in the southern part of the area is rare, except for a small granite stock west of Prameny.

There are two main morphological types of tin-tungsten mineralization. Greisen bodies in the apical parts and along flanks of Li-F granite stocks carry disseminated $\mathrm{Sn}-\mathrm{W}$ ores. This type represents the dominant part of the ore and was the main exploration target. Morphology of greisen bodies is rather complicated but tabular or hoofshaped bodies up to several tens of metres thick prevail. Greisens may occur at some distance (about up to $30 \mathrm{~m}$ ) from the granite contact but they are often tied directly to the contact with the country gneiss. The vertical range of the endocontact greisens does not exceed $200 \mathrm{~m}$ but the richest parts are limited to the distance of $50 \mathrm{~m}$ from the contact. The apical parts of stocks carry light coloured quartz-topaz greisen and intermediate or deeper zones contain a darker quartz-topaz-zinnwaldite greisen. Sulfides often accompany cassiterite and wolframite in the upper parts but they are absent at deeper levels.

Quartz veins with the wall rock greisenization represent the second type of Sn-W mineralization. They occur in the exocontact of mineralized granite cupolas. The best examples offer the Gellnauer and Hán veins and the Marie and Vlčí Dvůr veins. These veins were extensively exploited in the past but their importance declined with the introduction of mechanized mining. They also served as an indication of mineralized granite stock at depth. Dark greisens accompanying quartz veins in gneiss were designated as "zwitter". On transition to neighbouring granite, such quartz veins became thinner and the associated greisenization in surrounding granite was more extensive, indicating thus transition to endocontact greisens.

Hydrothermal veins with uranium and Ag-As-Bi-Co-Ni minerals represent another type of vein mineralizations. The veins were extensively exploited after the World War Second around Horní Slavkov (the Horní Slavkov uranium ore district). Insignificant are $\mathrm{Pb}-\mathrm{Zn}$ veins near Kynžvart (16 km southwest of Krásno), and Fe-Mn and fluorite-barite mineralization near Novina. Among industrial non-metallic raw materials, the Vysoký Kámen deposit of Na-K feldspar is the most important.

\section{General characteristics of deposits in the Krásno ore district}

In the area of the Stannum company activities around Krásno and Horní Slavkov, several deposits and some minor localities of tin-tungsten ores were prospected and considered for mining with the aim to utilize the dressing plant. There were some variations in mining methods, contents of economic minerals, and ore dressing requirements among individual deposits. As a rule, tin, tungsten, exceptionally copper and lithium, were the sub- 
ject of interest. In view of proximity of the dressing plant and the possibility to exploit some deposits by open pit mines, even some relatively low-grade primary ores were considered for mining.

Although the geology of deposits in the Slavkovský les area shows many common features, the actual geological situation at individual deposits is variable. Beran - Beranová (1995) classified the deposits in six groups:

- the Jeroným deposit at Čistá and showings in the neighbourhood,

- group of deposits and showings around Krásno (Vysoký Kámen, Koník, Vysoký Kámen-granite, Klinge, and Šibeník),

- the northern zone near Horní Slavkov (Smrčiny and Hán elevations, Špičák, veins in the Slavkov gneiss roof pendant),

- small showings of mineralization and low-grade Sn-W ores in northern and southern parts of the Slavkovský les area,

- the Krásno ore district (including deposits Huber and Schnöd stocks, area southwest of the Gellnauer and Lánský Dvůr elevations, area to the South and Southeast of the latter, the Gellnauer set of veins etc.),

- alluvial deposits along the Stoka stream.

\section{Geological situation of the Krásno ore district}

The Krásno deposit comprises several elevations (cupolas) of a large body of the autometamorphosed YIC granites and its dyke suite. The largest elevation is the $\mathrm{Hu}-$ ber stock with its apical part exposed at the surface. In the course of mining during the past centuries, the upper part of the cupola was mined out. Extensive refuse dumps later on covered the resulting funnel-shaped open pit. The Schnöd stock had its apical part covered by the $70 \mathrm{~m}$ thick Slavkov gneiss roof pendant. The extensive mining in the past also resulted in collapse reaching up to the surface. Both the stocks have a shape of a blunt cone with an elliptical base, widening with depth. At a level of c. $485 \mathrm{~m}$ a.s.l. the stocks join to a single body, with projected centres of the two stocks trending NW-SE and located $700 \mathrm{~m}$ apart. The width of the stocks at this lev- el is c. $400 \mathrm{~m}$. In the area northwest of the two stocks, there is a flat granite elevation, which joins the northwestern side of the stocks.

The granite of elevations has a discordant intrusive contact with the gneiss envelope. The contact plane is uneven, with local steps of several metres. The dip of the contact plane varies from $50^{\circ}$ to $70^{\circ}$ along the slopes of cupola but at the $4^{\text {th }}$ level $(475 \mathrm{~m}$ a.s.1.) it becomes flat with a dip of $20^{\circ}$. The contact is rimmed by a marginal pegmatite (stockscheider), which is from several $\mathrm{cm}$ to nearly $4 \mathrm{~m}$ thick. In the deeper parts with flat-lying contact, the marginal pegmatite is only several $\mathrm{cm}$ to several $\mathrm{dm}$ thick.

Several marginal tin-bearing localities explored by the Geoindustria Company (Najman 1990) belong spatially to the Krásno deposit. They include the Lánský Dvůr elevation, NW, SE and S surroundings of the Huber stock and the so-called K-5 elevation. In addition, the Gellnauer set of veins and veins in the area to the south, and SE of the Huber stock are also classified with the Krásno deposit.

\section{Tectonic situation in the Krásno ore district}

Predominant tectonic structures are fractures striking NW-SE and NE-SW. The N-S and W-E structures are of lesser importance. The fractures are mostly less than $0.5 \mathrm{~cm}$ wide but some fractures are $2-5 \mathrm{~cm}$ (exceptionally $10 \mathrm{~cm}$ ) wide and often open. Some fractures were filled in by quartz but may contain the water. Clay minerals, iron or manganese oxides, sericite or fluorite coat some fracture walls while the coatings of pyrite, molybdenite or graphite are rare. Any wider dislocation zones in the granite stock are very rare. Some significant faults observed in the Slavkov gneiss roof pendant do not continue into the granite stock.

\section{Deposits of the Krásno ore district}

\section{The Huber stock deposit}

The granite of the Huber stock probably contains the largest quantities of tin in the whole region. The stock is bellshaped in section or similar to a blunt cone (Fig. 17). At
Fig. 17 A section of Huber and Schnöd granite stocks, view in direction SW-NE [P. Ondruš according to Beran (1999)].

1 - YIC granites;

2 - greisenized granites;

3 - paragneisses;

4 - cave-in parts of greisen stocks and their envelope.

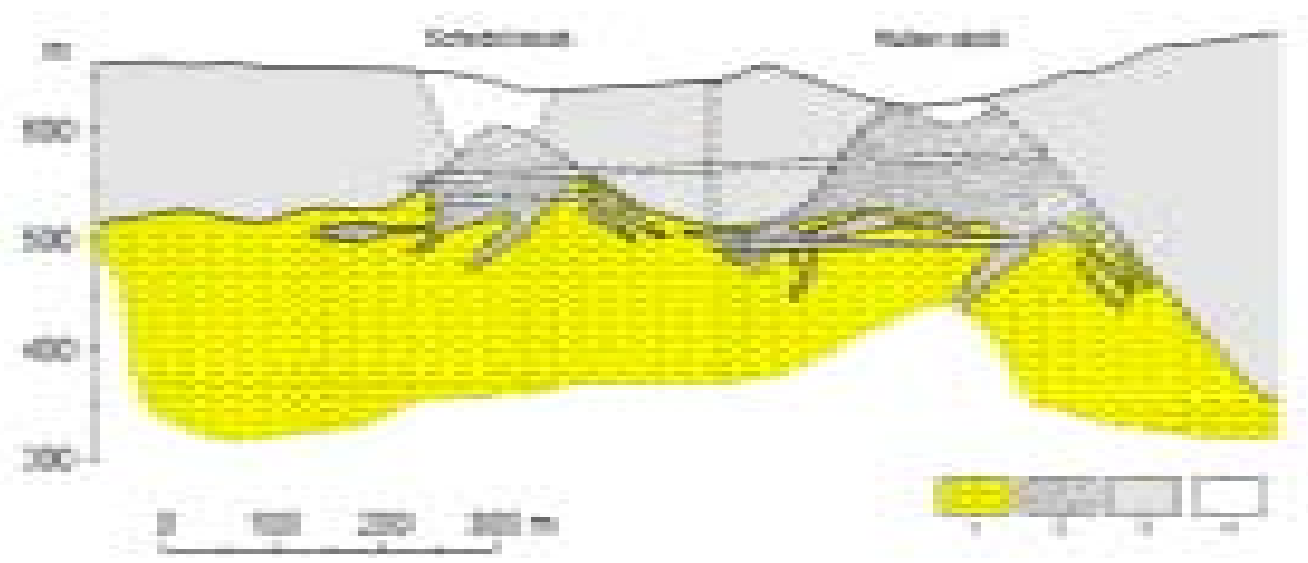


the $3^{\text {rd }}$ level, the size is $200 \mathrm{~m} \times 100 \mathrm{~m}$. At the $4^{\text {th }}$ level the stock extends $400 \mathrm{~m} \mathrm{NE}-\mathrm{SW}$ and it is about $250 \mathrm{~m}$ wide.

The Huber stock consists basically of autometamorphosed Li-mica-topaz granite with a variable degree of secondary alterations. These alterations include greisenization. It is assumed that the whole apical part of the cupola (now collapsed) was formed by greisen and quartz. Greisen also contours the endocontact of the stock. Zoning is not clearly defined and greisen passes gradually into the granite. Continuous greisen bodies may split into several lenses giving way to greinized granite and at deeper levels to unaltered Li-mica-topaz granite.

Three genetically distinct greisen types are recognized: - greisen bodies in endocontact formed probably along a network of fine fractures, free of infillings or a zoning, which pass to the granite;

- greisen bodies formed along thin, isolated fractures and sets of parallel fractures, accompanied by a distinct greisen zoning. Greisen is in places symmetrically zoned along the fluid conduits, with the strongest alteration next to the conduit. This type of greisen is typical for the central parts of the stock;

- greisens along the quartz veins are usually symmetric to the strike of the vein.

Towards deeper levels, the number of quartz veins with Sn-W mineralization and accompanying greisen declines. At a depth of 200-300 m, there are 20-40 m thick lenses with fine-grained cassiterite. The data indicate that in the near-contact zone of the Huber stock Sn-W ores continue several hundred $\mathrm{m}$ below the $4^{\text {th }}$ level of the Huber shaft but in the central part of the stock such ores do not extend below this level. Dispersed cassiterite and wolframite in all rock types represent the ore minerals. As, $\mathrm{Cu}$ and $\mathrm{Zn}$ mineralization joins the $\mathrm{Sn}-\mathrm{W}$ minerals in the apical parts of the stock. The contents of tin and tungsten vary from traces to tens of wt. \%. During mining the ore grade could not be determined by macroscopic criteria and all samples had to be analysed chemically.

Mineralization in some parts of the stock (generally above the $5^{\text {th }}$ level) occurs closely near the contact. Elsewhere, it is separated from the contact by a barren zone up to $30 \mathrm{~m}$ wide. It is assumed that the width of the barren zone increases with depth (Kozubek et al. 1985). The vertical asymmetry in position of mineralized endocontact zones is interpreted as resulting from the channels supplying the metals. The deepest extension of mineralization was at the NE (Kozubek et al. 1985).

Exploration indicates that the mineralization in the Huber stock continues to deeper levels. The morphology of granite contact with the roof rocks is decisive in the control of ore zones. This "deep level" mineralization occurs at the SW, N and NE margins of the stock. In addition to various types of Li-mica-topaz granite, below the $5^{\text {th }}$ level occur several types of two-mica granite. The contacts between individual granite types are irregular and modified by superimposed alterations. Mineralization is represented by dispersed cassiterite and wolframite in all granite types, and exceptionally also in exocontact metamorphic rocks. A preferential association with a single granite type has not been documented.

A specific feature of the Huber stock is the existence of so-called "cave-in reserves", resulting from ancient mining and a collapse of the chambers in the upper parts of the stock.

The cave-in fill is a heterogenous mixture of all rocks types including some metamorphic country rocks and crushed remains of the support pillars. Circulating water brought sand and clay material from weathered rocks into its free spaces. This compacted material was difficult to be penetrated during excavation of mine galleries or by drilling.

Numerous quartz veins intersect the Huber stock and are accompanied by 1 to $4 \mathrm{~m}$ wide wall rock greisens (Drozen 1965). Archive data indicate the four types of Sn-bearing quartz veins:

- the oldest quartz veins with wall rock greisen, which do not show mutual displacement at intersections, but are displaced at the intersection with younger veins (examples: František, Karel, Hubská, Pinková, Panská, Messer, and Tscherper veins);

- quartz veins containing clay infilling usually free of a greisen border and displacing the older veins. Examples include the Starohubská and Červená veins; - quartz veins with imperfect greisen borders, of no economic significance. The Kophan vein and a number of unnamed veins belong to this group;

- tectonic fractures filled by clay, but rarely showing mineralization. They had minimal importance in mining. Examples include the Červená fracture and Červená offshoot.

\section{The Schnöd stock deposit}

The mineralization in this stock does not reach the $4^{\text {th }}$ level in the Huber shaft. The lowest limit of mineralization is slightly above the lowest exploitation $\mathrm{X}^{\text {th }}$ level of the Vilém shaft. The Schnöd stock was explored in a more detail during the last decades, as the upper levels were less affected by ancient mining. Even so, there are not sufficient data on apical part of the stock, $70 \mathrm{~m}$ below the present surface (Fig. 17).

The envelope of this stock is built by fine- to medium-grained migmatized biotite paragneisses. The complex contains aplites and tourmaline pegmatites in proximity of the stock. The endocontact pegmatite (stockscheider) is thickest in the apical part. It contains large crystals of pink orthoclase oriented perpendicular to contact plane. At the contact with paragneiss, the orthoclase crystals are smaller and are accompanied by micas. The boundary with granite is gradational.

Medium-grained and pink granite, which builds the stock, is often affected by secondary alterations. Albite granite is widespread in the upper parts of the elongated granite elevation and in the lower part of the Schnöd stock at transition of greisen to granite. Greisens in the 
Schnöd stock are usually fine-grained or medium-grained and rich in quartz. At places, the stock contains partly greisenized and kaolinized granite with the Sn contents lower than those in typical greisen. This type of granite is developed at the upper levels only in the eastern part of the stock, but at the VIII ${ }^{\text {th }}$ level it is rather widespread throughout.

\section{Deposit to the northwest of the Huber and Schnöd stocks}

Janečka (1973) explored a flat granite elevation trending NE-SW, with economic tin mineralization. The long axis of the elevation is nearly $500 \mathrm{~m}$ long and the transversal axis at an altitude of the $4^{\text {th }}$ level of the Huber shaft is $170 \mathrm{~m}$ long. The elevation consists of albite-Li-mica-topaz granite and greisenized granite with a considerable proportion of greisen. The greisens are either composed of quartz-mica-topaz or of nearly pure quartz or quartz-topaz.

The mineralized lenses are from 5 to $30 \mathrm{~m}$ thick and they continue below the $4^{\text {th }}$ level. At the southwest, exploration documented the presence of flat mineralized lenses only 3 to $7 \mathrm{~m}$ thick at an altitude of $500 \mathrm{~m}$ a.s.1. In the upper parts, usually above the greisen horizons, fine-grained mineralized granite shows a typical banded structure and it is usually kaolinized and sericitized or silicified at places.

In the area NW of the Krásno deposit, two-mica granite occurs directly above albite granite (Kozubek et al. 1989). Marginal pegmatite (stockscheider) is composed mainly of feldspar with lesser quartz and is developed direcly at the top of this granite as a prominent $4 \mathrm{~m}$ thick body. Biotite in stockscheider forms characteristic rims at contact with the country rocks. The contact plane of the intrusion is flat, from $15-25^{\circ}$ to nearly horizontal.

\section{Gellnauer vein}

The set of tin-bearing veins includes the Gellnauer vein, succeeded upwards by the Marie vein and the Puklinová (Kluftgang) vein. The veins are parallel and follow the trend joining the stocks but they dip toward the stocks, i.e., to the NW. The veins are accompanied at the SW by the perpedicular Antonín vein. Additional veins include the Trojičná, Ondřejská, and Nepomuckého veins. The veins carried high Sn contents in their upper parts but the metal content quickly declined with increasing depth. At the VIII ${ }^{\text {th }}$ level of the Vilém shaft $(509 \mathrm{~m}$ a.s.1.), the Gellnauer vein is thin and weakly mineralized. The quartz veins with $\mathrm{Sn}$ and $\mathrm{W}$ are known to continue along strike for a distance of $800 \mathrm{~m}$. The Gellnauer and Marie veins have a moderate dip of $25-35^{\circ}$ at the upper levels but they steepen down (below the sixth level) to $35-55^{\circ} \mathrm{dips}$. The Gellnauer vein splits at the upper levels to several offshoots, which unite at the $\mathrm{VI}^{\text {th }}$ level to a single vein. It is slightly offset by transversal dislocations but rare parallel dislocations are also present. The width of the vein is reduced in granite: at the upper level the vein is
$30-40 \mathrm{~cm}$ wide but in granite at the VIII ${ }^{\text {th }}$ level it is decreased to $5-20 \mathrm{~cm}$. At lower levels, granite and also marginal pegmatite are greisenized along the vein margin but greisen border becomes narrow in gneiss.

The Gellnauer vein is characterized by massive mineral infilling and comb structure of quartz. Parallel-banded structures are absent. The ore minerals occur at the margins in the broader parts of the vein and rich mineralization correlates with a strong alteration of wall rock. The greisenization zones, or zwitter bands in gneiss, retain a regular width even along narrow veinlets and often coalesce into a single, wide band of greisenization (Janečka 1964). Greisenization in the footwall is usually wider than that in the hanging wall. Recent exploration followed the continuation of the veins from the historical area to the SE. The exploration revealed six structures corresponding to a direct continuation of veins from the historical district.

\section{Gellnauer elevation (area southeast of the Schnöd stock)}

A flat elevation of Li-mica-topaz granite with disseminated mineralization and greisenization in the area southeast of the "root zone" of the Gellnauer vein system. According to the geological position, this elevation is similar to the main stocks at Krásno. The contact of Limica-topaz granite with the gneiss dips steeply below the $4^{\text {th }}$ level of the Huber shaft, at places the contact is partly overhanging but it turns to a moderate dip at this small elevation. This cusp has its axis orientated parallel with the direction of the Huber and Schnöd stocks. The granite is medium-grained, kaolinized, hematitized, and silicified. Lenses of medium-grained mica-bearing greisen or a rare quartz-rich greisen occur at the SE. These rocks are petrographically comparable with those from the Huber stock. Endocontact greisen is absent at the SW margin, which shows a steep dip. In the endocontact of the Huber stock the Gellnauer vein system wedges-out over a short distance from the granite contact.

\section{Lánský dvůr elevation}

A small, elongated granite elevation east of the Huber stock is trending SW-NE and slightly plunging to the NE. The ore mineralization occurs at the southwestern flank but it is absent in the apical part. Ore minerals are in Limica-topaz granite, its greisenized portions and in greisen (Najman 1990). At this deposit, contacts appear to be largely tectonic. Marginal pegmatite was not observed.

\section{Area to the South and southeast of the Huber stock}

The geological situation is similar to the neighbouring areas. Contact beetween the granite and the envelope is usually rimmed by a marginal pegmatite (stockscheider) and less commonly it is a tectonic or a sharp intrusive contact. Typical granite above the mineralized lenses is 
a medium-grained Li-mica-topaz granite of the Čistá Krásno-type, less commonly occur fine-grained or porphyritic varieties. The Milíre granite is very rare. Mineralization associates with the granites, topaz-mica-quartz and mica-quartz greisens. The area to the SE of the $\mathrm{Hu}-$ ber stock has the granite structure unfavourable for $\mathrm{Sn}$ mineralization (Najman 1990). The northern part contains mineralized horizons to a depth of 450 a.s.1. The ore is associated with greisens and Li-mica-topaz granite affected by greisenization of a variable intensity. The ore body is 3 to $70 \mathrm{~m}$ thick and follows conformably the relief of granite contact. The ore horizon shows local blows and notable increases in $\mathrm{Sn}$ and $\mathrm{W}$ contents.

\section{Genesis of Sn-W deposits}

Drozen (1969) studied genesis of greisens and veins at Krásno. According to the classification by Smirnov (1983), the Krásno deposit belongs to endogenic and hydrothermal greisen deposits. In a modified classification by Havelka (1985) the deposit is classified as magmatogenic hydrothermal metasomatic deposit of greisen type. Greisen alteration was accompanied by precipitation of the ore minerals along open fractures of variable dimensions. The components were transported via hydrothermal solutions carrying fluorine, lithium, ore elements and some components released from country rocks. The mineralization process was characterized by gradual decrease of temperature and pressure and by the change in the concentration of components in ore-bearing solutions. This resulted in a series of mineral assemblages corresponding to certain stages in the deposit formation. All authors who studied genesis of these deposits (e.g., Jarchovský 1962, Drozen 1965, 1969), agree on a multi-staged process of mineralization with some overlap of individual stages in various parts of the deposit.

There is a diversity of views about the sequence of mineralization stages and relations between mineralization and greisenization. Under favourable lithological and tectonic conditions, precipitation of ore minerals was accompanied by greisenization. In most cases, there is good correlation in associations of vein filling and greisens, which point to their close relations in the process of deposition from the same batch of solutions. Mineralized greisens show irregular distribution of ore minerals and some greisen bodies or their parts are barren. Ore minerals are sometimes accumulated along certain preferential lines indicating tectonic controls, however, the control of mineralization by tectonic factors cannot be evidenced in most cases. The import of ore elements is not a single event as the ore minerals, especially cassiterite, precipited also later together with sulfides (Kušnír Jarchovský 1967). Probably, the youngest episodes of tin import are not accompanied by greisenization and cassiterite occurs also in altered granite. However, this does not prove an independence from the greisenization process (Kozubek et al. 1985).
According to some authors (Štemprok 1985, Drozen 1965, 1969, Durišová 1984 a.o.), it is more probable that an independent tin import period occurred, overlapping with greisenization, but some cassiterite was deposited after the complete evolution of greisens. Thus, greisens remained barren at some parts. The gap between greisenization and cassiterite deposition is relatively small, as indicated by the existence of rare barren greisens. However, cassiterite deposition separately from the greisen formation is relatively significant as indicated by tin ore bodies in granites showing various stages of deuteric alteration.

Jarchovský (1962) presented a model of deposit formation. Magma of the YIC granite was relatively rich in volatile components. In the course of crystallization, plagioclase (albite-oligoclase) and later orthoclase, crystallized after precipitation of quartz. The remaining albite components with silica and fluorine concentrated in a residual liquid, which resulted in the formation of albite granite with topaz. With decreasing temperature and increasing concentration of volatile components the already precipitated minerals became unstable and underwent metasomatic replacement resulting in greisenization. In addition to these "secondary" greisens, some "primary" greisens were possibly formed via crystalization from supercritical fluids including the so-called primary rocks in the apical parts of stocks. A vertical differentiation occurred in the stocks. Primary greisen formed in the apical and marginal parts of the granite elevation. The central parts contain more or less greisenized granite or granite with other types of alteration (sericitization and kaolinization). The ore veins were deposited along fractures, which also served as channels for the release of volatile components.

\section{Mineralogy of the Krásno ore district}

The Slavkovský les area, and particularly the Krásno ore district belong to the oldest mining districts in Europe. There are several hundred published papers dealing with mineralogy, however, a complete and complex mineralogical study of this district is missing untill the present time.

\section{History of mineralogical and petrological studies}

The ore deposits have been studied by a number of notable mineralogists. The first important specialist was probably Georgius Agricola (1556). Preserved papers dated before 1850 are oriented mainly to montanistic and geological aspects (Ferber 1774, Peithner 1780, Born 1790 in Drozen 1969, Peschel 1805, Günther 1820, Zippe 1847). Specialized mineralogical studies include those of Lindacker (1791), Haidinger (1830), and Presl (1837 in Drozen 1969) dedicated to topaz and pseudomorphs after wolframite.

Kenngott (1851) described carpholite as a new mineral using the specimens from Krásno. Besides mineral 
description, the paper presents results of a goniometric study and a chemical formula based on analyses by Steinmann and Stromeyer. The publication by Krejčí (1855) contains a detailed list of minerals known then from the Horní Slavkov - Krásno area. An important paper by Nowicky (1857) brings information on petrology, mining geology, and information on minerals of quartz veins and mineralized granite stocks. A detailed topographic mineralogy of the Cheb region by Glückselig (1862) presents data on local tin deposits. Rücker (1864a) published a widely based geological and petrographic description of Horní Slavkov tin deposits. In addition to petrographic, ore mineralization, and minerogenetic characteristics (in part valid till present), the paper gives extensive information on minerals of the quartz veins and greisen stocks. Erben (1884) studied crystal morphology of cassiterite crystals. Klvaňa (1886) presented detailed descriptions of numerous minerals.

Additional papers published before 1900 include studies by Krejčí (1851), Jantsch (1853, 1854, 1858), Reuss (1854, 1863), Hochstetter (1856), Jokély (1857), Zepharovich (1857, 1864), Gehlička (1858), Rücker (1864a), Sadebeck (1869), Reyer (1880, 1881), Döll (1883), and Katzer (1892). In addition to mineralogy data, these publications bring mainly petrographic and mining geology information.

In a very interesting work, Krusch (1916) assumes mineralization in two periods and gives information on ore grades of that time ( 0.2 to 0.4 wt. \% Sn). Two classical mineralogical papers deal with topaz (Rosický 1916) and cassiterite (Heilmaier 1930). Additional informations are in papers by Gareiss (1901), Barvír (1903), Hoffmann (1903, 1904), Slavík (1903), Cornu (1905, 1906), Woldřich (1905), Ježek (1914), Frieser (1916), Groth (1916), Kettner (1917), and Kudielka (1919).

Historical studies by Bílek $(1957,1958)$ present a deep analysis of available information and via reconstruction of missing data give an integrated evaluation of the Krásno area. These data significantly contributed to renewal of mining at the Huber stock. Fiala et al. (1960) described geology and petrology of the Horní Slavkov and Krásno region based on detailed geological maps at the scale of 1 : 5000. Publications by Jarchovský $(1959,1962,1969)$ Jarchovský - Štemprok (1979), and Jarchovský - Pavlů (1980, 1991) present important data on mineralogy, geochemistry, and petrography. Drozen (1959, 1962, 1969) presented the first complex study of mineralogy and petrology of the Krásno ore district.

The publications by Fiala (1948, 1950, 1952), Vtělenský (1955), Fiala et al. (1956, 1957); Fiala - Škvor (1956), Hašlar (1956), Strunz (1957), Konta (1957), Obdržálek (1958), Kratochvíl (1960), Zemánek - Gregorová (1959), Bernardová - Poubová (1961), Tacl - Blüml (1961, 1974), and others, provide additional information on the Krásno ore district.

Relatively extensive new studies by Z. Mrázek, P. Korbel, Z. Mach, M. Fikar, T. Řídkošil, P. Beran,
V. Šrein, P. Ondruš, F. Veselovský, J. Sejkora etc., still largely await publication. Nevertheless, several papers have been published (Korbel 1983, 1991; Mach-Korbel 1990; Mach 1979; Mrázek 1981). Some of these new data have been included in the unpublished studies by Beran et al. (1989), Beran - Beranová (1995) and information without analytic data has been included in the book by Beran (1999).

\section{Mineralogy of the Krásno ore district}

Mineralization at the Krásno ore district is notably rich in mineral species present. The unpublished final report by Beran - Beranová (1995) lists 191 valid minerals. The list gives 245 names, if some old descriptions and mineral varieties are considered. After the inclusion of new data presented in this volume and revision of some older mineral descriptions, the number of described minerals in the Krásno ore district is $\mathbf{2 2 8}$ valid mineral species. Eleven probable new minerals, awaiting in part a detailed study and publication (review presented in Table 1), expand the list of minerals. Some more species will likely result from a future detailed study of incompletely known $\mathrm{Nb}$-Ta minerals and from study of primary sulfides in quartz veins and greisens, which received little attention till present.

The following text gives brief information on some "mineral classics", which are widely known from the Krásno ore district and represented in numerous mineral collections throughout world. Mineralogists of the $18^{\text {th }}$ and $19^{\text {th }}$ century used specimens of several minerals, collected in the Krásno tin mines, as ideal study material in determination of physical and compositional properties.

\section{Arsenopyrite}

Zepharovich (1857), Jantsch (1854, 1858), Nowicki (1857), Glückselig (1862) and some other authors described arsenopyrite as an abundant mineral in the district.

It was common mainly in upper levels of the deposits and arsenopyrite content steeply declined with depth. The presence of arsenopyrite was closely monitored during the modern mining, as it was a harmful component in cassiterite concentrate. Only trace amounts have been evidenced at the level of $500 \mathrm{~m}$ a.s.1. In this respect, it is interesting that a rich local arsenopyrite accumulation occured in the form of clusters several $\mathrm{cm}$ to $\mathrm{dm}$ across, over a distance of $6 \mathrm{~m}$ at the $5^{\text {th }}$ level. Arsenic contents due to arsenopyrite reached up to several wt. \% in the ore from the open pit at the Huber stock. Control analyses from this site document the highest (exceptional) content of 10 wt. \% As and an average content of 1 wt. \% As in ore.

Arsenopyrite occurrences in the district are variable, including irregular aggregates and grains bound by some crystal faces, in part striated. It is associated mainly with sphalerite and cassiterite and at other places with molybdenite, chalcopyrite, covellite and luzonite. Microscopic 
Table 1 List of mineral species occurring in the Krásno Sn-W ore district and Horní Slavkov uranium ore district.

\begin{tabular}{|c|c|c|c|c|c|c|c|c|c|c|c|c|c|}
\hline mineral & 12 & 23 & 4 & mineral & 1 & 2 & 3 & 4 & mineral & 1 & 2 & 3 & 4 \\
\hline acanthite & & $*$ & $*$ & florencite-(Ce) & & & $*$ & & pitticite & & & $*$ & \\
\hline adamite & & $*$ & & fluellite & & & $*$ & & posnjakite & & & $*$ & \\
\hline albite & $* *$ & $* *$ & & fluorapatite & & & $*$ & & powellite & $*$ & & & \\
\hline allophane & & & $*$ & fluorite & $*$ & $*$ & $*$ & $*$ & preisingerite & & & $*$ & \\
\hline almandine & & $*$ & $*$ & frondelite & & & $*$ & & proustite & & & & $*$ \\
\hline alunite & & $*$ & & galena & & & $*$ & $*$ & pseudomalachite & & & $*$ & \\
\hline andalusite & & $*$ & & goethite & $*$ & $*$ & $*$ & & psilomelane & $*$ & $*$ & $*$ & \\
\hline anglesite & & & $*$ & gorceixite & & & $*$ & & pyrargyrite & & & & $*$ \\
\hline ankerite & & $*$ & $*$ & goyazite & & & $*$ & & pyrite & & & $*$ & $*$ \\
\hline annabergite & & $*$ & $*$ & graphite & & & $*$ & $*$ & pyrrhotite & & & $*$ & $*$ \\
\hline antlerite & & $*$ & & greenockite & & & $*$ & & quartz & $*$ & $*$ & $*$ & $*$ \\
\hline apatite & $* *$ & * & $*$ & grossular & & & & $*$ & rammelsbergite & & & & $*$ \\
\hline aragonite & & $*$ & & gypsum & & $*$ & $*$ & $*$ & rockbridgeite & & & $*$ & \\
\hline arsenic & & $*$ & $*$ & halloysite & & & $*$ & & rodochrosite & & & $*$ & \\
\hline arseniosiderite & & $*$ & & hematite & $*$ & $*$ & $*$ & $*$ & rooseveltite & & & * & \\
\hline arsenolite & & & $*$ & hentschelite & & & $*$ & & russelite & & & $*$ & \\
\hline arsenopyrite & & $*$ & $*$ & hübnerite & & & $*$ & & rutherfordine & & & & $*$ \\
\hline aurichalcite & & $*$ & & chalcanthite & & & $*$ & & rutile & & & $*$ & $*$ \\
\hline autunite & $*$ & $*$ & $*$ & chalcocite & & & $*$ & $*$ & scorodite & & & $*$ & \\
\hline azurite & & $*$ & $*$ & chalcophyllite & & & $*$ & & serpierite & & & $*$ & \\
\hline barite & & $*$ & $*$ & chalcopyrite & $*$ & $*$ & $*$ & $*$ & scheelite & $*$ & & $*$ & \\
\hline bavenite & $*$ & & & chalcosiderite & & $*$ & $*$ & & schultenite & & & & $*$ \\
\hline benyacarite & & $*$ & & chenevixite & & & $*$ & & siderite & & & $*$ & $*$ \\
\hline beraunite & & $*$ & & chrysocolla & & & $*$ & & sillimanite & & & & $*$ \\
\hline bertrandite & $*$ & & & illite & & & $*$ & & silver & & & $*$ & $*$ \\
\hline beryl & $*$ & & & ilmenite & & $*$ & & & skutterudite & & & & $*$ \\
\hline betpakdalite & & $*$ & & ilsemannite & & & $*$ & & soddyite & & & & $*$ \\
\hline bindheimite & & $*$ & & isokite & & & $*$ & & sodiumuranospinite & & & & $*$ \\
\hline biotite & $* *$ & $* \quad *$ & $*$ & jarosite & & $*$ & & & sphalerite & & & $*$ & $*$ \\
\hline bismite & & $*$ & $*$ & kaatialaite & & & & $*$ & stannite & & & $*$ & $*$ \\
\hline bismuth & $*$ & $*$ & $*$ & kaňkite & & & $*$ & & stannoidite & & & $*$ & \\
\hline bismuthinite & & $*$ & $*$ & kaolinite & $*$ & $*$ & $*$ & $*$ & stibnite & & & $*$ & $*$ \\
\hline bismutite & & $*$ & & kësterite & & & $*$ & & stolzite & & & $*$ & \\
\hline bismutoferrite & & $*$ & & koechlinite & $*$ & & $*$ & & strengite & & $*$ & $*$ & \\
\hline bornite & & $*$ & $*$ & kolbeckite & $*$ & & $*$ & & talc & & & & $*$ \\
\hline brochantite & & $*$ & & kyanite & & & $*$ & $*$ & tennantite & & & $*$ & $*$ \\
\hline brookite & $*$ & & & langite & & & $*$ & & tenorite & & & $*$ & \\
\hline cacoxenite & * & $* *$ & & leucophosphite & & $*$ & $*$ & & tetrahedrite & & & $*$ & $*$ \\
\hline calcite & & $*$ & $*$ & libethenite & & & $*$ & & titanite & & & $*$ & $*$ \\
\hline cannonite & & $*$ & & liebigite & & & & $*$ & topaz & $*$ & $*$ & $*$ & $*$ \\
\hline carnotite & & & $*$ & limonite & $*$ & $*$ & $*$ & $*$ & torbernite & & & $*$ & $*$ \\
\hline carpholite & & $*$ & & linarite & & & $*$ & & tremolite & & & & $*$ \\
\hline cassiterite & $* *$ & $* \quad *$ & $*$ & löllingite & & & & $*$ & triplite & & & $*$ & \\
\hline clinoclase & & $*$ & & luzonite & & & $*$ & & triploidite & & & $*$ & \\
\hline cobaltite & & & $*$ & magnesite & & & $*$ & & tungstite & & & $*$ & \\
\hline coffinite & & & $*$ & magnetite & & $*$ & & $*$ & turquoise & & $*$ & $*$ & \\
\hline compreignacite & & & $*$ & malachite & & $*$ & $*$ & $*$ & tyrolite & & & $*$ & \\
\hline cookeite & $*$ & $*$ & & manganite & $*$ & & & & uraninite & & & & $*$ \\
\hline copper & & $*$ & $*$ & mansfieldite & & & $*$ & & uranophane & & & $*$ & $*$ \\
\hline cordierite & & & $*$ & marcasite & & & $*$ & $*$ & uranospinite & & & & $*$ \\
\hline cornwallite & & $*$ & & mawsonite & & & $*$ & & variscite & & $*$ & & \\
\hline covellite & & $*$ & $*$ & melanterite & & & $*$ & & varlamoffite & & & $*$ & \\
\hline
\end{tabular}


Table 1 (continued)

\begin{tabular}{|c|c|c|c|c|c|c|c|c|c|c|c|c|c|}
\hline mineral & 12 & 3 & 4 & mineral & 1 & 2 & 3 & 4 & mineral & 1 & 2 & 3 & 4 \\
\hline crandallite & & $*$ & & metaautunite & $*$ & $*$ & & $*$ & vermiculite & & & $*$ & \\
\hline cryptomelane & & $*$ & & metanováčekite & & & & $*$ & vesuvianite & & & $*$ & \\
\hline cubanite & & $*$ & & metatorbernite & & & $*$ & $*$ & vivianite & & $*$ & $*$ & \\
\hline cuprite & & $*$ & & metazeunerite & & & $*$ & $*$ & wavellite & & $*$ & $*$ & \\
\hline cuprosklodowskite & & & $*$ & millerite & & & & $*$ & waylandite & & & $*$ & \\
\hline cyanotrichite & & $*$ & & mixite & & & $*$ & & whitmoreite & & & $*$ & \\
\hline devillite & & $*$ & & mohrite & & & $*$ & $*$ & wittichenite & & & $*$ & \\
\hline dickite & $* *$ & $*$ & & molybdenite & & $*$ & $*$ & $*$ & wolframite & $*$ & $*$ & $*$ & $*$ \\
\hline digenite & & $*$ & & molybdite & & & $*$ & & wollastonite & & & $*$ & $*$ \\
\hline diopside & & $*$ & & monazite-Ce) & & & $*$ & & wulfenite & $*$ & & & \\
\hline dioptase & & $*$ & & montmorillonite & & & $*$ & & xenotime-(Y) & $*$ & & $*$ & \\
\hline djurleite & & $*$ & & morinite & & & $*$ & & zavaritskite & & & $*$ & \\
\hline dolomite & & $*$ & $*$ & muscovite & $*$ & $*$ & $*$ & $*$ & zeunerite & & & $*$ & $*$ \\
\hline dufrénite & & $*$ & & nacrite & & $*$ & $*$ & & zinnwaldite & & $*$ & $*$ & \\
\hline dumortierite & & $*$ & & natrodufrénite & & & $*$ & & zippeite & & & $*$ & $*$ \\
\hline dussertite & & $*$ & & natrojarosite & & & $*$ & & zircon & $*$ & & $*$ & \\
\hline earlshannonite & & $*$ & & nickeline & & & & $*$ & zwieselite & & & $*$ & \\
\hline emplectite & & $*$ & & nickel-skutterudite & & & $*$ & $*$ & UNK1 & & & $*$ & \\
\hline epidote & & $*$ & $*$ & nováčekite & & & & $*$ & UNK2 & & & $*$ & \\
\hline erythrite & & $*$ & $*$ & olivenite & & & $*$ & & UNK3 & & & $*$ & \\
\hline euchroite & & $*$ & & opal & & & & $*$ & UNK4 & & & $*$ & \\
\hline eulytite & & & $*$ & orthoclase & $*$ & $*$ & $*$ & $*$ & UNK5 & & & & $*$ \\
\hline euxenite-(Y) & $*$ & & & petitjeanite & & & $*$ & & UNK6 & & & $*$ & \\
\hline ferberite & & $*$ & & pharmacolite & & & $*$ & $*$ & UNK7 & & & $*$ & \\
\hline ferrimolybdite & & $*$ & & pharmacosiderite & & & $*$ & & UNK8 & & & $*$ & \\
\hline ferritungstite & & $*$ & & phenakite & $*$ & & & & UNK9 & & & $*$ & \\
\hline ferrocarpholite & & $*$ & & phlogopite & & $*$ & $*$ & & UNK10 & & & $*$ & \\
\hline ferrocolumbite & $*$ & $*$ & & phosphosiderite & & & $*$ & & UNK11 & & & $*$ & \\
\hline ferrotapiolite & $*$ & & & phosphuranylite & & & & $*$ & & & & & \\
\hline
\end{tabular}

1 - Vysoký Kámen (feldspar) deposit (Sejkora et al. 2006a); 2 - Vysoký Kámen (greisen) locality (Sejkora et al. 2006a); 3 - Huber and Schnöd stock, Gellnauer vein system, Krásno (Sejkora et al. 2006b, c, d); 4 - Horní Slavkov uranium ore district (Plášil et al. 2006, Sejkora et al. 2006c). Minerals studied during the present project are shown by bold print (Sejkora et al. 2006a-d; Plášil et al. 2006).

intergrowths of arsenopyrite with the enumerated minerals also occur. Cavities with arsenopyrite contain younger clay minerals and fluorite. Arsenopyrite is usually lead grey with bluish iridiscent colour and silver grey with metallic lustre on fresh fractures. It has been commonly found in grains of about $1 \mathrm{~cm}$ in size, often partly affected by supergene alteration. Exceptionally well-formed crystals (Fig. 18), up to $5 \mathrm{~cm}$ long, occurred in the cavities of quartz veins in the outcrops of the Huber stock. Arsenopyrite from these localities is associated with quartz grading to rock crystal and sulfides.

\section{Carpholite}

Carpholite (Figs 19 and 20) is a relatively rare mineral at these deposits. Specimens from Krásno served as a type material on which Kenngott (1851) described this species as a new mineral. Gehlička (1858), Glückselig (1862) and Klvaňa (1886) also described carpholite occurrences in the district. Documented finds include VIII $^{\text {th }}$ to $\mathrm{X}^{\text {th }}$ level in the central part of the Schnöd stock and the area of inclined tunnel between the $4^{\text {th }}$ level and a site at the level of $500 \mathrm{~m}$ a.s.1. Besides these places, carpholite also occurred in the Huber open pit and at the $4^{\text {th }}$ level in association with hübnerite.

At the VIII ${ }^{\text {th }}$ level of the Schnöd stock, there was a cluster of carpholite veins up to $10 \mathrm{~cm}$ wide. The mineral is associated with siderite, fluorite, and rare Fe-rich carpholite. The marginal parts of veins carried hübnerite. The largest occurrence of carpholite is between the IX ${ }^{\text {th }}$ and $X^{\text {th }}$ level of the Schnöd stock. The veins intersect both levels. The widest veins measured $15 \mathrm{~cm}$ while the common width was $1 \mathrm{~cm}$. Carpholite from these occurrences has a bright yellow-golden colour and is associated with rhodochrosite, fluorite, apatite, hübnerite and cassiterite.

In the so-called "Dovrchní" area, carpholite occurred in a vein with hübnerite and clay minerals in an adit at the $4^{\text {th }}$ level. The largest carpholite vein occurred at a site 


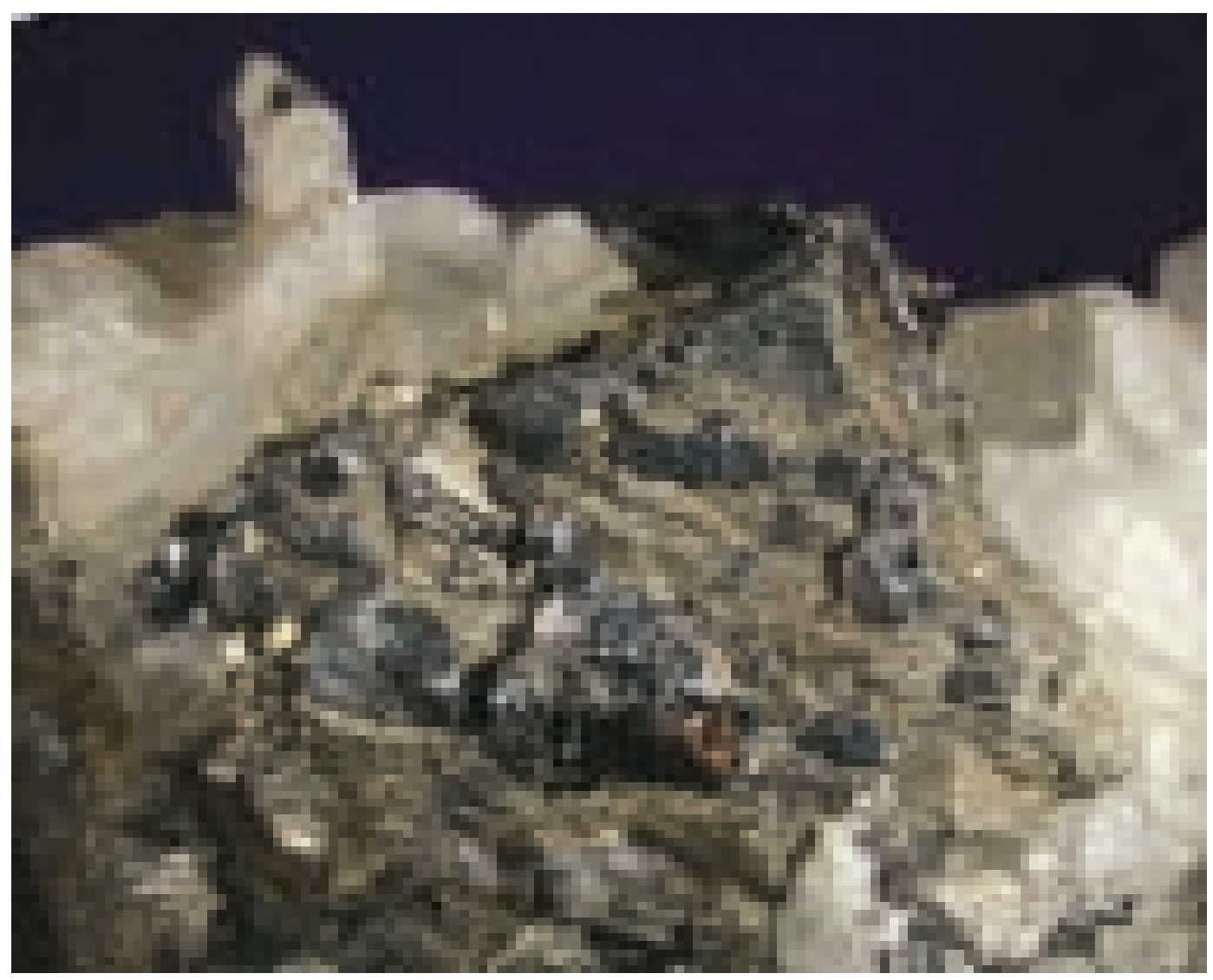

Fig. 18 Crystal of arsenopyrite in quartz gangue, Krásno near Horní Slavkov. Width of photo $3 \mathrm{~cm}$; Nicon SMZ1500 microphotography (J. \& E. Sejkora).

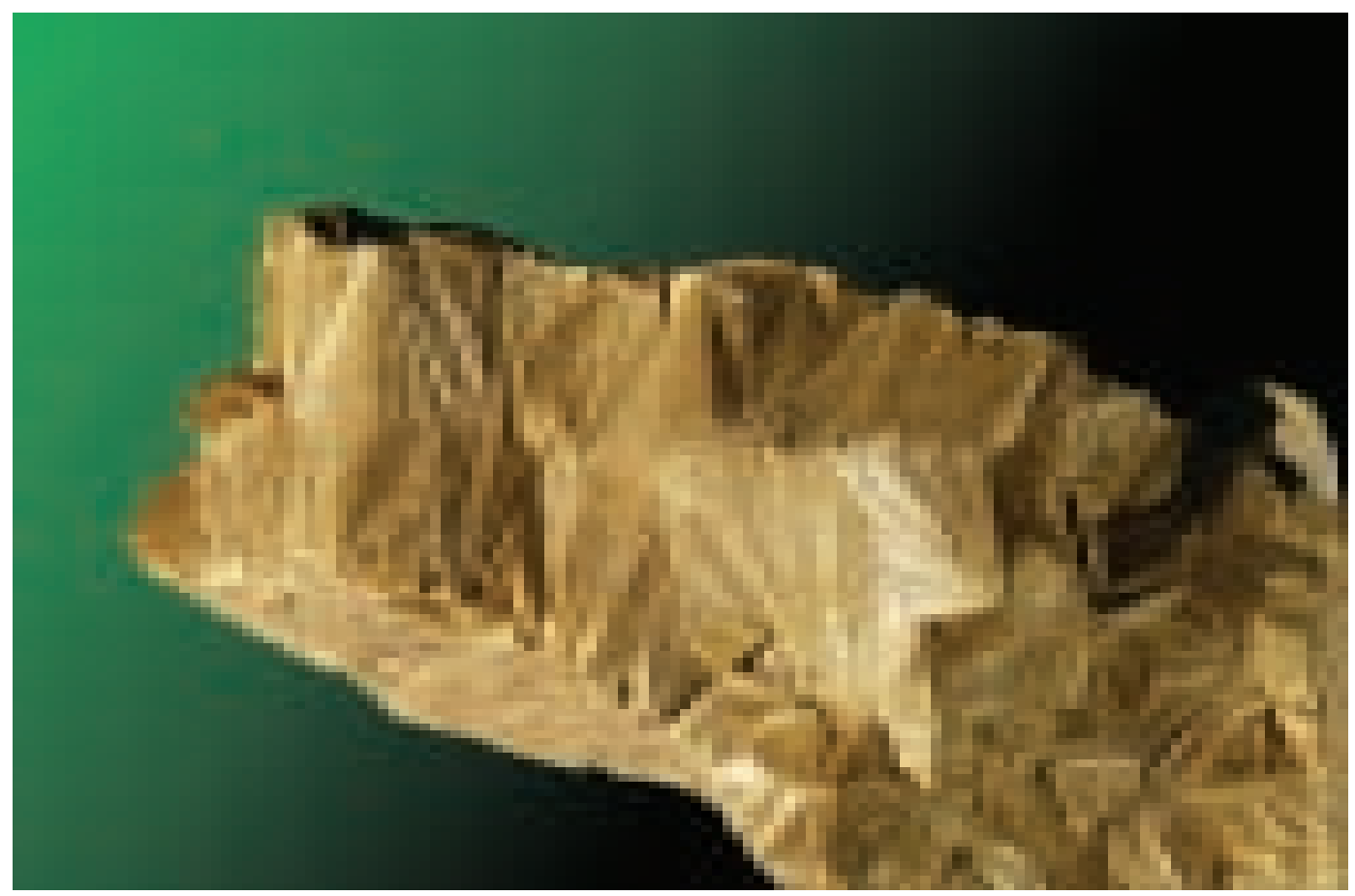

Fig. 19 Carpholite vein formed by radiating fibrous crystals, Schnöd stock, Krásno near Horní Slavkov. Width of photo $5 \mathrm{~cm}$; Canon DS1 macrophotography (J. \& E. Sejkora). 
Fig. 20 Carpholite veinlets in altered greisen rock, Schnöd stock, Krásno near Horní Slavkov. Width of photo $8 \mathrm{~cm}$; Canon DS1 macrophotography (J. \& E. Sejkora).

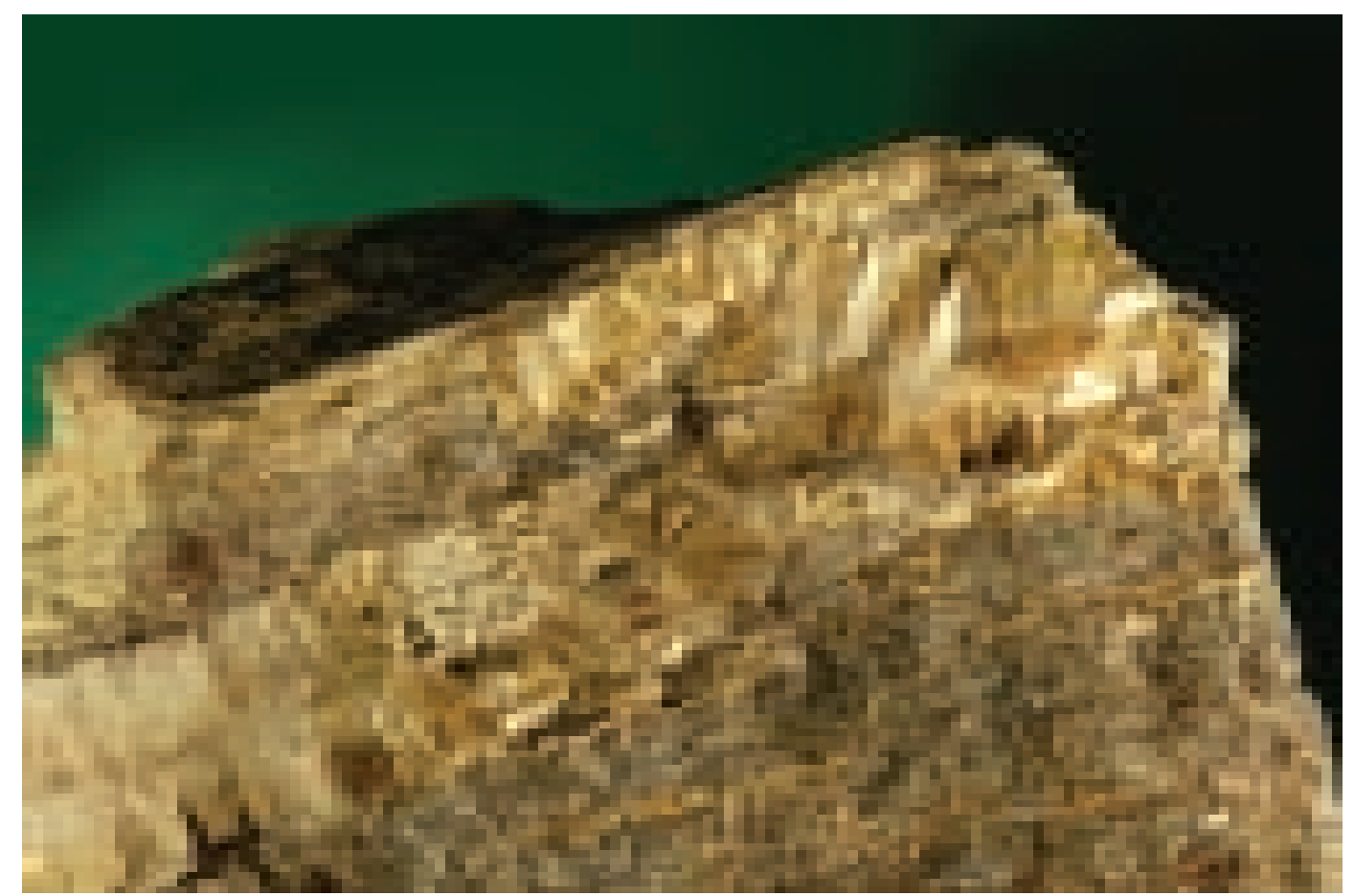

$500 \mathrm{~m}$. a.s.1. Carpholite with apatite formed $6 \mathrm{~cm}$ wide veins and radiating aggregates along country rock fractures. An exceptional find in the Kaiser shaft area at the $500 \mathrm{~m}$ level was a cavity with crystals of quartz, fluorite and apatite, which supported individual acicular carpholite crystals reaching the size up to $4 \mathrm{~cm}$.

\section{Cassiterite}

As a matter of course, all authors dealing with these deposits mention cassiterite. Detailed information on cassiterite present for example Erben (1884), Klvaňa (1886) and Heilmaier (1930). In rocks of the Huber stock, cassiterite occurs in grains from a fraction of $\mathrm{mm}$ to $2 \mathrm{~cm}$ (Drozen 1965). The mineral has a honey brown to black colour and it is transparent in thin fracture splinters with brown to red shade. It is common to see colour variation in single grains in thin section under the microscope. The crystals are highly lustrous with a vitreous to adamantine lustre. Cassiterite shows a strong tendency to euhedral crystallization in all paragenetic settings. However, the crystals are often unevenly developed. The best specimens come from quartz vein cavities and local "bonanzas" where cassiterite crystallized in clay matrix. There is hardly any record of single crystals, since cassiterite has a strong tendency to twinning (Figs 21 and 22). It forms twins in simple cases but octuplets are not rare (Figs 23 and 24). As the first genetic setting, cassiterite occurs in greisens and some altered granites in grains to $1 \mathrm{~mm}$ and often strongly fractured. The grains show locally colour zoning and lamellar deformation twinning. Macroscopic cassiterite occurs in greisens at the Huber open pit and in some coarse-grained quartz-topaz greis- ens. It is accompanied by sulfides. At other places, it represents usually a single ore component.

In the second genetic type, cassiterite occurs in quartzcassiterite and quartz-cassiterite-sulfide veins. Cassiterite forms anhedral, equant grains several $\mathrm{cm}$ in diameter. This cassiterite is usually younger than some part of the vein quartz. A special type of this mineralization is the so-called "quartz body" at position of the $3^{\text {rd }}$ level,

Fig. 21 Idealized drawing of crystal twin of cassiterite from Krásno near Horní Slavkov (according to Ježek 1932).

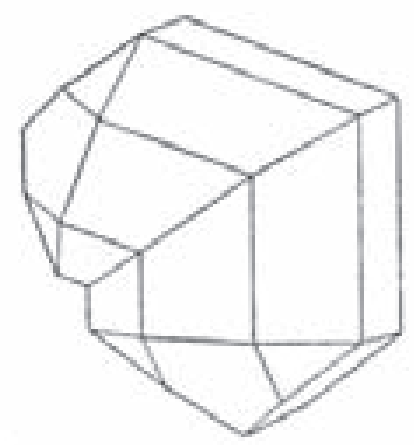

Fig. 22 Idealized drawing of cassiterite crystals showing multiple twinning from Krásno near Horní Slavkov (according to Ježek 1932).

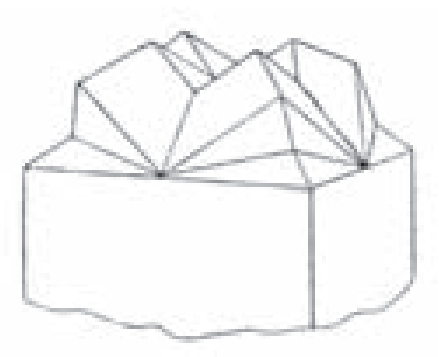




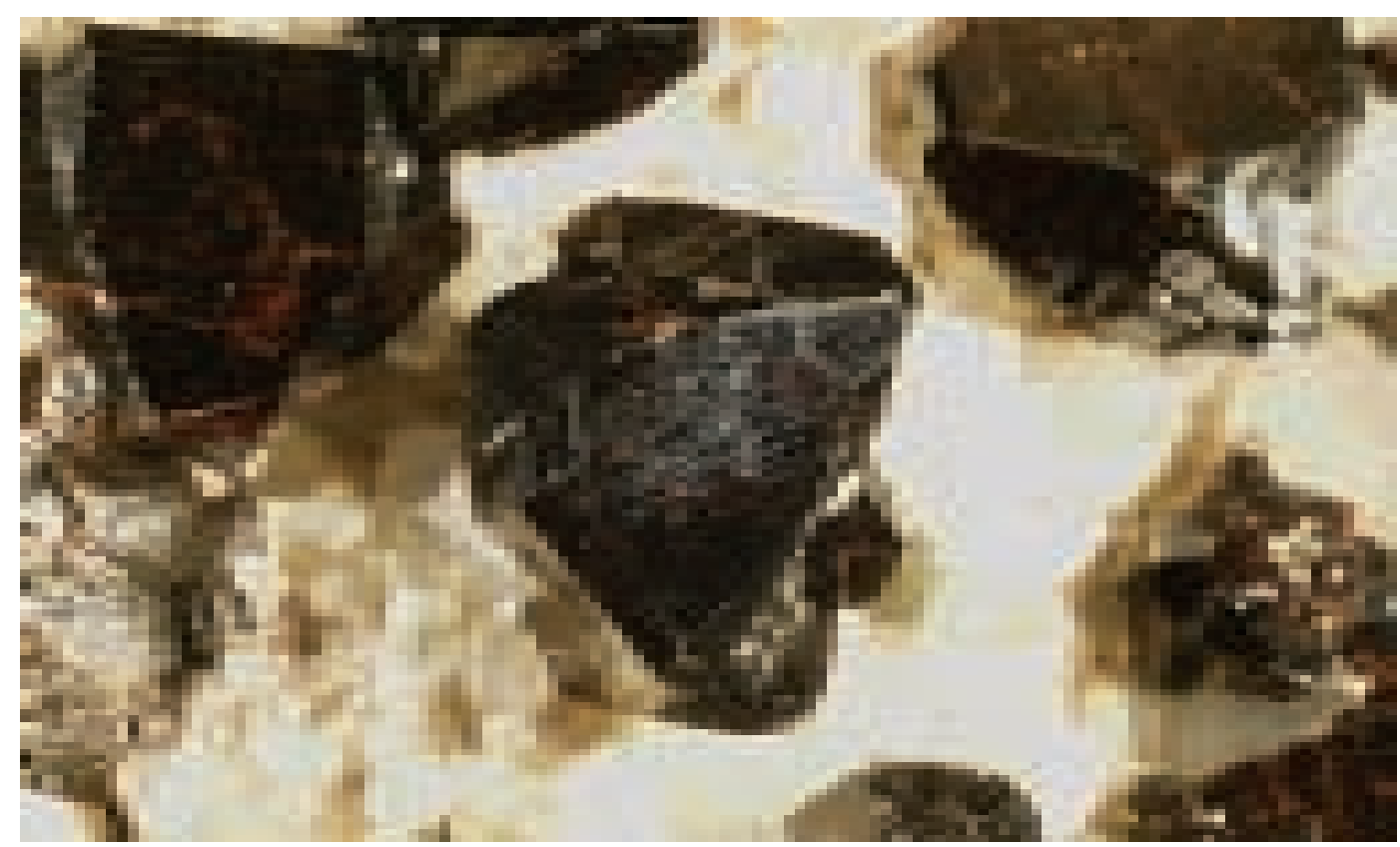

Fig. 23 Crystals of cassiterite, Krásno near Horní Slavkov. Width of photo $5 \mathrm{~cm}$; Canon DS1 macrophotography (J. \& E. Sejkora).

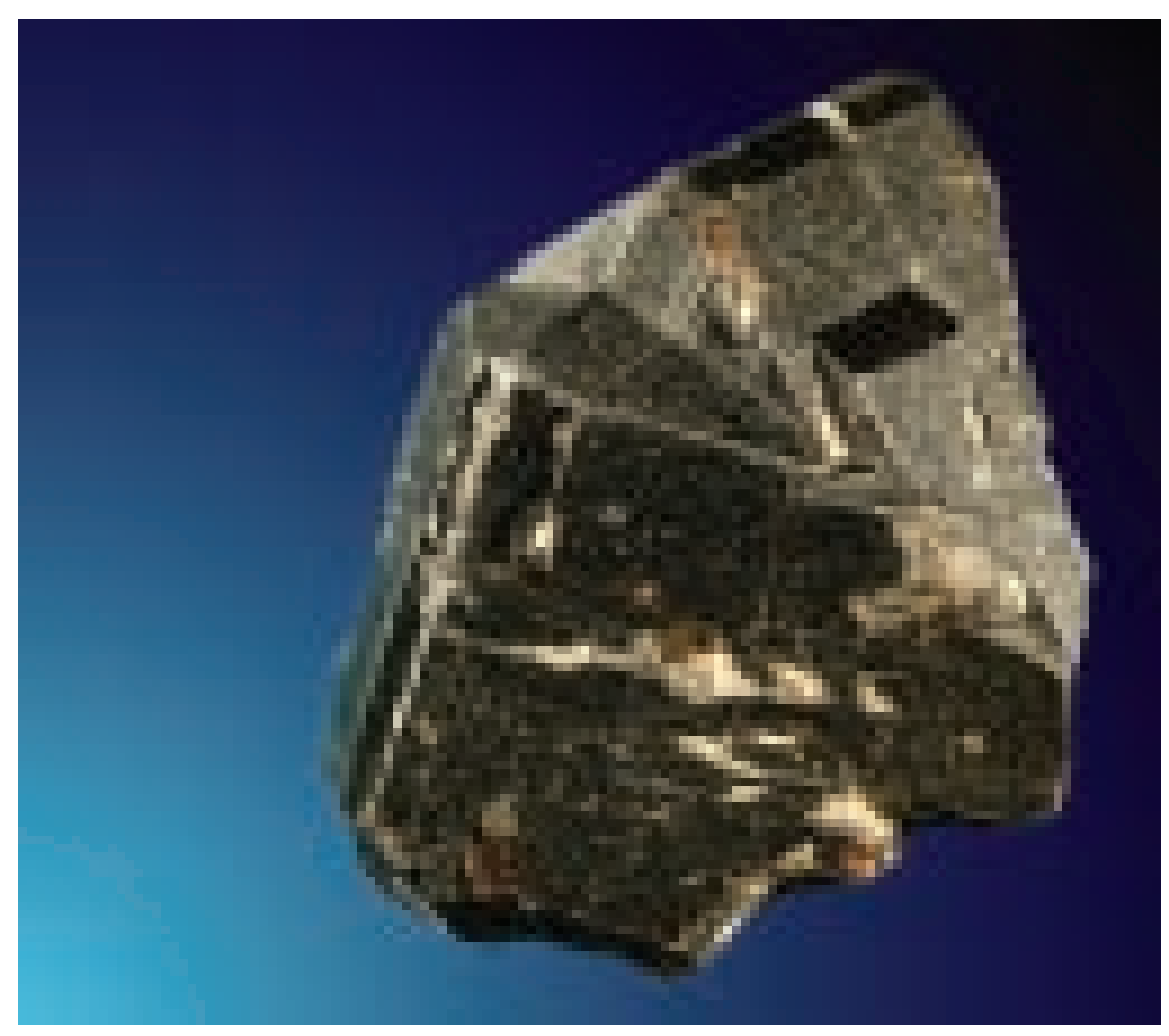

Fig. 24 Cassiterite twin crystal, Krásno near Horní Slavkov. Width of photo $5 \mathrm{~cm}$; Canon DS1 macrophotography (J. \& E. Sejkora). 
carrying dominantly quartz-wolframite mineralization. At this place, cassiterite is clearly the youngest mineral, deposited on quartz crystals in cavities.

The third type of cassiterite occurrence is in ore pocket in the so-called bonanzas. These nests of a lenticular or loaf-like shape are about $50 \mathrm{~cm}$ long and 20-30 cm thick, or exceptionally larger. They occur in greisens and rarely in greisenized granite. The open spaces are filled by a mixture of clay minerals, most frequently greenish yellow flaky dickite and cassiterite, sometimes accompanied by perfectly crystallized topaz. The mechanism of formation of these pockets is not clarified, as there are no fluid conduits observed in their vicinity.

Probably the largest cassiterite crystals occur in quartz veins, in cavities and in "bonanzas" in top parts of the stocks. Historical collections contain multiple crystal twins up to $20 \mathrm{~cm}$ in size. Loose cassiterite crystals to $5 \mathrm{~cm}$ sizes have been found during mining in numerous pockets in the last decades. Small-sized crystals (usually smaller than $2 \mathrm{~cm}$ ) were abundant in the open pit at the Huber stock. Perfect twins to $7 \mathrm{~cm}$ were rare. Also notable is find of brown cassiterite crystals to $5 \mathrm{~cm}$ in a quartz vein at the $4^{\text {th }}$ level of the Huber stock. Exceptional are specimens of light brown $1 \mathrm{~cm}$ crystals, which are transparent with some translucent areas, from quartz vein with sulfides at an extraordinary level at $500 \mathrm{~m}$ a.s.l.

\section{Chalcopyrite}

Jantsch (1854, 1858), Krejčí (1855), Glückselig (1862), Klvaňa (1886), Katzer (1892) and other authors described chalcopyrite occurrences in the district. It is widely distributed in several generations (Drozen 1965). Only some important documented finds can be mentioned here. Chal- copyrite typically occurs as impregnation with other sulfides in apical parts of the stocks. During some periods of mining chalcopyrite was dressed to chalcopyrite concentrate. With increasing depth chalcopyrite content sharply declined and no occurrence was recorded below the $4^{\text {th }}$ level of the Huber shaft.

At the Schnöd stock chalcopyrite together with sphalerite impregnated the uppermost part composed of greisen. In a similar way, chalcopyrite with arsenopyrite, sphalerite, and some other sulfides occurs in greisen at the Huber stock. The largest aggregates of compact chalcopyrite are several $\mathrm{cm}$ long, e.g. at the $\mathrm{X}^{\text {th }}$ and VIII ${ }^{\text {th }}$ levels of the Schnöd stock, at a site near $500 \mathrm{~m}$ a.s.l. of the shaft Kaiser. Quartz, sphalerite, bornite, tetrahedrite, and other minerals accompany chalcopyrite.

Crystallized chalcopyrite (Figs 25 and 26) was common in quartz veins inside the stocks as well as in the gneiss envelope. This is documented by specimens in old mineral collections, finds at old dumps behind the ventilation shaft No. 2, the dumps around the Huber stock or at the outcrop of the Gellnauer vein system. Tunneling workings on new ventilation shaft exposed veins with massive aggregates of chalcopyrite having dm sizes, with sphalerite and cassiterite. This find probably belongs to the Ondřejská vein. Chalcopyrite crystals from quartz veins are 0.5 to $1 \mathrm{~cm}$ in size and associate with fluorite, sphalerite, cassiterite, apatite, chalcedony, wolframite, and others. During modern mining of cassiterite, crystallized chalcopyrite was very rare. Crystals often carry complete coating of blue or blue-violet covellite and reach only $5 \mathrm{~mm}$ at maximum. At the $\mathrm{X}^{\text {th }}$ level of the Schnöd stock, chalcopyrite crystallized to $3 \mathrm{~mm}$ is associated with triplite, siderite, apatite, fluorite, cassiterite, topaz, and quartz.
Fig. 25 Group of chalcopyrite crystals from Krásno near Horní Slavkov. Width of photo $12 \mathrm{~cm}$; Canon DS1 macrophotography (J. \& E. Sejkora).

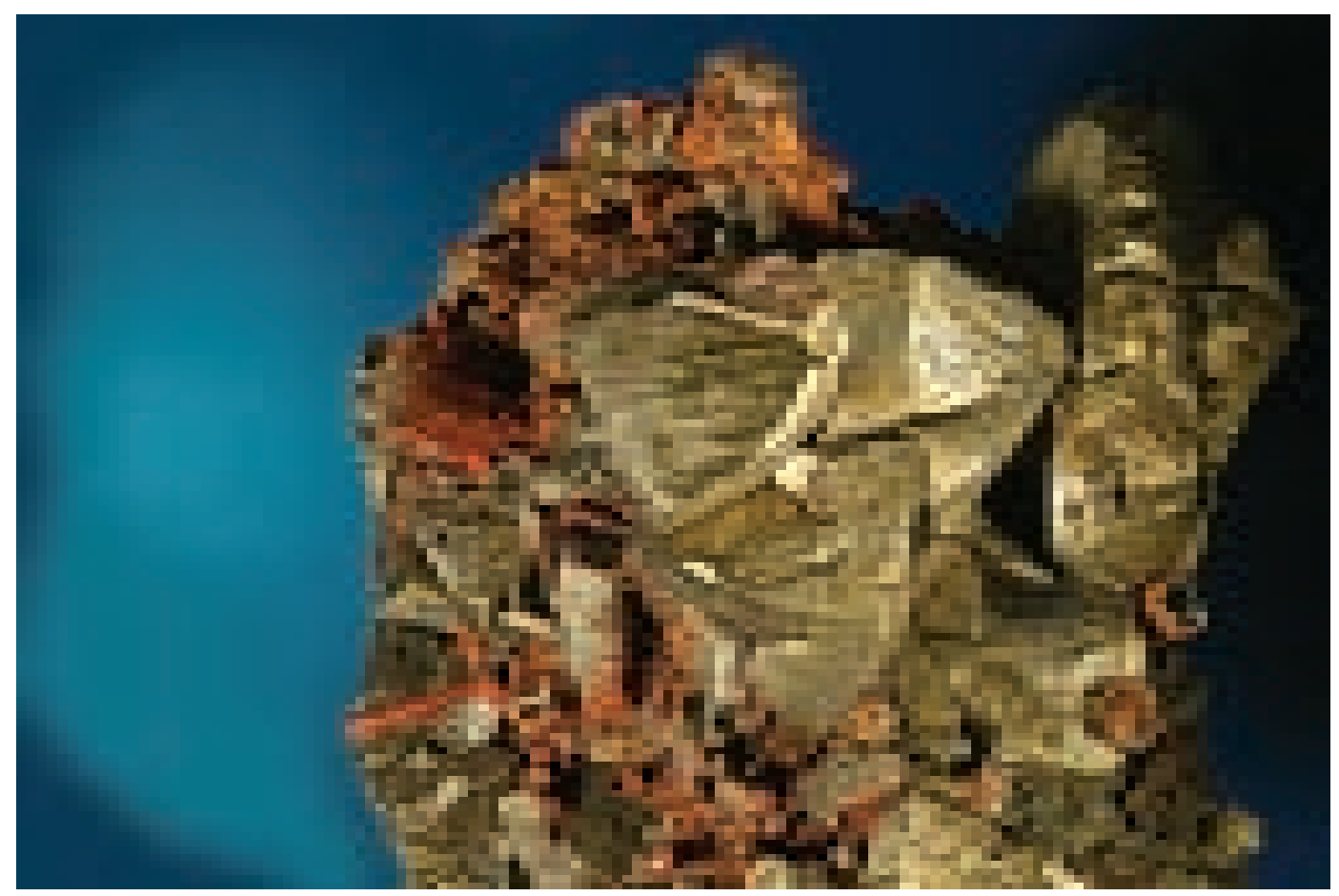




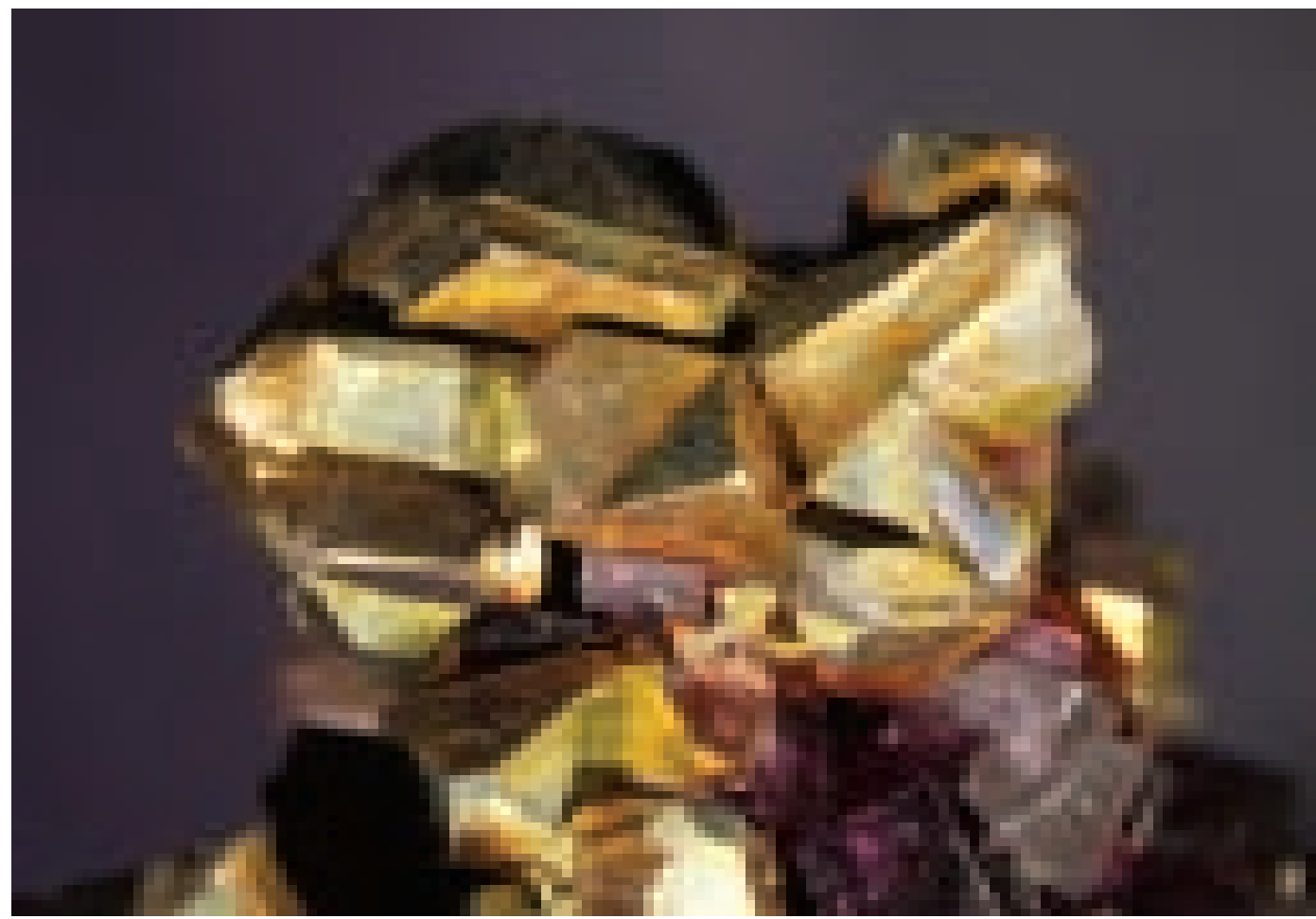

Fig. 26 Chalcopyrite crystals overgrown by violet fluorite, Krásno near Horní Slavkov. Width of photo $1.1 \mathrm{~cm}$; Nicon SMZ1500 microphotography (J. \& E. Sejkora).

\section{Fluorapatite}

It belongs to minerals widely known from the district. It is mentioned already by Zippe (1847), Jantsch (1853, 1854), and Glückselig (1862). Several types of fluorapatite occur in various mineral associations.

Rock-forming fluorapatite is a primary accessory mineral in tin-bearing granite. It occurs in subhedral crystals enclosed in mica or some other minerals. A "hydrothermal" fluorapatite is anhedral and it occurs in relatively larger grains in greisens or altered mineralized granite. Fluorapatite in cavities of greisen forms macroscopic compact and irregular infillings of red-brown to brown colour. On microscopic scale, granular aggregate or an aggregate of well-formed small crystals are observed, which are often associated with fluorite. In

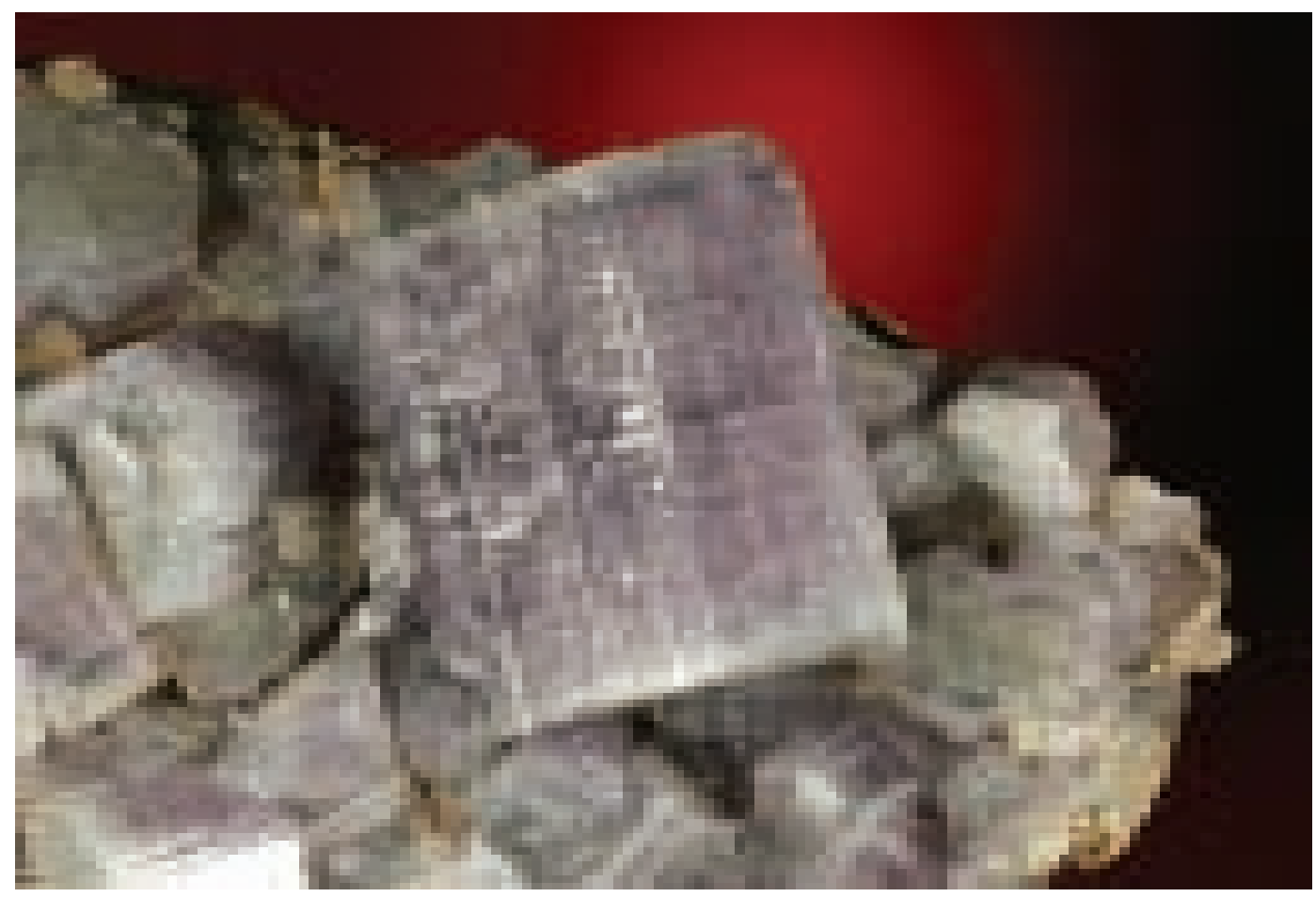

Fig. 27 Fluorapatite crystals in cavity of quartz gangue, Krásno near Horní Slavkov. Width of photo $7 \mathrm{~cm}$; Canon DS1 macrophotography (J. \& E. Sejkora). 
places, the masses are porous and coated by small macroscopic crystals.

Of mineralogical interest are nearly perfectly formed crystals up to $2 \mathrm{~cm}$ large in cavities of quartz veins (Figs
27-31). They are often associated with cassiterite and sulfides. Their colour ranges from green and yellow, through pink, violet, blue and brown to colourless. Crystal habitus is prismatic to lenticular, with a large number

Fig. 28 Group of fluorapatite crystals on partly weathered quartz gangue, Krásno near Horní Slavkov. Width of photo $12 \mathrm{~cm}$; Canon DS1 macrophotography (J. \& E. Sejkora).

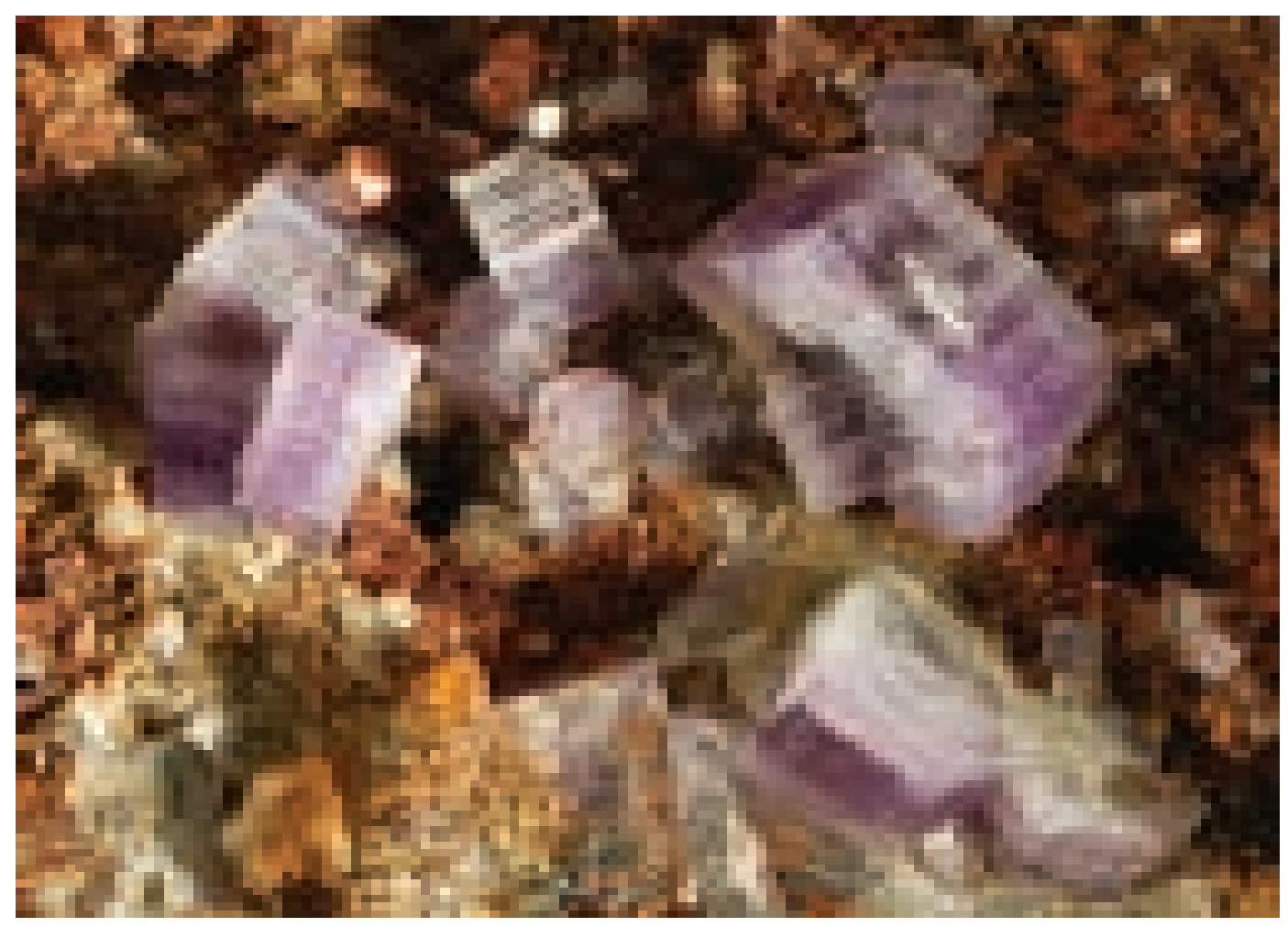

Fig. 29 Fluorapatite crystals on quartz gangue, Krásno near Horní Slavkov. Width of photo $1.1 \mathrm{~cm}$; Nicon SMZ1500 microphotography (J. \& E. Sejkora).

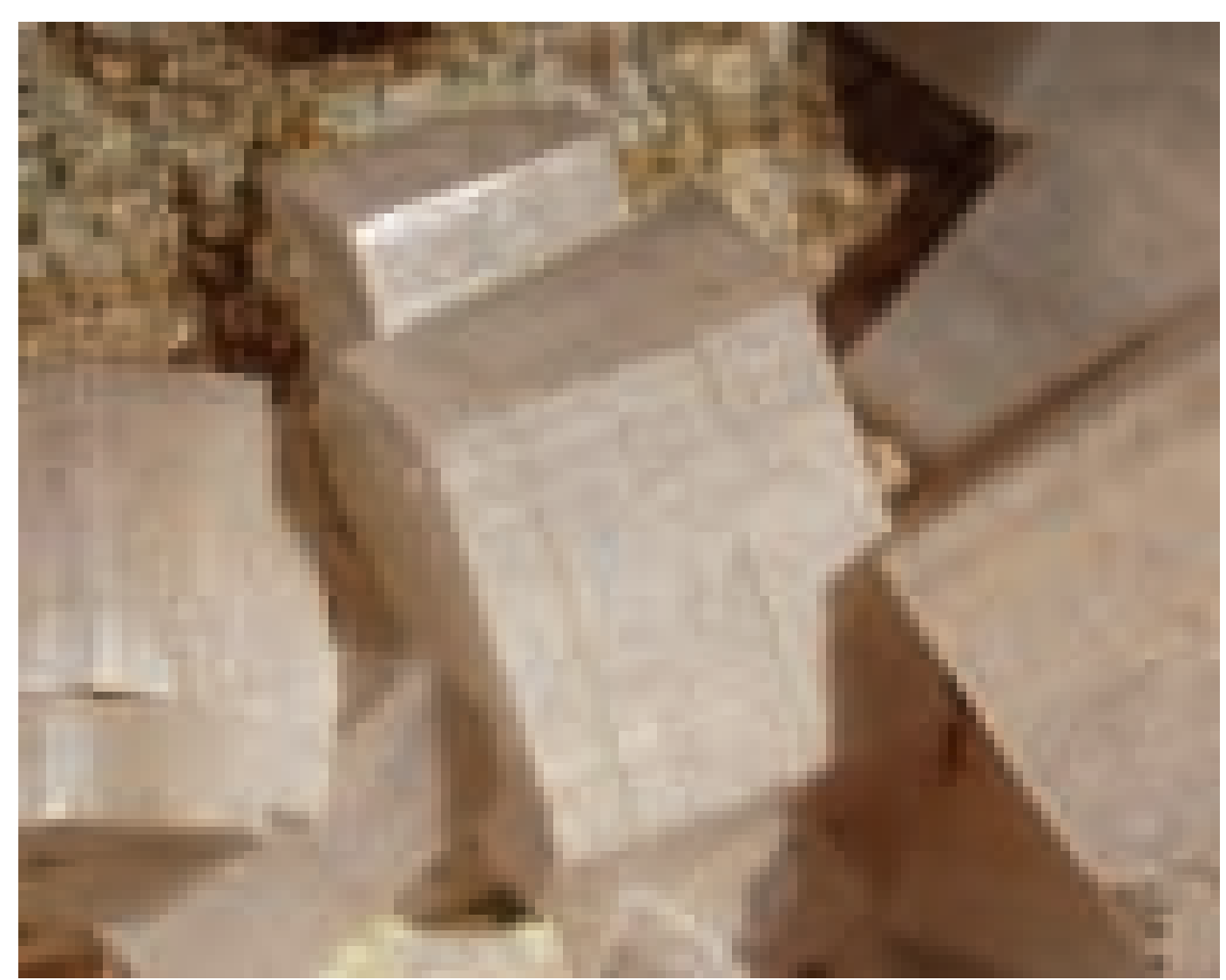




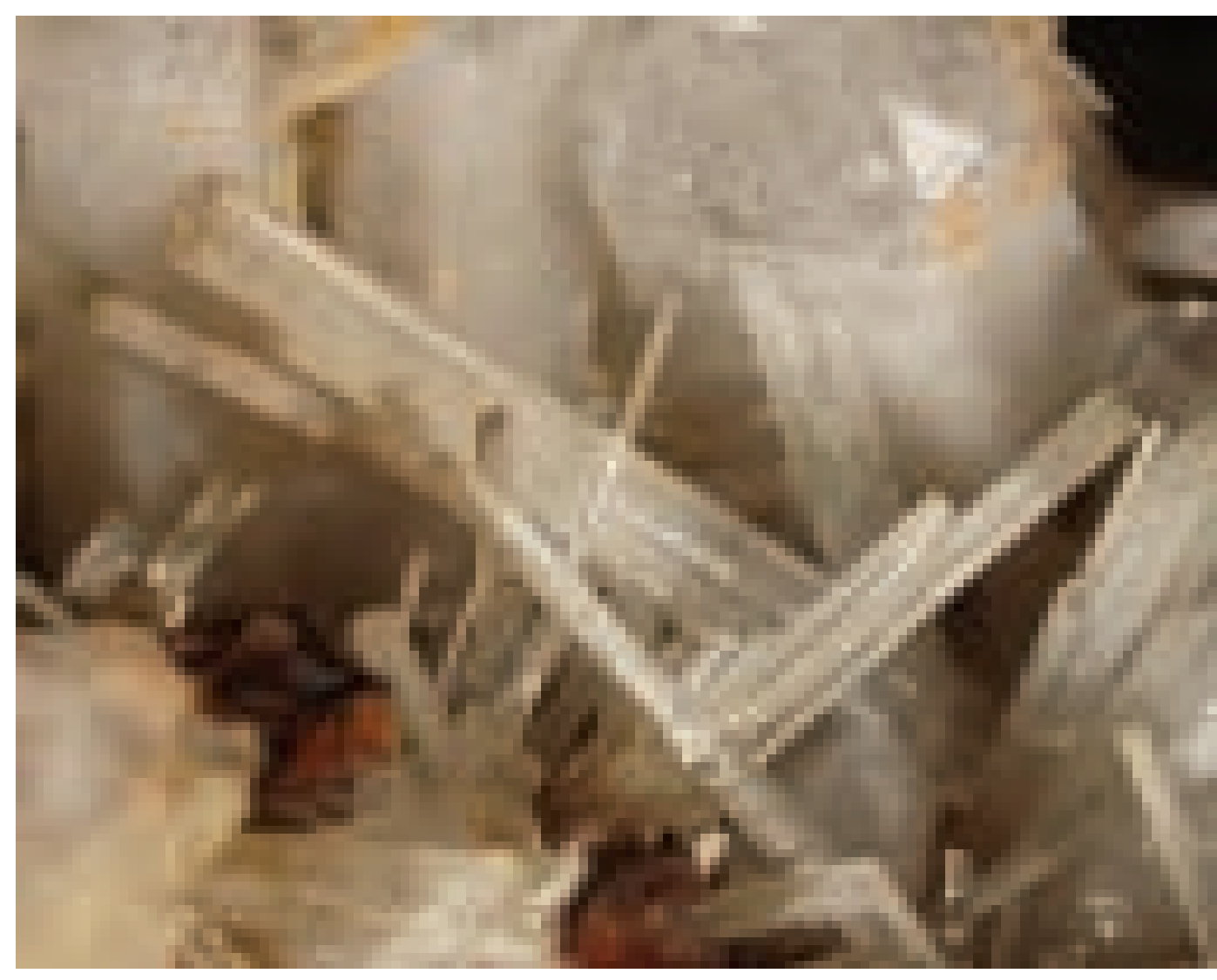

Fig. 30 White columnar crystals of fluorapatite in cavity of quartz gangue, Krásno near Horní Slavkov. Width of photo $9 \mathrm{~mm}$; Nicon SMZ1500 microphotography (J. \& E. Sejkora).

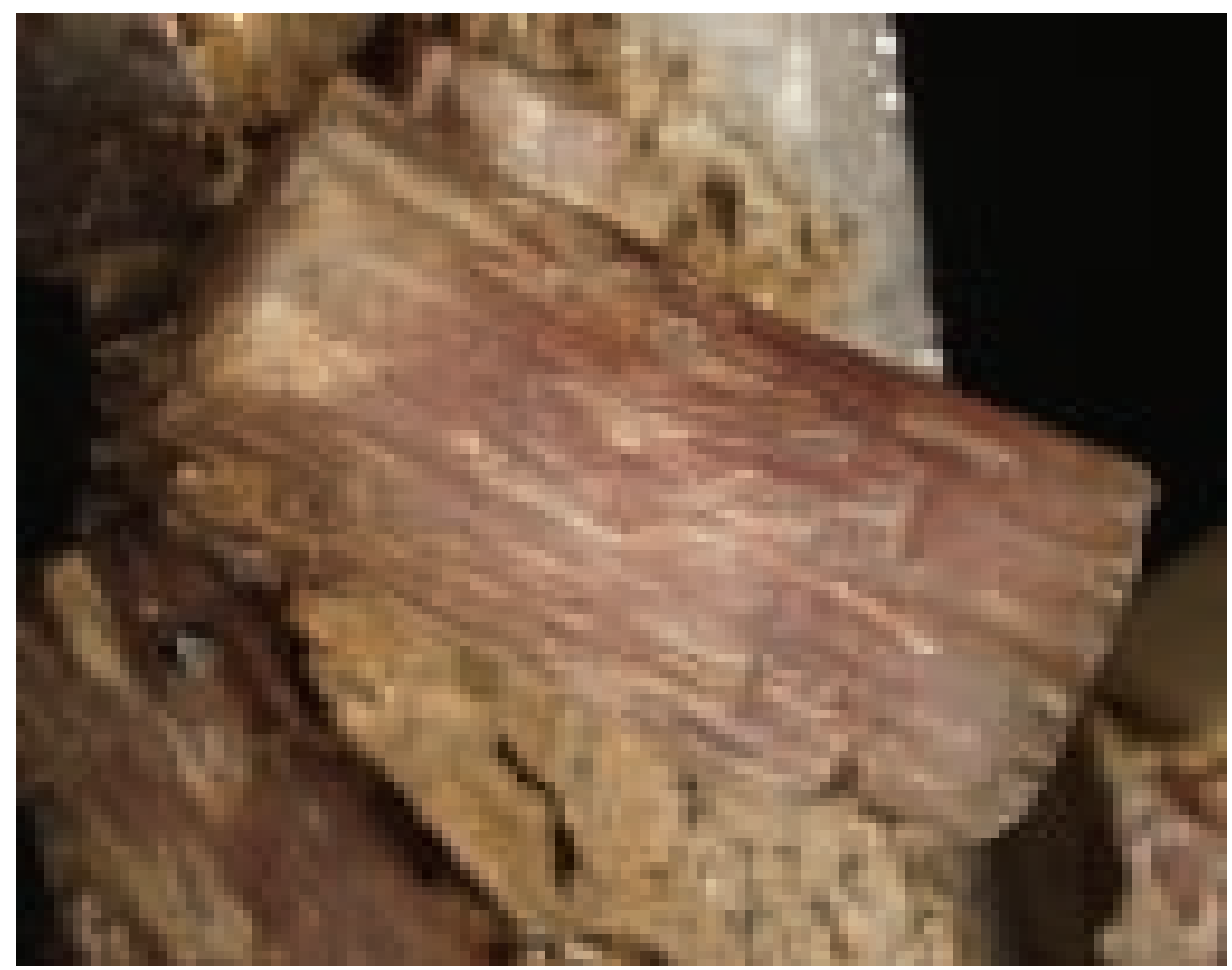

Fig. 31 Fluorapatite crystal, Krásno near Horní Slavkov. Width of photo $1.8 \mathrm{~cm}$; Nicon SMZ1500 microphotography (J. \& E. Sejkora). 
of crystal faces. Rare examples of multicoloured, zoned prismatic crystals were noted. Fluorapatite occured especially in surface outcrops of the Huber stock in quartz veins inside as well as outside the stock. This material was moved to a secondary location to dumps between the Huber quarry and ventilation shaft No. 2. Exceptionally esthetic specimens, carrying pink and violet fluorapatite crystals of $5 \mathrm{~mm}$ size on $10 \mathrm{~cm}$ smoky quartz crystals and accompanied by cassiterite and sulfides, were found in a cavity in the NW forefield area.

Druses of fluorapatite carrying clusters of small crystals cover the cavities in granite, greisen or in marginal pegmatite. A similar type of occurrence in gneisses has a green colour of fluorapatite. This type comes especially from a site at $500 \mathrm{~m}$ a.s.1., in the section of "cave-in reserves". Nice specimens of this type occured at the $X^{\text {th }}$ level of the Schnöd stock or in marginal pegmatite in the NW forefield.

Fluorapatite forms perfectly shaped crystals up to $5 \mathrm{~cm}$ long in mylonitic clay and alteration material of some dislocation zones. The crystals are usually green, grey blue or violet. Cavities and negative imprints after dissolved crystals occurred, sometimes with skeletal fluorapatite remains. The preserved crystals are rather rare and they were collected mainly at upper levels of all exploited stocks or in the Gellnauer quartz veins.

Compact or massive fluorapatite occurs with other phosphate minerals in phosphate-rich accumulations (Sejkora et al. 2006d).
Very young fluorapatite generation (probably supergene) forms finely acicular to fibrous aggregates similar to cotton wool and finely crystalline coatings of white, yellowish, grey, reddish or brown colour on other minerals. This type is known from nearly whole district but it is particularly abundant in the "cave-in reserves" of the Huber stock. Especially fine, colourless or light pink acicular crystals with silky lustre or earthy coatings and infill in coroded older fluorapatite or triplite are characteristic.

\section{Fluorite}

Krejčí (1855), Nowicki (1857), Jantsch (1858), Glückselig (1862), Klvaňa (1886), and numerous other authors reported fluorite occurrence. Fluorite is one of widely distributed minerals at the deposits. It occurs as impregnation in various rocks, it forms veinlets up to several $\mathrm{cm}$ wide, either monomineralic or in association with other minerals. Fluorite colours are varied, but dark violet colour is the most typical (Figs 32-36).

In the Gellnauer vein cluster, fluorite occurs as $4 \mathrm{~cm}$ long octahedra consisting of tiny hexahedral crystals. Similar fluorite (usually light violet and partly transparent) comes from the open pit in the Huber stock and from some quartz veins at the level $500 \mathrm{~m}$ a.s.1., often in association with fluorapatite and other minerals. Quartz veins usually carry violet fluorite hexahedra and yellow crystals are rare. Green fluorite is known from rare oc-

Fig. 32 Zoned fluorite crystals in cavity of quartz gangue, Krásno near Horní Slavkov. Width of photo $1.8 \mathrm{~cm}$; Nicon SMZ1500 microphotography (J. \& E Sejkora).

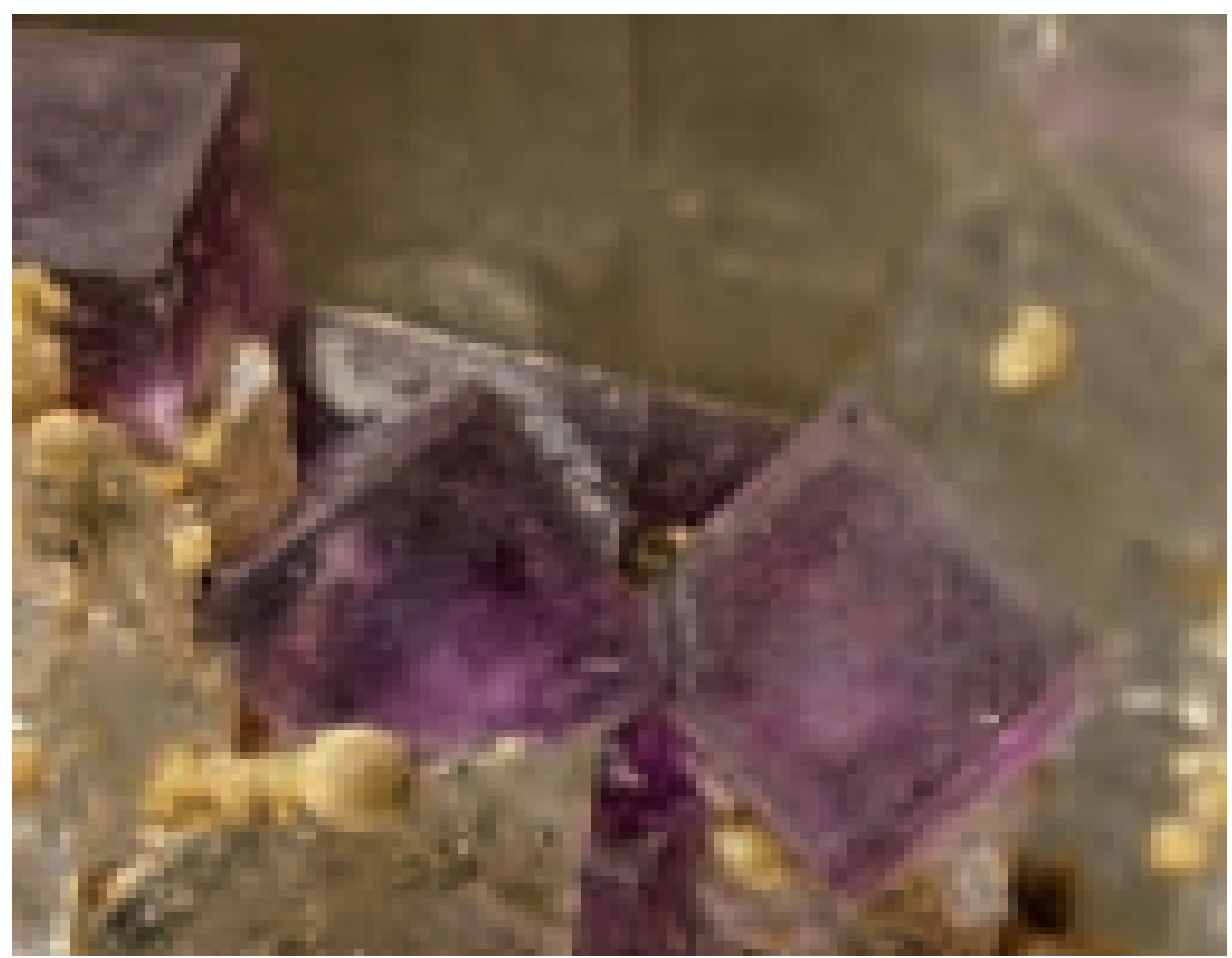




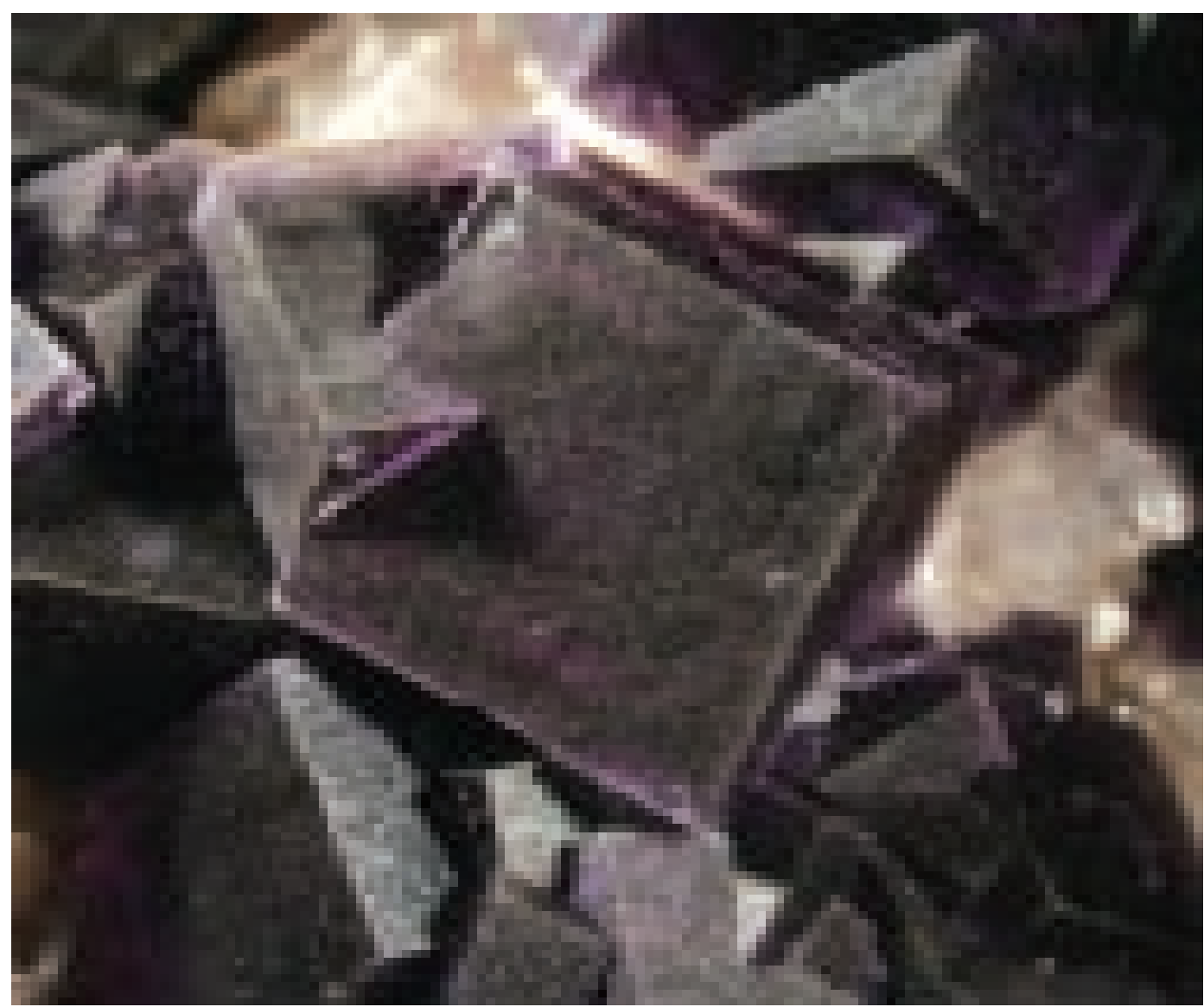

Fig. 33 Group of dark violet fluorite crystals, Krásno near Horní Slavkov. Width of photo $1.8 \mathrm{~cm}$; Nicon SMZ1500 microphotography (J. \& E. Sejkora).

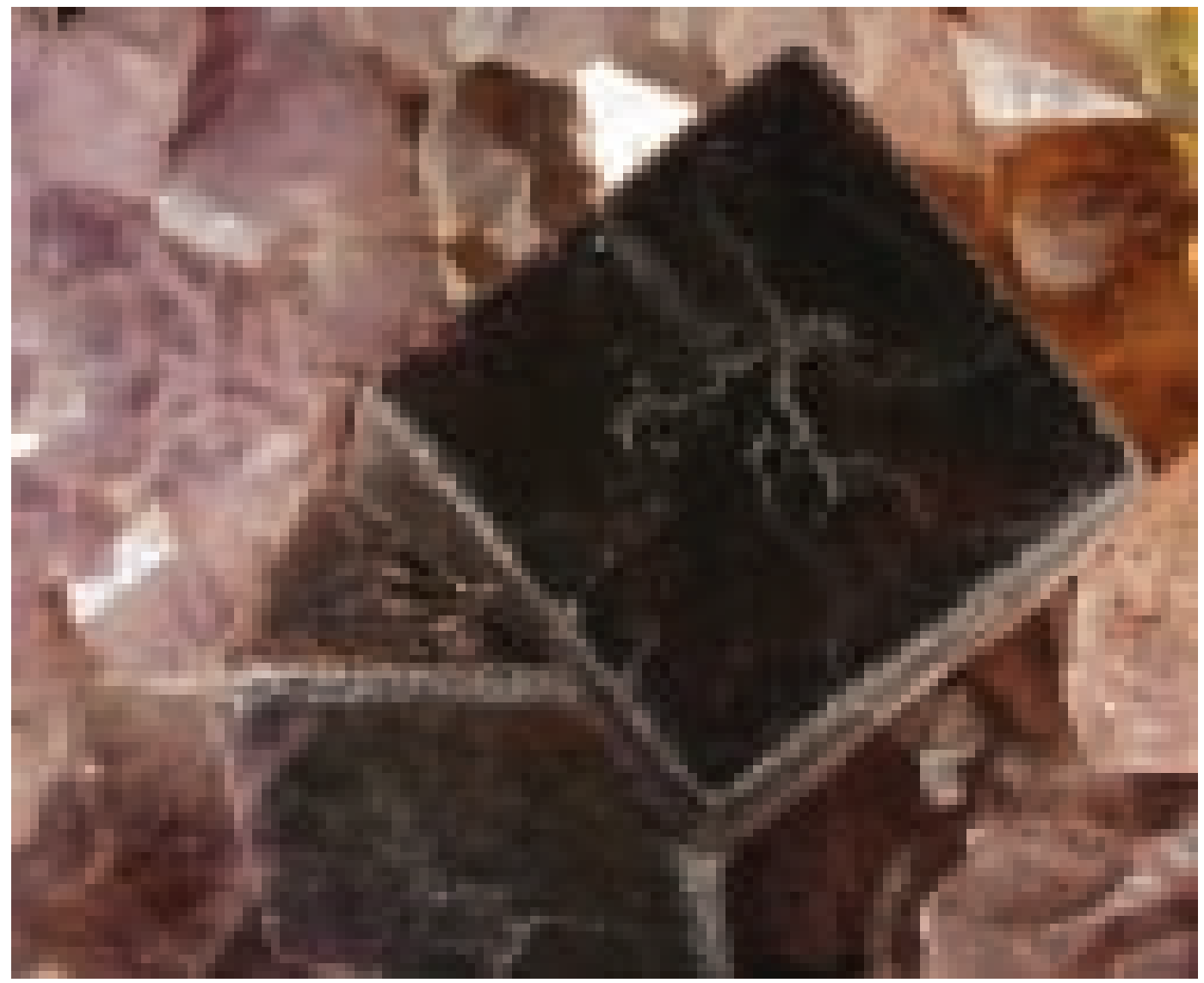

Fig. 34 Dark violet to black fluorite crystals, Krásno near Horní Slavkov. Width of photo 2 cm; Nicon SMZ1500 microphotography (J. \& E. Sejkora). 
Fig. 35 Rare yellow, partly zoned crystals of fluorite on quartz crystals, Krásno near Horní Slavkov. Width of photo $1.2 \mathrm{~cm}$; Nicon SMZ1500 microphotography (J. \& E. Sejkora).

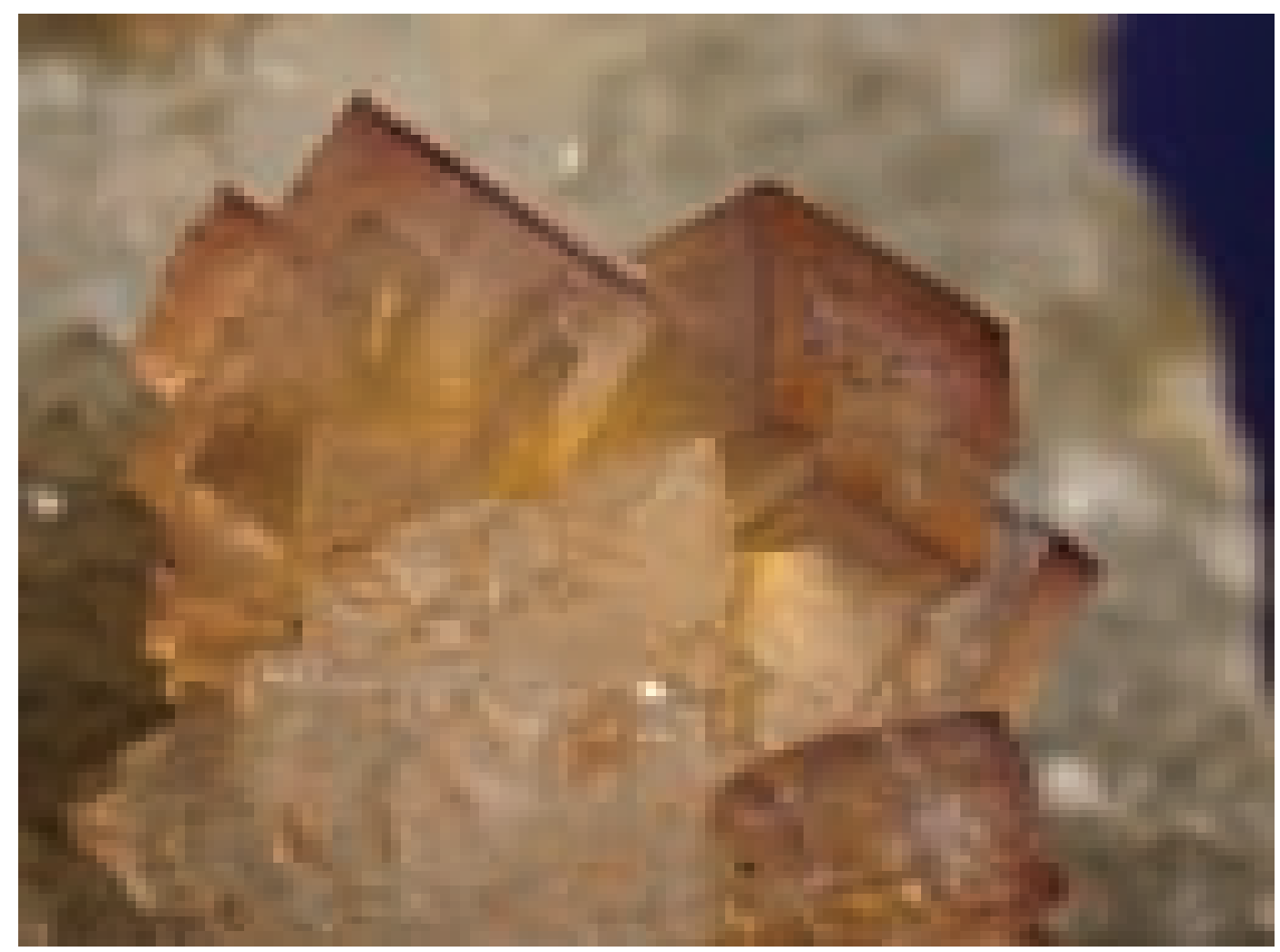

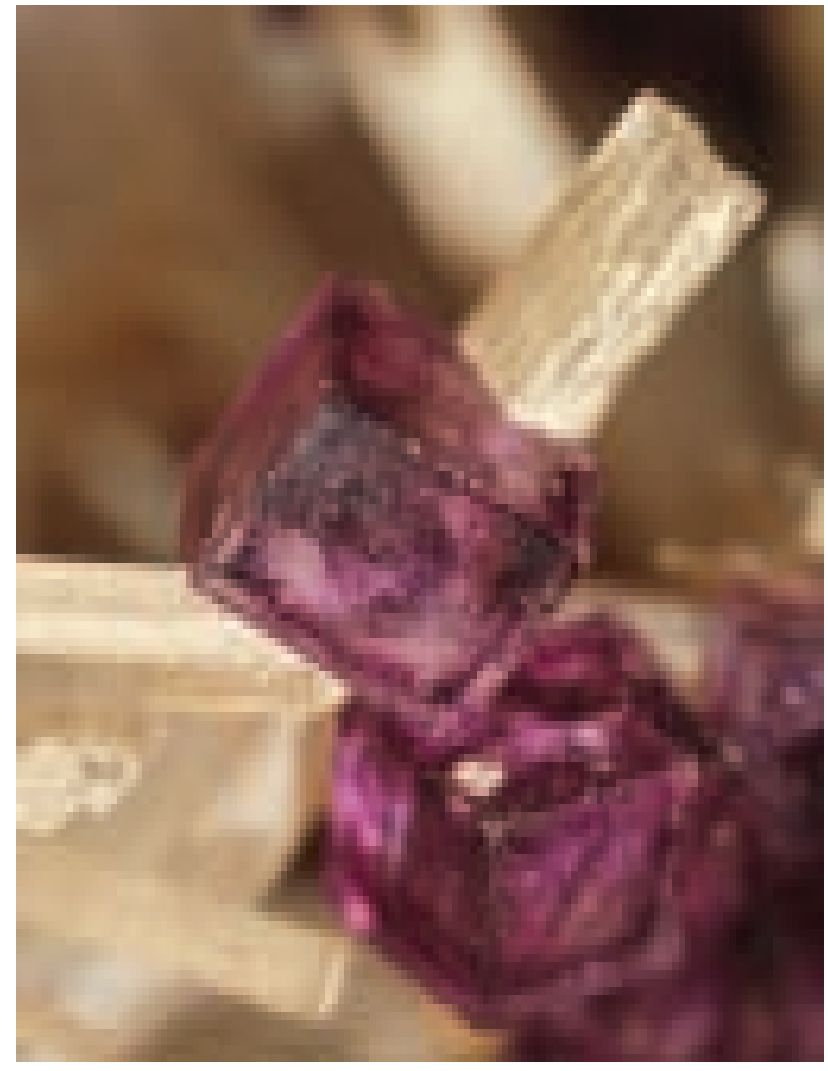

Fig. 36 Fluorite crystal overgrowing white columnar crystals of fluorapatite, Krásno near Horní Slavkov. Width of photo $4 \mathrm{~mm}$; Nicon SMZ1500 microphotography (J. \& E. Sejkora). currence in cavities in quartz at old dumps behind the ventilation shaft No. 2 .

Fluorite hexahedra are exceptionally large to several $\mathrm{cm}$, while crystals up to $1 \mathrm{~cm}$ in size are common. Some cavities in quartz vein at the level of $500 \mathrm{~m}$ a.s.l. carried crystals to $3 \mathrm{~cm}$ sizes. Interesting is the association of black-violet fluorite with zinnwaldite and fluorapatite. A unique sample with individualized acicular carpholite crystals was collected. Also unusual are compact violet fluorite masses with enclosed or intergrown thin needles or radiating aggregates of carpholite (or clay mineral pseudomorphs after carpholite) from the VIII ${ }^{\text {th }}$ level of the Schnöd stock. Specimens with perfect octahedral crystals of violet fluorite about $1 \mathrm{~cm}$ size occurred in vuggy quartz vein from the level of $455 \mathrm{~m}$ a.s.l. Another interesting example from milky white quartz mass at the $5^{\text {th }}$ level of the Huber stock is a fluorite in $1 \mathrm{~cm}$ colourless crystals enclosing $5 \mathrm{~mm}$ hexahedra of dark violet fluorite. At the NW forefield fluorite crystals to $5 \mathrm{~mm}$, associated with clay minerals, show corroded crystal faces.

\section{Hübnerite}

Several old-time mineralogists described this mineral under the obsolate name of megabasite, for the first time in 1869 (Kratochvíl 1957-1964). Hübnerite was very abundant in quartz veins of the Gellnauer cluster as acicular crystals up to $4 \mathrm{~cm}$ long and $4 \mathrm{~mm}$ wide (Figs $37-$ 


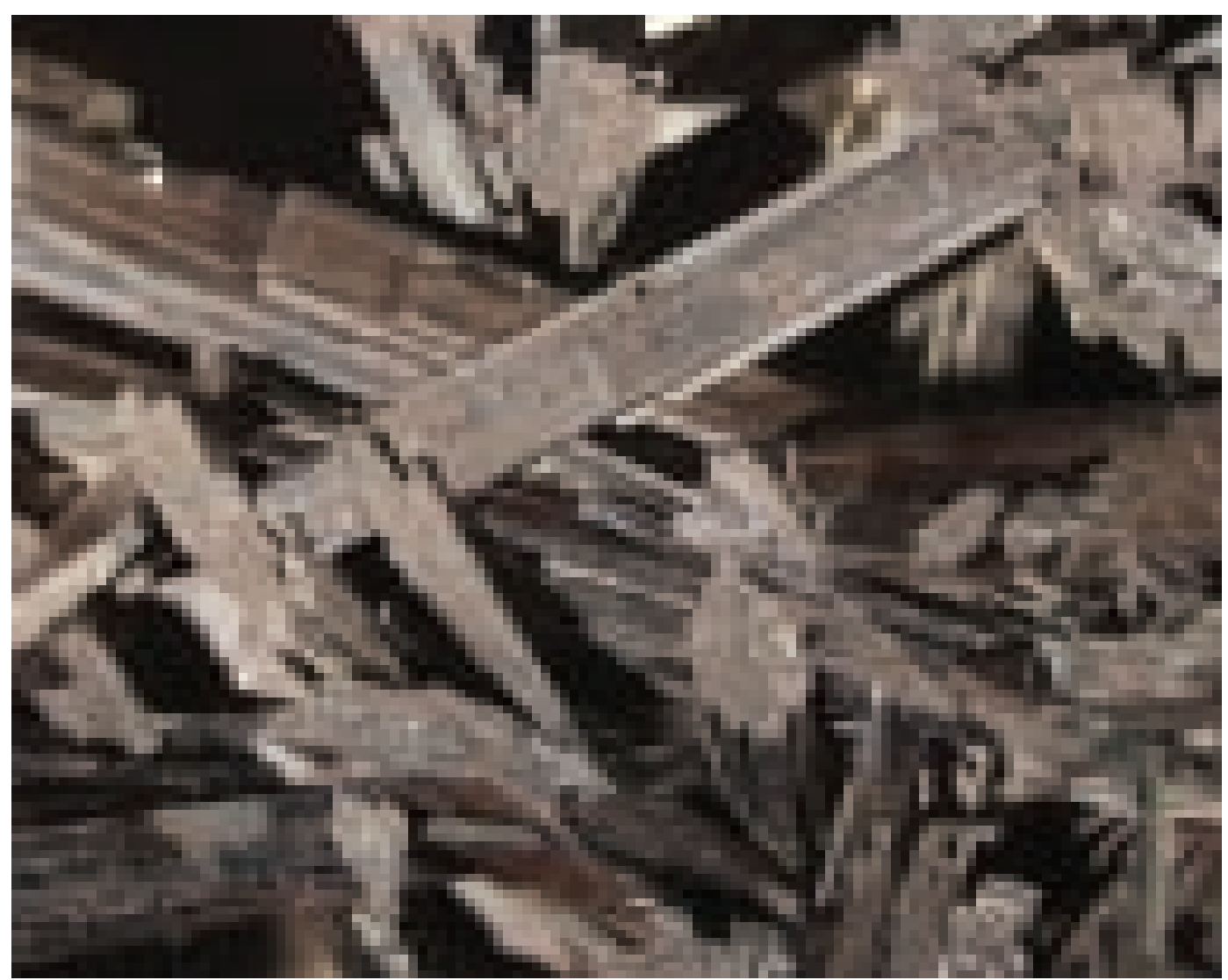

Fig. 37 Group of columnar hübnerite crystals, Krásno near Horní Slavkov. Width of photo $1 \mathrm{~cm}$; Nicon SMZ1500 microphotography (J. \& E. Sejkora).

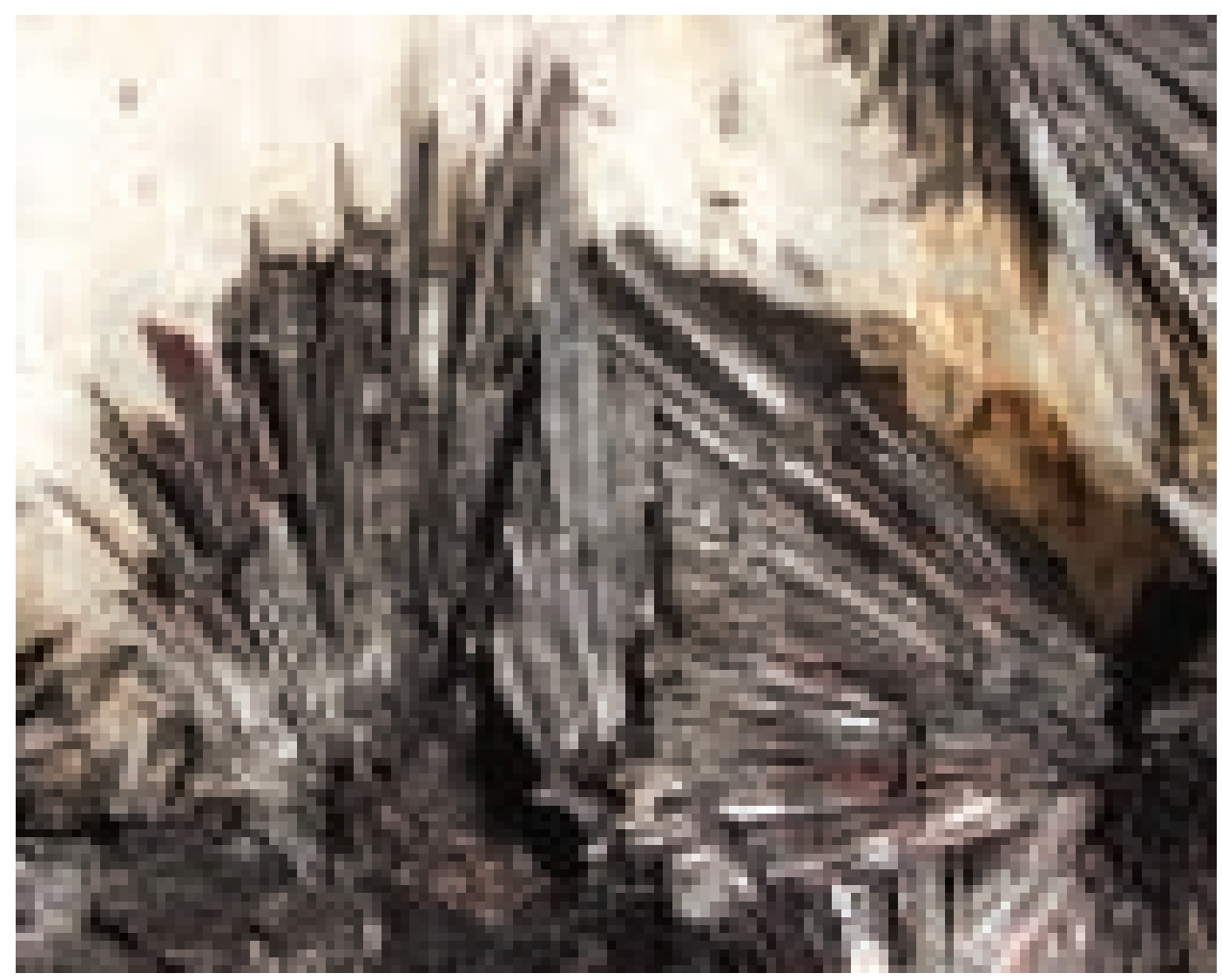

Fig. 38 Group of lathlike hübnerite crystals, Krásno near Horní Slavkov. Width of photo $1.5 \mathrm{~cm}$; Nicon SMZ1500 microphotography (J. \& E. Sejkora). 


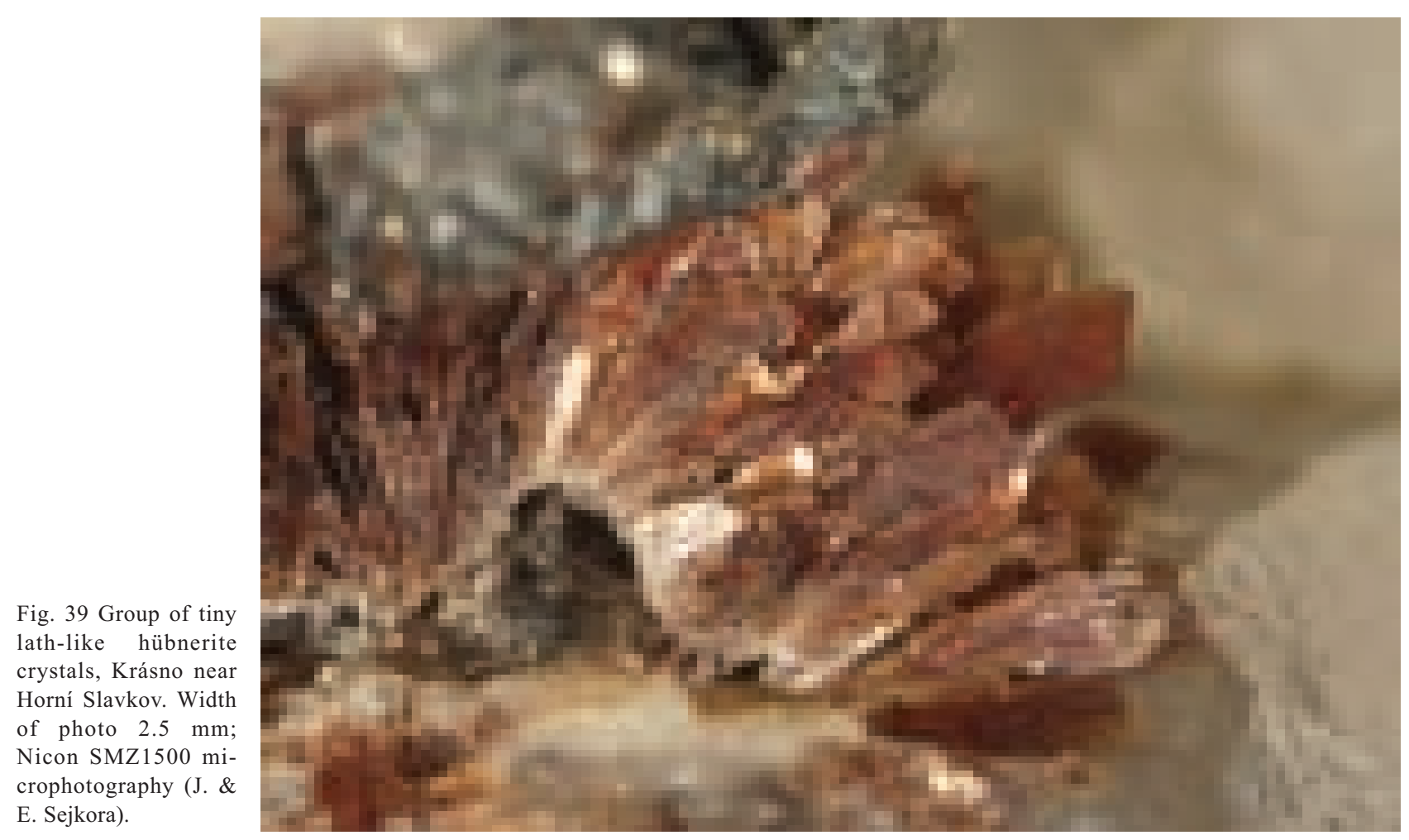

39). The crystals show reddish reflections. Even at present, it is possible to collect similar hübnerite but in small size crystals to $1 \mathrm{~cm}$ on old dumps behind the ventilation shaft No. 2. The mineral occurs in quartz gangue with fluorite, quartz, chalcopyrite, and other less common minerals. Small crystals, rarely to $1 \mathrm{~cm}$, occurred in the Huber open pit.

Hübnerite was common at the level of $500 \mathrm{~m}$ a.s.l. in cavities in quartz in greisen and in quartz veins intersecting the stock. Very interesting and exceptional was a find of perfectly transparent, strong red acicular crystals to $5 \mathrm{~mm}$ from a site near the level of $500 \mathrm{~m}$ a.s.l., adit $\mathrm{CH}$ 4062. Some of the crystals are translucent, of blood-red colour. These specimens can be considered as the purest known (end-member) natural hübnerite. Also interesting is hübnerite occurrence in carpholite veins in association with fluorite, rhodochrosite, apatite, and cassiterite at the VIII $^{\text {th }}$ and $X^{\text {th }}$ levels of the Schnöd stock.

\section{Quartz}

All authors dealing with the district mentioned quartz as the main mineral in ore. Quartz is especially abundant in greisens. White massive quartz is present in quartz veins and quartz bodies (e.g., $3^{\text {rd }}$ and $5^{\text {th }}$ level) up to several $\mathrm{m}$ long. These bodies and some cavities in greisens contain crystals of common milky quatz to $0.5 \mathrm{~m}$. Such cavities occurred at the $5^{\text {th }}$ level of the Huber stock, at the $4^{\text {th }}$ lev$\mathrm{el}$, and the extraordinary level at $500 \mathrm{~m}$ a.s.l. in the former Kaiser shaft area. Similar quartz crystals have been found at oucrops of the Huber stock or at old dumps in sur- roundings. Besides the large crystals, more common are small crystals of about $1 \mathrm{~cm}$ size (Fig. 40), coating cavities or fractured parts of the rocks. In granite stocks and in gneiss, quartz veins carry abundant quartz crystals to $10 \mathrm{~cm}$ sizes.

In addition to common quartz, some coloured varieties occur in the district. Amethyst crystals were observed at the $5^{\text {th }}$ level of the Huber stock and at the $\mathrm{X}^{\text {th }}$ level of the Schnöd stock. Amethyst has been found also at the $4^{\text {th }}$ level of the SE forefield. Citrine crystals to $3 \mathrm{~cm}$ occurred in the open pit at Huber stock. Somewhat more abundant are finds of smoky quartz, up to $15 \mathrm{~cm}$ in size, in particular in the Huber open pit. Best known is a $1.5 \mathrm{~m}$ high cavity at the $4^{\text {th }}$ level of the NW forefield coated by perfectly transparent smoky quartz crystals to $15 \mathrm{~cm}$ sizes. The cavity also yielded perfectly black morion druses with individual crystals reaching $5 \mathrm{~cm}$.

Wax-white chalcedony occurs according to Hoffmann (1903) and Kratochvíl (1963) as one of late deposited minerals. It forms botryoidal aggregates passing sometimes to stalactiform shapes. Colours are usually white, blue or yellow. Chalcedony coats early crystallized minerals such as quartz, fluorite, apatite, chalcopyrite, wolframite, etc.

Jasper has been mentioned without closer identification by some older authors as a monomineralic infilling in numerous veins striking mainly NW-SE to W-E. Recent mining exposed jasper in two veins. The first one crossed the gallery at the $4^{\text {th }}$ level in a central part of the Huber stock. The material is jasper of a bright red colour filling a vein from 15 to $20 \mathrm{~cm}$ wide. A second find 


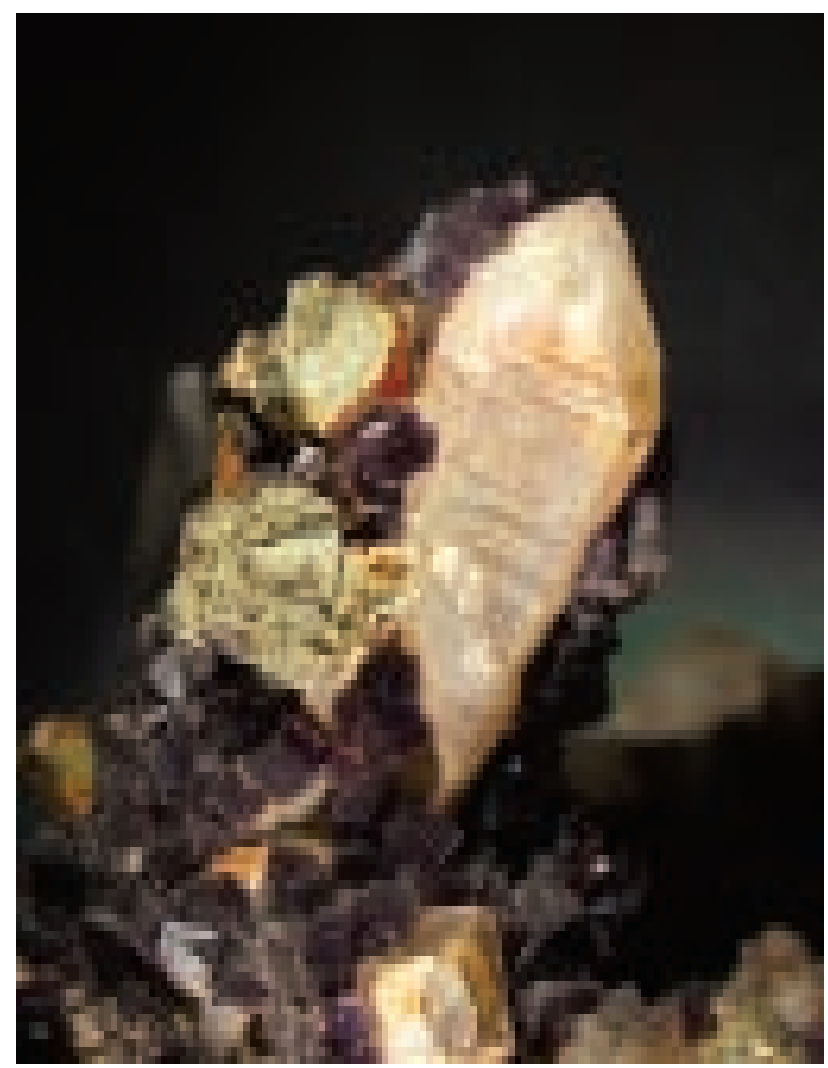

Fig. 40 Quartz crystal overgrown by chalcopyrite and fluorite, Krásno near Horní Slavkov. Width of photo $2 \mathrm{~cm}$; Nicon SMZ1500 microphotography (J. \& E. Sejkora). comes from the $5^{\text {th }}$ level at the same stock, where $10 \mathrm{~cm}$ wide vein of pink jasper was at both sides lined up by quartz crystals locally grading to amethyst.

\section{Molybdenite}

The old information on molybdenite occurrence is provided by Zepharovich (1857), Jantsch (1854), Glückselig (1862), Klvaňa (1886), Krejčí (1855), Jantsch (1858), Katzer (1892), and other authors. Molybdenite is located in pockets of white quartz and in quartz veins. Sometimes, it is dispersed in greisen of the stocks. The largest flakes of molybdenite in the open pit at Huber stock reached up to $5 \mathrm{~cm}$ sizes. Molybdenite crystals (Fig. 41) occur in vuggy quartz in association with fluorite, apatite, emplectite and bismuth. The largest well-formed crystals of a bright silvery colour and perfect metallic lustre reached $1 \mathrm{~cm}$ sizes. At some places, it is covered by a thin oxidation coating and has a mat appearance. Molybdenite was relatively common at dumps from underground mining of quartz veins in proximity of both granite stocks. In underground workings, the largest molybdenite occurrence is known from a level at $455 \mathrm{~m}$ a.s.1. A several $\mathrm{m}$ long block of greisen with a high topaz content carried a strong impregnation of small molybdenite grains. At the NW forefield a tectonic "mirror" several $\mathrm{m}^{2}$ in size consisted of a smeared, $1 \mathrm{~cm}$ thick molybdenite layer with minor tectonic striations.

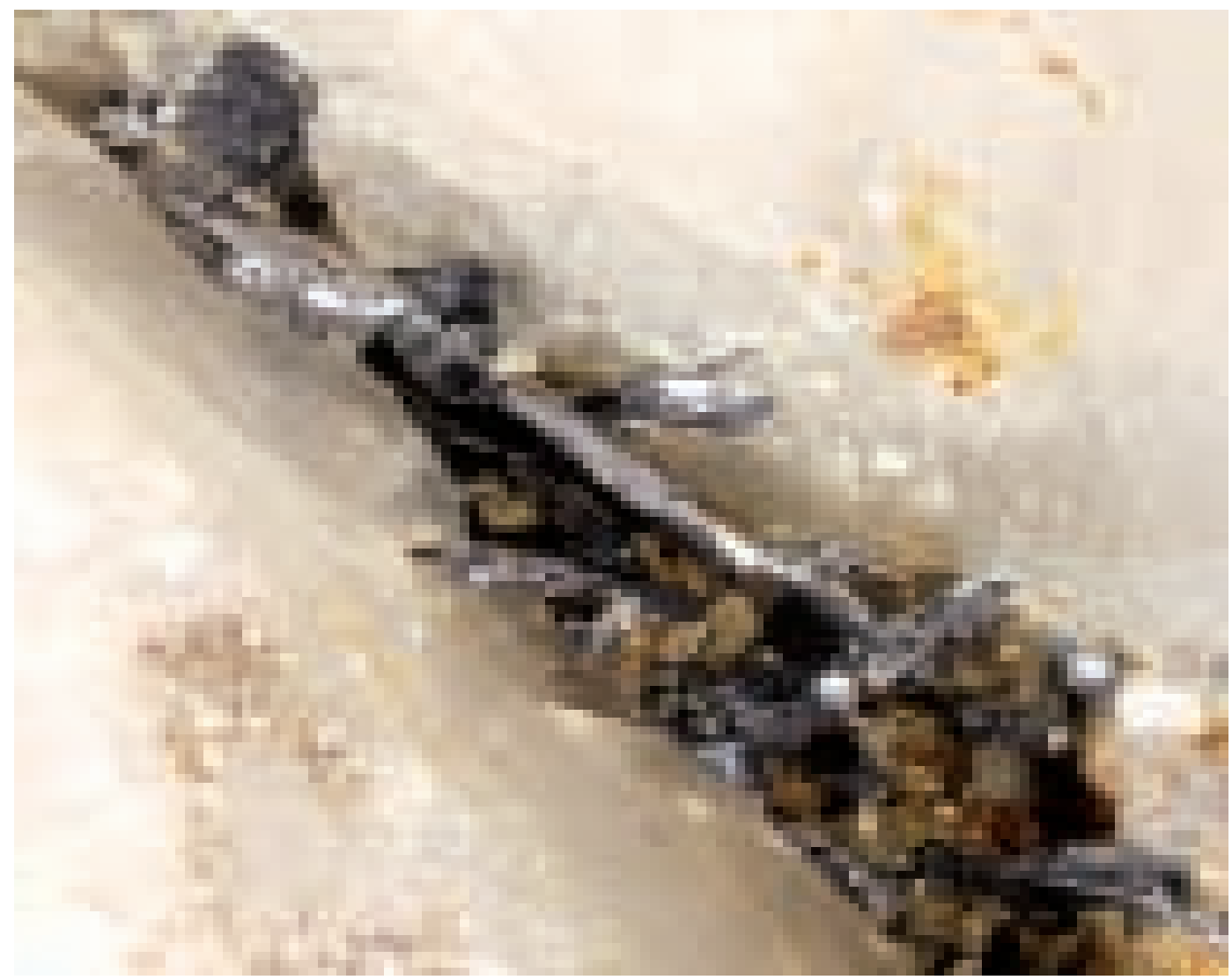

Fig. 41 Molybdenite crystals in cavity of quartz gangue, Krásno near Horní Slavkov. Width of photo $1.3 \mathrm{~cm}$; Nicon SMZ1500 microphotography (J. \& E. Sejkora). 


\section{Rhodochrosite}

Rhodochrosite is the single carbonate relatively widespread in the district. It belongs to the youngest manganese stage of mineralization. In analogy to other manganese minerals, the mineral was more frequent at the Schnöd stock than at the Huber stock. At the latter location, rhodochrosite occurred at the level at $500 \mathrm{~m}$ a.s.1. in the area of "cave-in reserves" as monomineralic aggregates associated with clay minerals. Well-preserved rhodochrosite specimens come from the VIII ${ }^{\text {th }}$ and $\mathrm{X}^{\text {th }}$ level of the Schnöd stock. At the first place it occurred jointly with carpholite and in monomineralic veins. At the second location, it is associated in several places with carpholite, fluorite, clay minerals or it formed monomineralic veins. Rhodochrosite aggregates of bright reddish colour are up to $10 \mathrm{~cm}$ large. In the same area, pink crystals to $1 \mathrm{~cm}$ sizes associated with fluorite and pseudomorphs of clay minerals after carpholite occur. Numerous small finds of rhodochrosite were recorded from the $4^{\text {th }}$ level at the Huber stock.

\section{Scheelite}

Ferber (1774) published an early record of scheelite, followed by Glückselig (1862) and Klvaňa (1886). The oldest specimens of scheelite from Krásno and Horní Slavkov are deposited in the collections of the National Museum

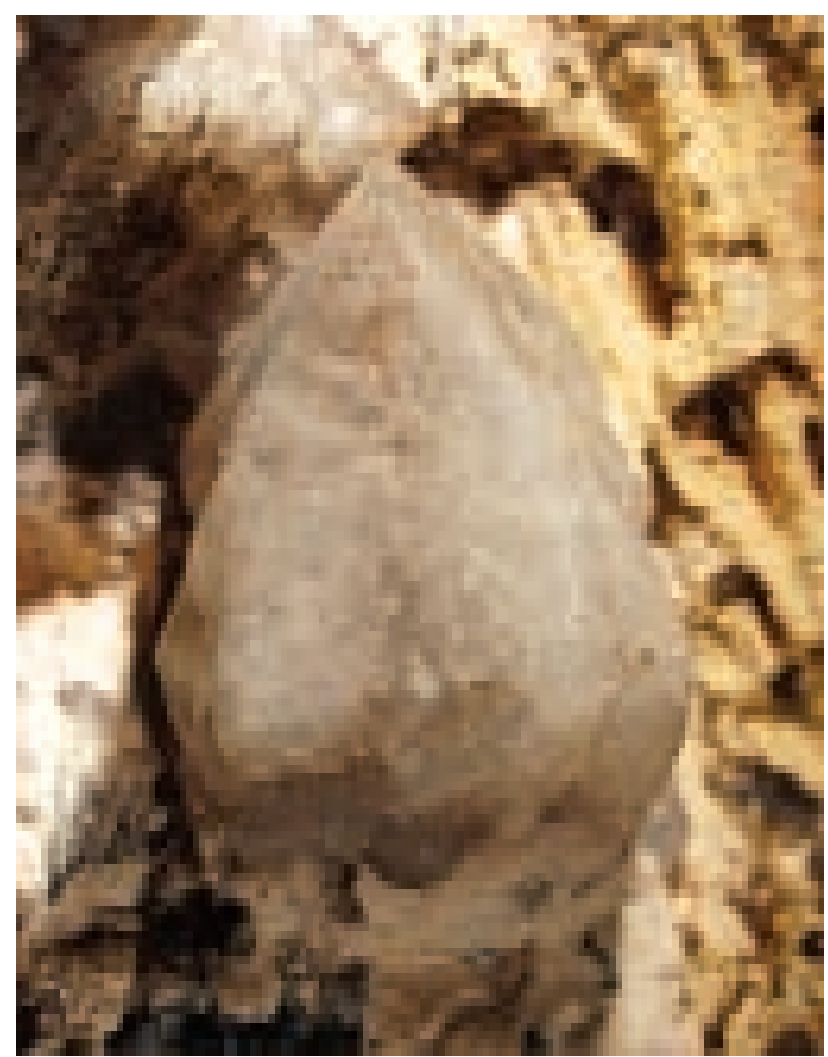

Fig. 42 Scheelite crystal in cavity of quartz gangue, Krásno near Horní Slavkov. Width of photo $1.5 \mathrm{~cm}$; Nicon SMZ1500 microphotography (J. \& E. Sejkora). in Prague (Fig. 42). The largest crystals reach $10 \mathrm{~cm}$ sizes, but their accurate location is unknown. The specimens date from the late $18^{\text {th }}$ and $19^{\text {th }}$ century. This time indicates the Gellnauer set of veins as a probable source. The crystals are usually of white or grey-white colour. Smaller crystals about $1 \mathrm{~cm}$ show brown to honey colour shades.

During the period of mining after 1945, scheelite finds were rather sporadic. A granular scheelite intergrown with quartz occurs at old dumps in proximity of the pub "Kreuzech". The material comes from mining of the Gellnauer veins. Three finds from the late underground mining are documented. The best specimen is a group composed of crystals up to $4 \mathrm{~cm}$ in size from quartz vein at the $4^{\text {th }}$ level of the Huber stock, where it was associated with wolframite and apatite. This scheelite crystal cluster has a fine coating of iron oxides. Additional samples from the same spot carry only a few small scheelite crystals. Most abundant scheelite is recorded at the level of $500 \mathrm{~m}$ a.s.l. in the places of the former Kaiser shaft, where it occurred with sphalerite and chalcopyrite in botryoidal zinnwaldite. New scheelite find comes from ventilation tunnel at the $4^{\text {th }}$ level of the Huber stock. The quartz vein carried anhedral scheelite grains to $5 \mathrm{~cm}$ size and small scheelite crystals to $5 \mathrm{~mm}$ sizes in cavities with wolframite, apatite, sphalerite, chalcopyrite, clay minerals, and some secondary copper minerals including malachite, pseudomalachite and azurite.

\section{Sphalerite}

Glückselig (1862), Sadebeck (1869), Döll (1883), Klvaňa (1886), and others mentioned sphalerite in the Krásno ore district. According to old reports, sphalerite formed striated hexahedra with blunt edges, up to $2-3 \mathrm{~cm}$ in size, in bonanza type of cassiterite accumulations. This type of specimens is preserved in some mineral collections. During the modern mining period this type of sphalerite has not been recorded (Drozen 1965).

Sphalerite is a common mineral in apical parts of both granite stocks. Dark brown to black crystals to $5 \mathrm{~mm}$ have been lately found in the outcrops of the Huber stock in association with other sulfides. Greisen exposed in the cave-in material at the Huber stock shows sphalerite impregnation, which is a feature characteristic also of the Schnöd stock above the VIII ${ }^{\text {th }}$ level. The colours of sphalerite range from black through a bluish black to brown.

\section{Topaz}

Early descriptions of topaz from Horní Slavkov include those by Lindacker (1791), Presl (1837 in Drozen 1969), Gehlička (1858), Groth (1870), and many other mineralogists. Rosický (1916) published a monographic study comparing crystal morphology of topaz from various localities. In addition to paragenetic series introduced by Groth (1870), he brings some new ones. Rosický (1916) documented 27 types of crystal faces plus four addition- 

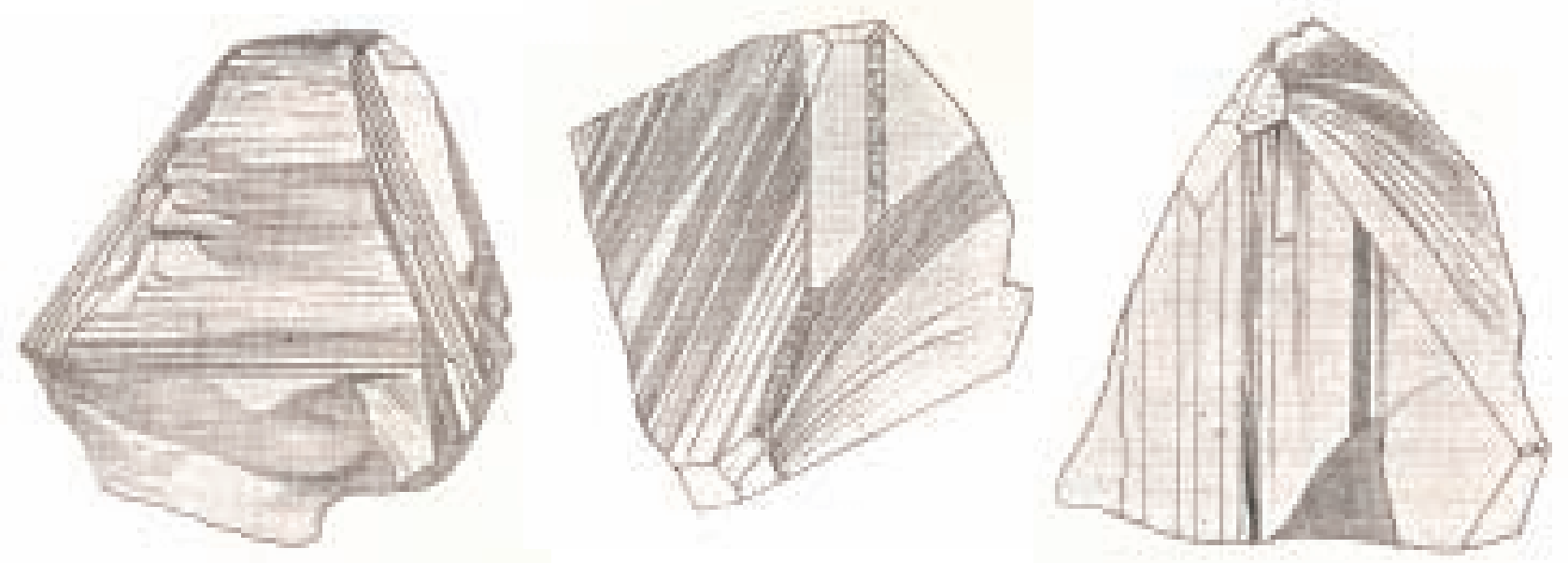

Fig. 43 Drawings of topaz crystals from Krásno near Horní Slavkov (according to Rosický 1916)

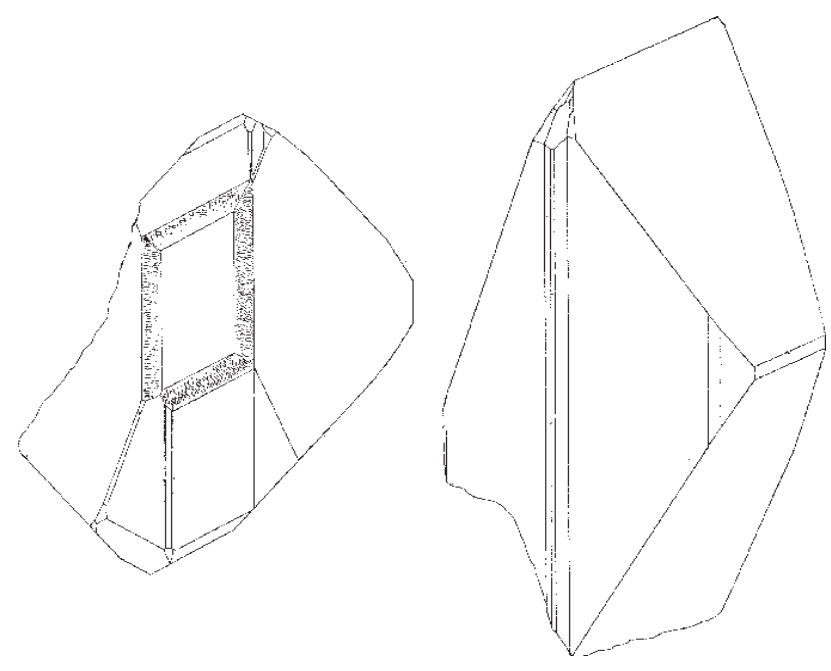

Fig. 44 Drawing of crystal faces of topaz from Krásno near Horní Slavkov (according to Rosický 1916)

al uncertain planes (Figs 43 and 44) on topaz from this district.

Topaz is a characteristic mineral (Figs 45 and 46) in this ore district, associated nearly with all primary minerals at the deposits, from magmatogenic to hydrothermal stages of crystallization. Ever present fluorite indicates abundance of fluorine in the deposit, while the decomposition of feldspars supplied silica and alumina. It was subject to decomposition and replacement by other minerals. Replacement by younger quartz, clay minerals in at least two generations, fluorite, and by cassiterite and sulfides was noted.

The largest accumulations of topaz crystals came from ore pockets or from lenses composed of nearly monomineralic topaz, or of quartz and clay minerals. Such topaz-rich lenses are known from the level at $455 \mathrm{~m}$ a.s.l., where imperfectly crystallized topaz with a mixture of yellow clay minerals forms a body of several $\mathrm{m}$ in size.
Another notable topaz accumulation was found at the $5^{\text {th }}$ level of the Huber mine. Topaz crystallized in mixture of clay minerals together with quartz and apatite crystals. Topaz crystals to $1 \mathrm{~cm}$ sizes have imperfect crystal shapes, are grey, yellowish or yellow green in colour.

There were rare finds of topaz with perfect crystal shapes in the open pit at the Huber stock. This included sky blue crystals to $1 \mathrm{~cm}$ size, fractured honey yellow crystals to $1 \mathrm{~cm}$, and transparent crystals to $5 \mathrm{~mm}$ sizes with a strong glassy to adamantine lustre. The largest crystals found during the recent mining come from a quartz lense at the $\mathrm{X}^{\text {th }}$ level of the Schnöd stock in association with quartz, cassiterite, fluorite, phosphates, and chalcopyrite. The light blue crystals were up to $3 \mathrm{~cm}$ long. Relatively common were monomineralic lenses of fine-grained topaz ("topazite"), e.g, at the levels $500 \mathrm{~m}$ a.s.1., $455 \mathrm{~m}$ a.s.1., and in the NW forefield of the stocks.

\section{Wolframite}

Haidinger (1830), Krejčí (1851), Klvaňa (1886), and other authors reported wolframite from the ore district. Kratochvíl (1963) published an extensive summary of information from old literature. According to study of mesoscopic textures and data from ore microscopy wolframite is the oldest ore mineral. It is black brown or black in colour, has characteristic crystal shapes: tabular, ax-shaped, acicular, and prismatic grains from $\mathrm{mm}$ up to $10 \mathrm{~cm}$ (Fig. 47) or simply massive. Wolframite was replaced by numerous younger minerals including dickite (Drozen 1965). Wolframite was the second economic component after cassiterite but its contents were approximately 10 times lower.

Wolframite crystals from 2 to $5 \mathrm{~cm}$ long in cavities of quartz veins were often collected in the open pit at the Huber stock and in old dumps after mining of quartz veins of the Gellnauer set of veins. The same places yielded wolframite aggregates of $\mathrm{dm}$ dimensions inter- 
Fig. 45 Pale yellow topaz crystals in quartz grangue, Krásno near Horní Slavkov. Width of photo $4.5 \mathrm{~mm}$; Nicon SMZ1500 microphotography (J. \& E. Sejkora).

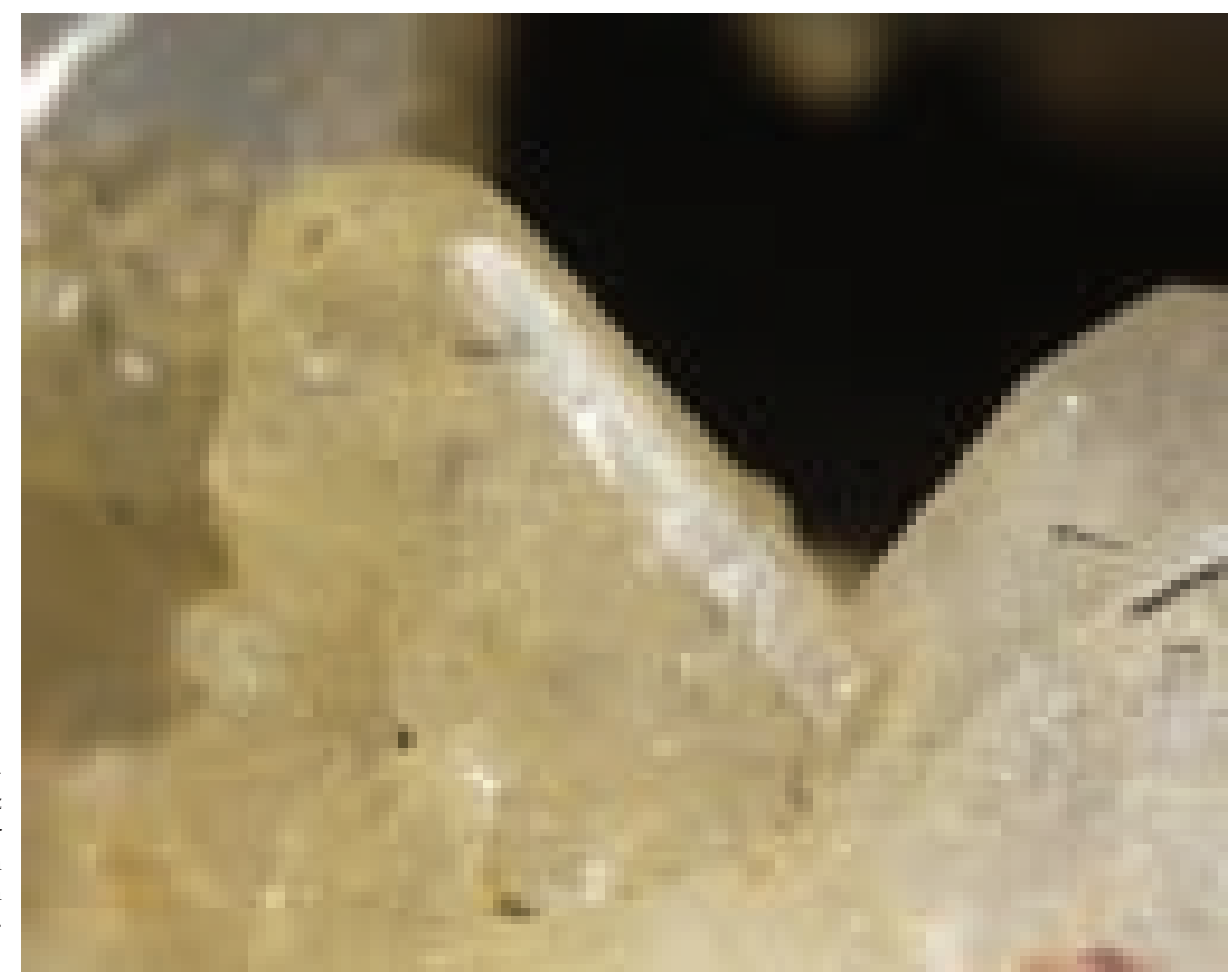

Fig. 46 White topaz crystals in quartz grangue, Krásno near Horní Slavkov. Width of photo $1.8 \mathrm{~cm}$; Nicon SMZ1500 microphotography (J. \& E. Sejkora).

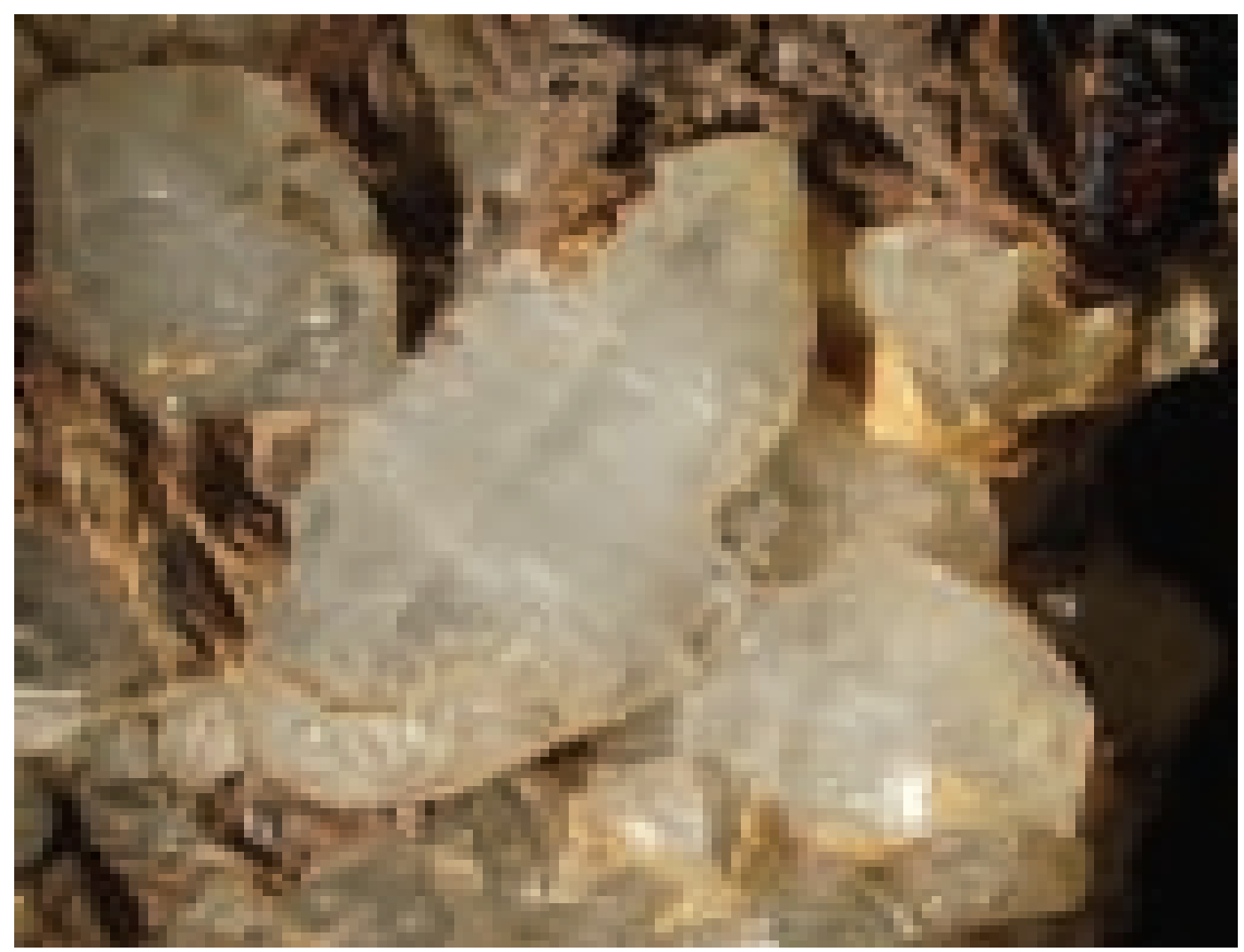




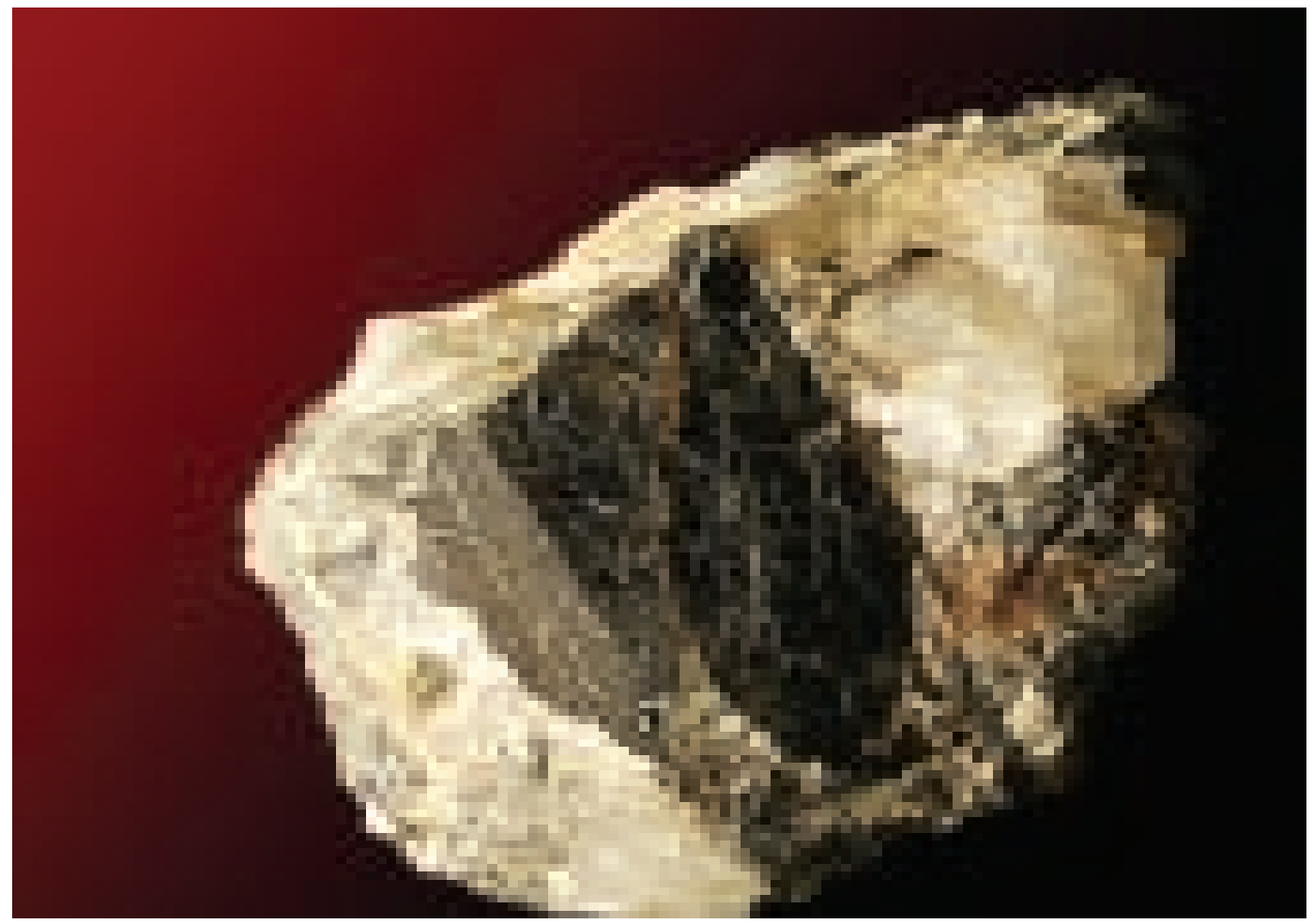

Fig. 47 Prismatic wolframite crystal in quartz gangue, Krásno near Horní Slavkov. Width of photo $10 \mathrm{~cm}$; Canon DS1 macrophotography (J. \& E. Sejkora).

grown in milky quartz. Similar specimens, in part with radiating aggregates of wolframite, came from quartz lenses at the $3^{\text {rd }}$ level of the Huber stock. Wolframite was relatively abundant at the $500 \mathrm{~m}$ level in area of "cavein reserves". Several quartz-wolframite veins carried wolframite crystals to $20 \mathrm{~cm}$ sizes at these places. Unusual topaz-wolframite bonanza accumulations have been encountered at the $5^{\text {th }}$ level of the Huber stock.

\section{Conclusion}

The Krásno ore district carries the largest reserves of tin and tungsten ores in the Slavkovský les region. The ore district comprises several deposits with the classic granite related mineralization in greisens in apical parts of granite cupolas and in their forefield as well as in the veins in the gneiss envelope. As to the level of knowledge, quality and quantity of reserves, the Huber stock is the most important deposit. Exploitation of this deposit early in the $16^{\text {th }}$ century resulted in leading role of its tin in the tin market of Europe, situation, which lasted for some decades. In these respects, the tin ore district reached the status of important mining districts, such as Jáchymov, Př́bram and Kutná Hora in Bohemia. During centuries, numerous specialists in mineral deposits, petrology, mineralogy, hydrogeology, ingeneering geology, geochemistry and other branches of geoscience studied the deposits. As a result, the extensive literature related to this ore district has been published.

Exploitation of these deposits has yielded a large number of rare and exceptional mineral specimens. Carpholite has been described as a new mineral from the Krás- no ore district and numerous mineral species were described as the first occurrence in the Czech Republic. 228 mineral species are known to be present in the district. In this context, the Krásno ore district represents an exceptional mineralogical locality in the Czech Republic, known by its specimens worldwide.

It is noteworthy that various exploration projects in the Krásno ore district brought positive results. However, this qualification relates to practice common in the Soviet block countries during the period of 1960-1989, when the value of some important metals was considered separately from the prices prevalent on the world market. In order to fulfill the expected increase in ore reserves, new potential ore reserves have been measured. Although tin exploitation during the past centuries and up to 1991 mined out large quantities of metal, the Krásno ore district still contains significant quantities of tin and tungsten. Unlike the exhausted deposits of Jáchymov and Př́bram, the Krásno ore district, along with the Cínovec deposit in the Krušné hory, still contain significant potential reserves of $\mathrm{Sn}-\mathrm{W}$ ores in the Czech Republic. The future use of these reserves will depend on tin and tungsten prices on the world market.

Acknowledgements. The present authors gratefuly acknowledge cooperation by Stanislav Vrána, Czech Geological Survey, Prague, Jiří Litochleb and Dalibor Velebil, National Museum, Prague, in preparation of this text. This work was financialy supported by the Ministry of Culture of the Czech Republic (Project MK00002327201).

Submitted July 12, 2006 


\section{References}

Agricola, G. (1556): De re metallica libri XII. - Basilae

Barvír, J. L. (1903): Přehledné zprávy o některých našich místech zlato a stř́ibronosných z poslední čtvrti 16. století. - (Brief reports on gold and silver production in the last quarter of the $16^{\text {th }}$ century). - Horn. hutn. Listy, 4. (in Czech).

Beran, P. (1999): Nerosty cíno-wolframových ložisek Slavkovského lesa. - (Minerals in the tin-tungsten deposits of the Slavkovský les area.) Okresní muzeum a knihovna Sokolov, 287 pp. (in Czech).

Beran, P. - Beranová, V. (1995): Petrologie a mineralogie Sn-W ložisek v oblasti Krásna a Horního Slavkova. - (Petrology and mineralogy of the Sn-W deposits in the Krásno and Horní Slavkov district.) - In: Závěrečná likvidační zpráva závodu Stannum, Rudné doly s.p. Př́ibram, Geofond Praha FZ6630. (in Czech).

Beran, P. - Fikar, M. - Ondruš, P. - ̌̌idkošil, T. - Šrein, V. - Veselovský, F. (1989): Sekundární mineralizace z cíno-wolframového ložiska Horní Slavkov. - (Secondary minerals in the Horní Slavkov tin-tungsten deposit.) - Nepublik. zpr., Rudné doly s.p. Př́ibram, archiv Okr. muz. a knih. Sokolov. (in Czech).

Beran, P. a kol. (2001): Královské horní město Horní Slavkov. - (Horní Slavkov and its history of Royal Mining Town.) - Město Horní Slavkov ve spolupráci s Okresním muzeem Sokolov. (in Czech).

Bernardová, E. - Poubová, M. (1961): Mineralogicko-petrografický posudek vzorků šachta 8 - Horní Slavkov. - (Mineralogical-petrographical report on samples from the shaft No. 8.) - Nepubl. zpráva Geol. průzk. Stříbro, In: Blüml, A. - Tacl, A.: Mineralogickogeochemický rozbor rudního materiálu šachty č. 8 - Horní Slavkov. Geofond Praha P97418. (in Czech).

Bílek, J. (1957): Dějiny dolování v oblasti Horní Slavkov - Krásno, I. Předběžná zpráva o montanistických a geologických poměrech Hubského pně. - (History of mining in the Horní Slavkov - Krásno district, I. Preliminary report on mining and geological situation at the Huber stock.) - Geofond Praha P9253. (in Czech).

- (1958): Zpráva o báňsko-historickém výzkumu Horní Slavkov II. (Report on research of mining and history in Horní Slavkov, part II.) - Geofond Praha P9959 (in Czech).

Breiter, K. - Sokolová, M. - Sokol, A. (1991): Geochemical specialization of the tin-bearing granitoid massifs of NW Bohemia. - Mineral. Deposita, 26: 298-306.

Cornu, F. (1905): Zur Kenntnis des Schlaggenwalder Mineralvorkommens. - Tschermaks mineral. petrogr. Mitt., 24, Wien.

- (1906): Versuche über saure und alkalische Reaktion von Mineralien. - Tschermaks mineral. petrogr. Mitt., 25, Wien.

Döll, E. (1883): Eine neue und einige seltene Pseudomorphosen von neuen Fundorten. - Verh. Geol. Reichsanst., Wien.

Drozen, J. (1965): Výroční zpráva o plnění úkolu “Geologické poměry ložiska Hubský peň za rok 1965“. - (Annual report for 1965, project "Geology of the Huber stock deposit".) - Nepublik. zpr., archiv Rudných dolů s.p. Př́bram. (in Czech).

- (1967): Geologické poměry ložiska Hubský peň, Výroční zpráva za rok 1966. - (Annual report for 1966, project "Geology of the Huber stock deposit”.) - Nepublik. zpr., Rudné doly n.p. Př́ibram, Geofond Praha P22656. (in Czech).

- (1969): Geologické poměry Sn-W ložiska Hubský peň u Krásna nad Teplou (Slavkovský les). - (Geology of the Huber stock Sn-W deposit near Krásno nad Teplou (Slavkovský les area).) - Kandidátská dizertační práce, Geofond Praha P22651. (in Czech).

Erben, B. (1884): O českých nerostech. - (On minerals in Bohemia.) Vesmír, 13: 20. (in Czech).

Ferber, J. J. (1774): Beiträge zu der Mineral - Geschichte von Böhmen. Berlin

Fiala, F. (1948): Stručné vyjádření o ložisku Sn-W rud v Horním Slavkově. - (A brief evaluation of the Horní Slavkov Sn-W deposit.) - Nepubl. zpr., Geofond Praha. (in Czech).

- (1950): Zpráva o geologickém výzkumu rudonosné oblasti ( Sn-W,Cu) u Horního Slavkova a Krásna n. Teplou provedeném v letech 1946-
1950. - (Report on geological research of ore-bearing district (Sn-W, Cu) near Horní Slavkov and Krásno n. Teplou during the period 19461950.) - Nepubl. zpr., Geofond Praha P3310. (in Czech).

- (1952): Zpráva o geologických výzkumech v rudním obvodu u Horního Slavkova a Krásna nad Lesy provedených v roce 1946. (Report on geological research in the Horní Slavkov and Krásno nad Lesy ore district in 1946.) - Nepubl. zpr., Geofond Praha. (in Czech). - (1962): Základní geologický výzkum Císařského (Slavkovského) lesa. Závěrečná zpráva o výzkumném úkolu za léta 1955-1960. - (Geology of the Císařský (Slavkovský) les area. Final report for the 19551960 period.) - Nepubl. zpr., Archiv ČGÚ. Praha. (in Czech).

- (1958): Hlavní typy hornin v širším okolí Pramenů. - (The main rocktypes in the Prameny area.) - Geol. práce, 50; 3-70. Bratislava. (in Czech).

- (1968): Granitoids of the Slavkovský Les Mountains. - Sbor. geol. Věd, Geol., 14, Praha.

Fiala, F. - Pácal, Z. (1961): Zpráva o výzkumu greisenových těles záp. Krásna s výpočtem zásob Sn-Li-Rb rud na ložisku "Koník". - (Report on study of greisen deposits west of Krásno and calculation of Sn-Li-Rb ore reserves at the "Koník" deposit.) - Nepublik. zpr., Geofond Praha FZ4274. (in Czech).

- (1962): Ložisko albitické aplitické žuly záp. Krásna (Císařský les) jako náhradní živcová surovina. Výpočet prognózních zásob. - (Study of albite aplitic granite deposit west of Krásno (Císařský les) as substitute material for feldspars. Calculation of prognosis reserves.) Nepublik. zpr., Geofond. Praha P15345. (in Czech).

- (1968): Aplogranit albitowy na tle surowców skaleniowych Czechoslowacji. - (Albite aplogranite as feldspar raw material in Czechoslovakia.) - Inst. Geol. Biul., 223: 119-154. Varšava. (in Polish).

Fiala, F. - Škvor, V. (1956): Zpráva o ukončení orientačního geologického mapování důlních prostorů šachet č. 11, 15, 17, a štoly č. 13 v Horním Slavkově. - (Report on pilot geological mapping of shafts Nos 11, 15, 17 and adit No. 13 in Horní Slavkov.) - Nepublik. zpr., Geofond Praha P7188. (in Czech).

Fiala, F. et al. (1956): Zpráva o geologických výzkumech v Císařském Lese za rok 1955. - (Annual report on geological research in the Císařský les area in 1955.) - Nepublik. zpr., Geofond Praha P7751. (in Czech).

- (1957): Zpráva o geologických výzkumech v Císařském Lese za rok 1956. - (Annual report on geological research in the Císařský les area in 1956.) - Nepublik. zpr., Geofond Praha P8627. (in Czech).

- (1960): Základní geologický výzkum Císařského (Slavkovského) Lesa (1955-1960). - (Geology of the Císařský (Slavkovský) les area, report for the 1955-1960 period.) - Nepublik. zpr., Geofond Praha. (in Czech).

Frieser, A. (1916): Erzvorksmmen im Kaiserwaldgebirge, Separatabdruck. - Berg - und Hüttenm. Jb., Wien.

Gareiss, A. (1901): Über Pseudomorphosen nach Cordierit. - Tschermaks mineral. petrogr. Mitt., 20, Wien.

Gehlička, P. (1858): Die Gebirgsarten in der Umgebung von Eger. Programm Gymnasium, Eger.

Glückseling, A. M. (1862): Das Vorkommen der Mineralien im Egere Kreise Böhmens. - Versammlung deutscher Naturfor. und Ärzte, Karlsbad.

Groth, P. (1870): Über den Topaz einiger Zinnerzlagerstätten, besonders von Altenberg und Schlaggenwalde. - Z. Dtsch. geol. Gesell., Hannover.

- (1916): Die Lagerstätten - Abteilung der mineralogischen Sammlung des k. bayer. staates in München. - Z. prakt. Geol., 24.

Günther, I. (1820): Zpráva o slavkovském důlním obvodu, Archivní zpráva in Bílek (1959). (Report on the Slavkov mining district), Archival report in Bílek (1959).

Haidinger, W. (1830): Notiz von einer neuen Pseudomorphose. - N. Jr. Miner., Geol., Paleont.

Hašlar, O. (1956): Mineralogický rozbor W-Sn koncentrátu a průměrného technologického vzorku z lokality Krásno n. Teplou. - (Mineralogi- 
cal analysis of W-Sn concentrate and an average technological sample from the locality Krásno n. Teplou.) - Nepublik. zpr., Geofond Praha P14427. (in Czech).

Havelka, J. (1985): Klasifikace ložisek nerostných surovin. - (Classification of mineral deposits.) - Geol. Průzk., 1, Praha. (in Czech).

Heilmaier, J. (1930): Über Zinnerz (Zinnstein) (Formen und Akzessorien). - N. Jb. Geol. Min. Paläont., Beilage, 61, Stuttgart.

Hladká, N. - Jarchovský, T. (1959): Zpráva o výzkumu paragenetických a minerogenních poměrů na slavkovských žilách Sn-W formace a s nimi spojených pneumatolyticko-metasomatických přeměn. Zpráva o geol. výzkumech za rok 1957. - (Report on paragenetic and minerogenic relations of Sn-W veins at Horní Slavkov and the associated pneumatolytic-metasomatic alterations. Annual report for 1957.) - Nepublik. zpr., Geofond Praha. (in Czech).

Hoffmann, J. (1903): Historisch-mineralogische Skizze von Schlaggenwald. - Programm der k. u k. Staatsrealschule in Elbogen 1903, Loket.

- (1904): Radium in Schlaggenwald. - Zeit. prakt. Geol., 12, Berlin.

Hochstetter, F. (1855): Die geologische Verhältnisse von Karlsbad. - Jb. geol. Reichsanst., Wien.

- (1856): Allgemeiner Bericht über die geolog. Aufnahme der I. Section der k. k. geol. Reichanst. in Böhmen im Sommer 1855. - Jb. d. geol. Reichsanst., Wien.

- (1856): Die Verhältnisse des Falkenau - Elbogner Braunkohlenbeckens in Böhmen. - Jb. d. geol. Reichsanst., Wien.

Holubec, J. (1961): Strukturdiskordanz des variszischen und assyntischen Baues im Gebirgssystem von Krušné Hory - Smrčiny (Erzgebirge Fichtelgebirge). - Věst. Ústř. Úst. geol., Praha

Christiansen, E. H. et al. (1983): Petrogenesis of topaz rhyolites from the western United States. - Contrib. Min. Petr., 83: 486-508. Heidelberg.

Janečka, J. (1973): Závěrečná zpráva o geologicko-ložiskovém výzkumu Sn-W ložisek Českého masívu. - (Final report on geological-economic geological research of Sn-W deposits in the Bohemian Massif.) - Nepublik. zpr., archiv Ústř. Úst. geol. Praha. (in Czech).

Jantsch, F. (1853): Über das Vorkommen des Zinnes in Böhmen und die Verhältnisse des Bergbaues von Schlaggenwald. - Jb. d. geol. Reichanst., Wien.

- (1854): Ueber das Vorkommen des Zinnes in Böhmen. - Österr. Z. Berg - u. Hüttenwes., Wien.

- (1858): Einiges über das Vorkommen des Zinnes in Böhmen und über die geognostischen und bergbaulichen Verhältnisse der Zinn Industrie von Schlaggenwald. - Z. d. mont. V. im Erzgebirge.

Jarchovský, T. (1959): Zpráva o mineralogicko-geochemickém výzkumu Sn-W ložiska v Krásně. - (Report on mineralogical-geochemical research of Sn-W deposit at Krásno.) - Nepublik. zpr., Geofond Praha P10289. (in Czech).

- (1962): Mineralogicko-geochemický výzkum Sn-W ložiska v Krásně nad Teplou, část II., Schnödův peň. - (Mineralogical-geochemical research of Krásno nad Teplou Sn-W deposit, part II, Schnöd stock.) - Nepublik. zpr., archiv Ústř. Úst. geol. Praha. (in Czech).

- (1969): Ložiskové poměry Gelnavské žíly v Krásně - (Montanistic situation of the Gelnauer vein at Krásno.) - Sbor. geol. Věd, ložisk. Geol., 10, Praha. (in Czech).

Jarchovský, T. - Pavlů, D. (1980): Geologicko-ložiskový výzkum Slavkovského lesa v letech 1976-1980. - (Geological and enonomicgeological research in the Slavkovský les area, 1976-1980 period.) Nepublik. zpr., archiv Ústř. Úst. geol., Praha. (in Czech).

- (1991): Albite-topaz microgranite from Horní Slavkov (Slavkovský les Mts.), NW Bohemia. - Věst. Ústř. Úst. geol., 66, 13-22. Praha.

Jarchovský, T. - Štemprok, M. (1979): Geochemistry of granites of the Slavkovský les Mts. - Sbor. geol. Věd, ložisk. Geol. Mineral., 20, Praha.

Ježek, B. (1914): Drobné zprávy mineralogické. - (Minor mineralogical reports.) - Čas. Mus. Král. čes., Praha. (in Czech).

- (1932): Mineralogie. - (Mineralogy) - 549-1368, Ústř. naklad. učitel. Českoslov., Praha. (in Czech).

Jokély, J. (1856-1857): Die Erzlagerstätten und Bergbaue im böhmischen Anteile des Erzgebirges. - Jb. d. geol. Reichsant. 1856, Bergwerksfreund 1857, Wien.

- (1857): Zur Kenntnis der geologischen Beschaffenheit des Egerer Kreises in Böhmen. - Jb. d. geol. Reichsant., Wien.
Kachlik, V. (1993): The evidence for Late Variscan nappe thrusting of the Mariánské Lázně Complex over the Saxothuringian terrane (West Bohemia). - J. Czech. Geol. Soc., 38: 43-54. Praha.

Kastl, E. - Tonika, J. (1984): The Mariánské Lázně metaophiolite complex (West Bohemia). - Krystalinikum, 17, 59-76. Praha.

Katzer, F. (1892): Geologie von Böhmen. - pp. 305-309.

Kenngott, A. (1851): Karpholit von Schlaggenwald. - Berichte über die Mittheilungen von Freunden der Naturwissenschaften in Wien, gesammelt und heraragegeben von W. Haidinger, Band VII.

Kettner, R. (1917): Z nejnovějších výzkumů o rudních nalezištích v Čechách. - (Information on the present research of ore deposits in Bohemia.) - Horn. hut. Listy, Praha. (in Czech).

Klvaňa, J. (1886): Nerosty království Českého. - (Minerals of the Kingdom of Bohemia.) - Uherské Hradiště. (in Czech).

Kolektiv (1995): Likvidační zpráva závodu Stannum Horní Slavkov. Report on closure of the Stannum enterprise in Horní Slavkov. Nepublik. zpr., Geomont s.r.o. Př́ibram, Rudné doly s.p. Př́íbram, archiv Rudných dolů s.p. Př́bram. (in Czech).

Konta, J. (1957): Jílové minerály Československa. - (Clay minerals of Czechoslovakia.) - Nakladatelství ČSAV Praha. (in Czech).

Kopecký, L. jun. - Jakeš, P. (1985): Petrografický a geochemický výzkum mariánskolázeňského metabazitového komplexu. - (Petrographical and geochemical research of the Mariánské Lázně metabasite complex.) - Nepublik. zpr., Archiv ÚÚG. Praha. (in Czech).

Korbel, P. (1983): Sekundární minerály ložiska Horní Slavkov. - (Secondary minerals at the Horní Slavkov deposit.) - Diplomová práce, Katedra mineralogie, geochemie a krystalografie Př́r. Fak. Univ. Karl., Praha. (in Czech).

- (1991): Supergene minerals from Horní Slavkov. - Sbor. Nár. Muz. (Praha); B 47: 1-24.

Kovalenko, V. I. et al. (1971): Redkometalnye granitoidy Mongolii. ("Rare-metal"-bearing granitoids of Mongolia.) - Nauka. Moskva. (in Russian).

Kozubek, P. et al. (1985): Závěrečná zpráva Huberův peň - 5. patro, 2. etapa. - (Final report on Huber stock, 5th level, second stage.) Nepublik. zpr., Rudné doly n.p. Příbram, Horní Slavkov, Geofond Praha. (in Czech).

- (1989): Závěrečná zpráva úkolu Krásno sz. předpolí. - (Final report on the project Krásno, northwestern forefront.) - Nepublik. zpr., archiv Rudných dolů s.p. Př́ibram. (in Czech).

Kratochvíl, F. (1960): Zpráva o geologickém mapování v Slavkovském Lese. - (Report on geological mapping in the Slavkovský les area.) Nepublik. zpr., Geofond Praha P13420. (in Czech).

Kratochvil, J. (1957-1964): Topografická mineralogie Čech (A-Ž). [Topographic mineralogy of Bohemia (parts A-Ž).] - Nakladatelství ČSAV Praha. (in Czech).

Krejči, J. (1851): Počátkové nerostopisu jakožto návod k ustanovování nerostů dle př́rodopisných znaků, Díl II. - (Introduction to mineralogy aimed at mineral identification based on physical properties, Part II.) - Praha. (in Czech).

- (1855): O prahorách českých. - (On ancient rock formations in Bohemia.) - Živa, 3, Praha. (in Czech).

Krusch, P. (1916): Die Wolframit - und Zinnerzlagerstätten bei Schönfeld - Schlaggenwald, ein Beispiel des Erzgehaltes austelen der Gänge und alter Halden im Böhmischen Wolframit - Zinnerzgebiet. - Z. prakt. Geol., Berlin - Halle.

Kudielka, E. (1919): Die Zinn und Wolframbergbaue von Schlaggenwald in Böhmen. - Montan.-Rsch., Wien

Kušnír, I. - Jarchovský, T. (1967): Výpočet zásob cínových rud a předběžná zpráva o výzkumu na lokalitě Krásno ve Slavkovském lese. - (Calculation of tin ore reserves and a preliminary report on research at Krásno locality in the Slavkovský les area.) - Nepublik. zpr., Geofond Praha P19915, V56228. (in Czech).

Laube, G. (1876): Geologie des Böhmischen Erzgebirges, I. Geologie des westlichen Erzgebirges oder des Gebirges zwischen Maria Kulm - Schönbach und Joachimsthal - Gottesgab. - Archiv für Landesdurchforschung Bohmens III.

Lindacker, J. T. (1791): Beschreibung einiger Topase, Welche in dem Schlaggenwald Zinnstocke vorkommen. - Sitz. Gesell. W. 
Mach, Z. (1979): Asociace jílových minerálů spjatých s cíno-wolframovým zrudněním v okolí Krásna u Horního Slavkova. - (The association of clay minerals accompanying tin-tungsten mineralization around Krásno near Horní Slavkov.) - Acta Univ. Carol., Geol., 3-4, Praha. (in Czech).

- (1979): Chalkosiderit a Ba - farmakosiderit z Krásna u Horního Slavkova, nálezová zpráva. - (Chalcosiderite and Ba-pharmacosiderite from Krásno near Horní Slavkov, preliminary report.) - Čas. Mineral. Geol., Praha. (in Czech).

Mach, Z. - Korbel, P. (1990): Sekundární minerály z Huberova pně u Krásna u Horního Slavkova. - (Secondary minerals from the Huber stock at Krásno near Horní Slavkov.) - Př́roda Karlovarska I., Karlovarské muzeum v Karlových Varech. (in Czech).

Majer, J. (1970): Těžba cínu ve Slavkovském lese v 16. století. - (Tin mining in the Slavkovský les area in the $16^{\text {th }}$ century.) - Národní technické muzeum Praha. (in Czech).

Majer, J. - Jangl, L. (1995): Vývoj hornictví cínu ve Slavkovském lese od 13. do 20. století. - (History of tin mining in the Slavkovský les area between the $13^{\text {th }}$ and $20^{\text {th }}$ century.) - In: Závěrečná likvidační zpráva závodu Stannum. - Nepubl. zpráv., Rudné doly s.p. Př́íbram, Geofond Praha FZ6630. (in Czech).

Mrázek, Z. (1981): Crandalit a mixit z Horního Slavkova. - (Crandallite and mixite from Horní Slavkov.) - Sbor. Vys. šk. chem. techn., G 20, Praha. (in Czech).

Najman, K. (1990): Krásno - Horní Slavkov, č. úkolu 2979 2107. (Krásno - Horní Slavkov, Report on Project No. 2979 2107.) Nepubl. zpráva, Geoindustria Praha, Geofond Praha P75709. (in Czech).

Neužilová, M. - Vejnar, Z. (1963): Geologie a petrogeneze krystalických břidlic severozápadní části Slavkovského lesa. - (Geology and petrogenesis of metamorphic rocks in the nortwestern part of the Slavkovský les area.) - Sbor. Ústř. Úst. geol., G, 28: 87-106. Praha. (in Czech).

Novák, L. (1988): Vertikální opakování intruzívních fází v krudumském granitovém masívu. Slavkovský les. - (The vertical repetion of intrusion phases in the Krudum granite massif. Slavkovský les area.) Sbor. Západočes. Muz. Přír., 67: 68-73. Plzeň. (in Czech).

Nowicki, C. von (1857): Das Vorkommen des Zinnsteines Schlaggenwald und Schönfeld, Ein Beitrag zur Kenntnis von diesen Lagerstätten. Lotos, 7, Praha.

Pácal, Z. - Pavlů. D. (1972): Nové poznatky o ložisku sodnodraselných živců Vysoký kámen u Krásna. - (New data on the deposit of sodium-potassium feldspars at Vysoký Kámen near Krásno.) - Geol. Průzk., 14: 357-360. Praha. (in Czech).

- (1979): Závěrečná zpráva dílčího úkolu 4/09-4 za léta 1976-1979 živcové suroviny Krásno. - (Final report on the project No. 4/09-4 for the period 1976-1979 - feldspar raw material Krásno.) - Nepubl. zpráva, Geofond. Praha P29587. (in Czech).

Peithner, J. (1780): Versuch über die natürliche und politische Geschichte der böhmischen und mährischen Bergwerke, Wien.

Peschel, J. (1805): Archivní zpráva. - (Archival report) in J. Bílek (1959).

Plášil, J. -Sejkora, J. -Ondruš, P. - Veselovský, F. Beran, P. - Goliáš, V. (2006): Supergene minerals in the Horní Slavkov uranium ore district, Czech Republic. - Journ. Czech Geol. Soc., 51: 149-158

Pleinerová - Hladká, N. (1960): Příspěvek k petrogenezi krystalinika pláště karlovarského masívu v oblasti Císařského lesa. - (A contribution to petrogenesis of metamorphic mantle of the Karlovy Vary pluton in the Císařský les area.) - Čas. Min. Geol., 5: 28-37. Praha. (in Czech).

Polák, L. et al. (1969): Výpočet zásob Krásno - žula, živcová surovina. Etapa předběžná. - (Calculation of reserves at Krásno - granite, feldspar raw material. Preliminary stage.) - Nepubl. zpráva, RD Př́ibram. (in Czech).

Polanský, J. - Racková, H. - Štovíčková, N. (1973): Detailní gravimetrické mapování 1:25 000 Slavkovský les se zahrnutím části chebské a sokolovské pánve. - (Detailed gravity mapping 1:25 000 in the Slavkovský les area and parts of the Cheb and Sokolov basins.) Nepubl. zpráva, Geofond. Praha P24917. (in Czech).

Reuss, A. E. (1854): Kurze Übersicht der geol. Verhältnisse Böhmens, Praha.
- (1863): Geognostische Skizze der Umgebungen von Carlsbad, Marienbad und Francensbad, Praha.

Reyer, E. (1880): Granit und Schiefer von Schlaggenwald. - Jahrbuch der k. k. geol. Reichsanst.

- (1881): Geologie des Zinnes. - Österrichische Zeitschrift für Berg und Hüttenwesen, Wien

Röhlich, P. - Štovíčková, N. (1968): Die Tiefenstörungstektonik und deren Entwicklung im zentralen Teil der Böhmischen Masse. - Geologie 17: 670-694. Berlin.

Rosický, V. (1916): Topaz ze Slavkova v Čechách. - (Topaz from Slavkov in Bohemia.) - Rozpr. Čes. Akad., Vědy Sloves. Umění, Tř. II., 25: 7, Praha. (in Czech).

Rücker, A. (1864a): Zinnerzvorkommen von Schlaggenwald Verhandlungen der k. k. geologischen Reichsanstalt, 14: 1.

- (1864b): Beitrag zur Kenntniss des Zinnerzverkommens bei Schlaggenwald. - Jahrbuch der k. k. geologischen Reichsanstalt, 14, Wien.

Sadebeck, A. (1869): Über die Krystallformen der Blende. - Zeitschrift der deutschen geologischen Gesellschaft, 21.

Sejkora, J. - Ondruš, P. - Fikar, M. - Veselovský, F. - Mach, Z. Gabašová, A. (2006a): New data on mineralogy of the Vysoký Kámen deposits near Krásno, Slavkovský les area, Czech Republic. - Journ. Czech Geol. Soc., 51: 43-55

Sejkora, J. - Ondruš, P. - Fikar, M. - Veselovský, F. - Mach, Z. Gabašová, A. - Škoda, R. - Beran, P. (2006b): Supergene minerals at the Huber stock and Schnöd stock deposits, Krásno ore district, the Slavkovský les area, Czech Republic. - Journ. Czech Geol. Soc., 51: 57-101

Sejkora, J. - Škoda, R. - Ondruš, P. - Beran, P. - Süsser, C. (2006c): Mineralogy of phosphate accumulations in the Huber stock, Krásno ore district, Slavkovský les area, Czech Republic. - Journ. Czech Geol. Soc., 51: 103-147

Sejkora, J. - Škoda, R. - Ondruš, P. (2006d): New naturally occurring mineral phases from the Krásno - Horní Slavkov area, western Bohemia, Czech Republic. - Journ. Czech Geol. Soc., 51: 159-188

Slavik, F. (1903): Nové nálezy minerálů u Slavkova. - (New mineral finds near Slavkov.) - Rozpr. Čes. Akad., Vědy Sloves. Umění, Tř. II., 12: 35, Praha. (in Czech).

Smirnov, V. I. (1983): Geologie ložisek nerostných surovin. - (Geology of mineral deposits.) - SNTL - Nakladatelství technické literatury, Praha. (in Czech).

Stark, M. (1913): Gebirgsgranit und Erzgebirgsagranit in Kaiserwald nebst einigen Bemerkungen über ihne Kontaktprodukte. - Mitt. d. naturwiss. Vereins and. Univ. Wien, 11, Wien

Štědrá, V. (1996): Retrograde evolution of the Mariánské Lázně Complex basic rocks - final report of the project 205/94/1455 of the Czech Grant Agency. - MS Archive Czech Geological Survey Prague, 129 p.

Štědrá, V. (2003): Pre-Carboniferous metamorphic history recorded by metabasites of the Mariánské Lázně Complex, Western Bohemia. Journ. Czech Geol. Soc., 48/1-2, 117-118.

Štědrá, V. - Kachlik, V. - Kryza, R. (2002): Coronitic metagabbros of the Mariánské Lázně Complex and Teplá Crystalline Unit: inferences for the tectonometamorphic evolution of the western margin of the TepláBarrandian Unit, Bohemian Massif. - Geol. Soc. Spec. Publ., London, 201, 217-236.

Strunz, H. (1957): Ferrokarpholit-Karpholit. - Acta Cryst. 10, Copenhagen. Svoboda, J. et al. (1964): Regionální geologie ČSSR, Díl I., sv. I. - (Regional geology of ČSSR, Part I, vol. I.) - Naklad. ČSAV, Praha. (in Czech).

Štemprok, M. (1959): Vznik metasomatických obrub bismutinu kolem vizmutu z rudní oblasti Horního Slavkova. - (Metasomatic rims of bismuthinite around native bismuth in the Horní Slavkov ore district.). - Čas. Miner. Geol., 4; 424-441. (in Czech).

Štemprok, M. (1985): Vertical extent of greisen mineralization in the Krušné hory Erzgebirge granite pluton of central Europe. - Sbor. konf. High heat production granites. St. Austel.

- (1986): Petrology and geochemistry of the Czechoslovak part of the Krušné hory Mts. granite pluton. - Sbor geol. Věd., Ložisk. geol. Mineral., 27, Praha. 
Štovícková, N. (1971): Hlubinná zlomová tektonika Českého masívu. (Deep fault tectonics of the Bohemian Massif.) - Přír. fak. KU. Praha. (in Czech).

Tacl, A. - Blüml, A. (1961): Mineralogicko - geochemický rozbor rudního materiálu šachty č. 8 - Horní Slavkov. - (Mineralogical-geochemical analysis of ore samples from the shaft No. 8 - Horní Slavkov.) Nepubl. zpráva, archiv Rudných dolů s.p. Př́ibram. (in Czech).

- (1974): Mineralogický výzkum sekundárních nerostů ložiska Krásno. - (Mineralogical research of secondary minerals from the Krásno deposit.) - Nepublik. zpr., archiv Rudných dolů s.p. Příbram.

Teuscher, E. O. (1934): Die Stellung des Eibenstocker Granits. - Z. d. deutsch. geol. Ges., Berlin.

- (1936): Umwandlungserscheinungen an Gesteinen des Granitmassivs von Eibenstock - Neudeck. - Mitt. Inst. Mineral. Univ. Leipzig, No 361., Mineral. Petrogr. Mitt., 47.

- (1936): Primäre Bildungen des granitischen Magmas und seiner Restlösungen im Massiv von Eibenstock - Neudeck, Mineral. Petrogr. Mitt., 47.

Timmermann, H. - Štědrá, V. - Gerdes, A. - Noble, S. R. - Parrish, R. R. - Dörr, W. (2004): The problem of dating high-pressure metamorphism: a U-Pb isotope and geochemical study on eclogites and related rocks of the Mariánské Lázně Complex, Czech Republic. - Journal of Petrology 45, 1311-1338.

Vondrová, N. (1962): Závěrečná zpráva o geologickém výzkumu v severovýchodní části Slavkovského lesa. - (Final report on geological research in the northeastern part of the Slavkovský les area.) Nepublik. zpr., Geofond Praha P13966. (in Czech).

Vtělenský, J. (1955): Mineralogický rozbor koncentrátu z Krásna n. Teplou. - (Mineralogical analysis of ore concentrate from
Krásno n. Teplou.) - Nepublik. zpr., Geofond Praha P14426. (in Czech).

Woldřich, J. (1905): Geologie se zvláštním zřetelem na země koruny české, Díl 3. - (Geology with special emphasy on the countries of the Kingdom of Bohemia.). (in Czech).

Zemánek, V. - Gregorová, M. (1959): Dílčí zpráva o geologických výzkumech v okolí Horního Slavkova, provedených v roce 1958. (Report on geological research around Horní Slavkov, conducted in 1958.) - Nepublik. zpr., Geofond Praha P10184. (in Czech).

Zepharovich, V. (1857): Mineralogisches Lexikon für das Kaiserthum Österreich, Wien.

- (1864): Referat in Verhandlungen der k. u. k. geol. Reichsanst, Wien.

Zikmund, J. (1983): Strukturně-tektonické schéma Slavkovského lesa. (Structural-tectonic scheme of the Slavkovský les area.) - Nepublik. zpr., Archiv ČGÚ. Praha. (in Czech).

Zippe, F. X. M. (1847): Allgemeine Übersicht der physikalischen und statistichen Vehältnisse des Elbogner Kreises, In Sommer C. G. (1847) Das Königreich Böhmen, sv. XV. - Elbogner Kreis.

Zoubek, V. (1947): Zpráva o geolog. výzkumech a mapování ve střední části jv. svahu Krušných hor. - (Report on geological research and mapping of the central part of the southeastern slope of the Krušné hory Mts.) - Věst. geol. Úst., 22: 2-3. (in Czech).

- (1951): Předběžná zpráva o geologickém výzkumu a mapování oblasti karlovarského plutonu. - (Preliminary report on geological research and mapping in the Karlovy Vary pluton area.) - Věst. Ústr. Úst. geol., 26, Praha. (in Czech).

Zoubek, V. et al. (1963): Vysvětlivky k přehledné geologické mapě ČSSR 1:200000 M-33-XIII Karlovy Vary. - (Explanation to geological map of CSSR 1:200 000, sheet M-33-XIII Karlovy Vary.) - Praha. (in Czech).

\section{Sn-W rudní revír Krásno u Horního Slavkova - historie těžby, geologická a mineralogická charakteristika}

Sn-W rudní revír Krásno u Horního Slavkova (Slavkovský les, západní Čechy) patř́i k nejvýznamnějším oblastem těžby rud v České republice. Současně vzhledem k zastoupení jednotlivých minerálních druhů a jejich celkovému počtu je výjimečným mineralogickým fenoménem a jednou z nejvýznamnějších mineralogických lokalit světa. V práci je podán přehledný pohled na historii těžby, geologickou situaci revíru, charakteristiku a přehled jednotlivých dílčích ložisek. Lokality v oblasti Horního Slavkova - Krásna byly známy jako bohatý zdroj kvalitních minerálních vzorků, které jsou obsaženy v řadě muzejních kolekcí celé Evropy. Historické muzejní vzorky pocházející z této oblasti jsou obvykle uváděny pod původními názvy lokalit Schlaggenwald (= Horní Slavkov) a Schönfeld (= Krásno). Součástí práce je proto i historie geologických a mineralogických výzkumu a přehled nejvýznamnějších výskytů ,klasických“ minerálních druhů tohoto revíru: arsenopyritu, fluorapatitu, fluoritu, hübneritu, chalkopyritu, karfolitu, kasiteritu, křemene, molybdenitu, rodochrositu, sfaleritu, scheelitu, topazu a wolframitu. 